UNIVERSIDADE DE SÃO PAULO

FACULDADE DE FILOSOFIA, LETRAS E CIÊNCIAS HUMANAS

DEPARTAMENTO DE LINGUÍSTICA

CLARISSA FERREIRA MONTEIRO

\title{
Building Stories e a poética experimental: um olhar semiótico sobre o quadrinho de Chris Ware
}

Versão corrigida

São Paulo 


\title{
Building Stories e a poética experimental: um olhar semiótico sobre o quadrinho de Chris Ware
}

\author{
Versão corrigida
}

Dissertação apresentada ao Programa de Pós-Graduação em Semiótica e Linguística Geral do Departamento de Linguística da Faculdade de Filosofia, Letras e Ciências Humanas da Universidade de São Paulo para a obtenção do título de Mestre em Linguística.

Área de Concentração: Linguística e Semiótica

Orientador: Prof. Dr. Antonio Vicente Seraphim Pietroforte

São Paulo 
Autorizo a reprodução e divulgação total ou parcial deste trabalho, por qualquer meio convencional ou eletrônico, para fins de estudo e pesquisa, desde que citada a fonte.

Catalogação na Publicação

Serviço de Biblioteca e Documentação

Faculdade de Filosofia, Letras e Ciências Humanas da Universidade de São Paulo

Monteiro, Clarissa F.

M772b Building Stories e a poética experimental: um olhar semiótico sobre o quadrinho de Chris Ware / Clarissa F. Monteiro; orientador Antonio Vicente Seraphim Pietroforte. - São Paulo, 2017. $133 \mathrm{f}$.

Dissertação (Mestrado) - Faculdade de Filosofia, Letras e Ciências Humanas da Universidade de São Paulo. Departamento de Linguística. Área de concentração: Semiótica e Lingüística Geral.

1. poética. 2. semiótica. 3. histórias em quadrinhos. 4. experimentalismo 5. narrativa gráfica. I. Pietroforte, Antonio Vicente Seraphim, orient. II. Título. 
Nome: MONTEIRO, Clarissa Ferreira

Título: Building Stories e a poética experimental: um olhar semiótico sobre o quadrinho de Chris Ware

Dissertação apresentada ao Programa de Pós-Graduação em Semiótica e Linguística Geral do Departamento de Linguística da Faculdade de Filosofia, Letras e Ciências Humanas da Universidade de São Paulo para a obtenção do título de Mestre em Linguística.

Aprovada em: 18/01/2018

\section{Banca examinadora:}

Prof. Dr.:

Instituição:

Julgamento:

Assinatura:

Prof. Dr.:

Instituição:

Julgamento:

Assinatura:

Prof. Dr.:

Instituição:

Julgamento:

Assinatura: 


\section{AGRADECIMENTOS}

À minha família, em especial à minha irmã e melhor amiga Cinthia, pelo apoio e incentivo à minha pesquisa.

Ao André, companheiro durante toda a jornada.

Ao professor Antonio Vicente Pietroforte, por acreditar no meu trabalho, pelos ensinamentos e a amizade.

Aos professores do departamento de semiótica, Waldir Beividas e Luiz Tatit, cujas aulas contribuíram para a minha formação e a elaboração desta dissertação.

Ao grupo do GEPOEX: Rodrigo, Maria Vitória, Tati, Laís, Valéria, Matheus e Josuel, pela companhia, amizade e auxílio durante meu percurso acadêmico.

Aos meus colegas de semiótica, Nathália, Carolina Lemos, Guilherme, Thiago, pela generosidade com que me acolheram.

À Daniela, Beatriz e Gabriela, três pessoas que me ensinam muito e cuja amizade é um dos pontos altos dessa jornada.

À Faculdade de Filosofia, Letras e Ciências Humanas da Universidade de São Paulo, por me acolher nestes dois anos de pós-graduação.

À Coordenação de Aperfeiçoamento de Pessoal de Nível Superior (CAPES), pela bolsa concedida para a produção deste trabalho. 
Escrever e desenhar são pensar. Somos ensinados na escola que essas são técnicas, mas eles estão errados.

Desenhar é uma forma de pensar.

Chris Ware 


\section{RESUMO}

MONTEIRO, Clarissa Ferreira. Building Stories e a poética experimental: um olhar semiótico sobre o quadrinho de Chris Ware. 133 f. Dissertação (Mestrado) - Faculdade de Filosofia, Letras e Ciências Humanas, Universidade de São Paulo, 2017.

Esta dissertação tem por objetivo analisar a poética do quadrinho experimental, tendo como corpus principal a obra Building Stories, do quadrinista norte-americano Chris Ware. Building Stories é composto por quatorze impressos, de diferentes formatos e tamanhos. Não é apresentada uma ordem de leitura, permitindo ao leitor escolher seu caminho livremente (dentro das 87 bilhões de combinações possíveis). A primeira parte da pesquisa ocupa-se de fazer um recorte diacrônico que contextualize a obra de Ware, mostrando movimentos de ruptura do quadrinho norte-americano, a partir dos underground comix de 1960-70. Dentre as diversas vertentes surgidas do underground, destaca-se o alternativo ao qual pertencem nomes como Art Spiegelman, Richard McGuire e Chris Ware. A consideração das características do quadrinho alternativo permitem mostrar algumas das singularidades da narrativa gráfica experimental e como Ware se coloca em relação a essa produção. Se faz necessário também apresentar o trabalho de Ware, seu percurso como quadrinista e as características de sua criação, exploradas também nas histórias analisadas nesta dissertação. A segunda parte da pesquisa faz um recorte de duas das quatorze histórias contidas em Building Stories, para análise. A seleção visa apresentar a obra de Ware, mostrando narrativas gráficas que apresentam algumas de suas principais características e a poética dessas narrativas. As análises se utilizam (i) da teoria greimasiana sobre o texto, observando o percurso gerativo do sentido; (ii) a teoria dos sistemas semissimbólicos, a partir dos estudos de Jean-Marie Floch e Antonio Vicente Pietroforte sobre o texto sincrético dos quadrinhos e (iii) a teoria zilberbergiana, naquilo que concerne a missividade e o ritmo. Por meio da aplicação desses três modelos teóricos, busca-se fazer uma análise abrangente dos quadrinhos de Ware, mostrando a complexidade de suas narrativas, nas quais a estrutura formal do quadrinho faz uma proposta de leitura alternativa. A terceira parte, por fim, se debruça sobre a estrutura de Building Stories, estabelecendo um paralelo entre as múltiplas combinações possíveis de histórias e o conceito saussuriano de relação sintagmática. A subversão da leitura linear (presente nas narrativas gráficas convencionais) permite que se percorra o quadrinho por diversos caminhos, a partir de diferentes "pontos de partida": a identidade dos personagens é construída a cada texto escolhido.

Palavras-chave: poética, semiótica, história em quadrinhos, experimentalismo, narrativa gráfica 


\begin{abstract}
MONTEIRO, Clarissa Ferreira. Building Stories and the experimental poetic: a semiotic look upon the comics of Chris Ware. $133 \mathrm{f}$. Dissertação (Mestrado) - Faculdade de Filosofia, Letras e Ciências Humanas, Universidade de São Paulo, 2017.
\end{abstract}

This dissertation aims to analyze the poetics of the experimental comic, presents as main corpus the oeuvre Building Stories, by North American comic author Chris Ware. Building Stories consists of fourteen prints, of different shapes and sizes. A reading order is not suggested, allowing the readers to freely choose their own path (within its 87 billion possible combinations). The first part of this research makes a diachronic clipping that contextualizes Ware's work, presenting the rupture movements of American comics, starting from the underground comix of the 1960s and 70s. Among the varieties of non-mainstream comics that came after the underground, alternative comics are highlighted, featuring names such as Art Spiegelman, Richard McGuire and Chris Ware. A consideration of the characteristics of alternative comics shows some of the singularities of the experimental graphic narrative and how Ware's comics stand in relation to this form of production. It is also necessary to present Ware's work, his course as a comics author and the characteristics of his creations, explored also in the stories analyzed in this dissertation. The second part of the research selects two of the fourteen prints in Building Stories, for further analysis. The selection aims to present Ware's oeuvre, showing graphic narratives that feature some of its characteristics and their poetic qualities. The analysis makes use of (i) the Greimasian theory of text, following the generative course of meaning; (ii) the theory of semi-symbolic systems, based on the studies of Jean-Marie Floch and Antonio Vicente Pietroforte on the syncretic text of comics and (iii) the Zilberbergian theory, in regards to missivity and rhythm. Through the application of these theoretical models, it is sought to make a comprehensive analysis of Ware's comics, showing the formal complexity of his narratives, in which the formal structure of the comic proposes an alternative form of reading. The third part, lastly, focuses on the structure of Building Stories, establishing a parallel between its multiple possible combinations and the Saussurian concept of syntagmatic relation. The subversion of the linear reading (featured in conventional graphic narratives) allows the reader to follow different paths in the comic, from different "starting points": the identity of its characters is constructed with each chosen text.

Keywords: poetics, semiotics, comics, experimentalism, graphic narrative 


\section{SUMÁRIO}

INTRODUÇÃO 10

1. O QUADRINHO EXPERIMENTAL - DO UNDERGROUND A CHRIS WARE ...... 15

1.1 A herança do quadrinho experimental - um recorte diacrônico ....................................... 16

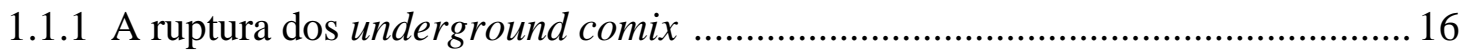

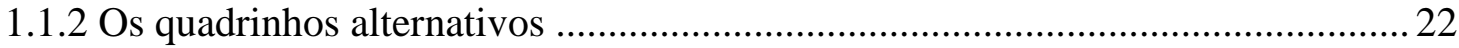

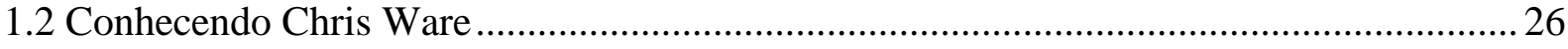

2. A LEITURA ALTERNATIVA - ANÁLISE DE HISTÓRIAS INDIVIDUAIS ........... 36

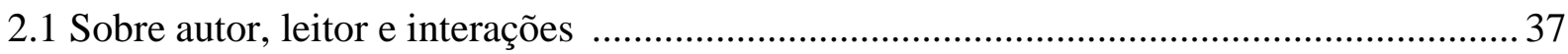

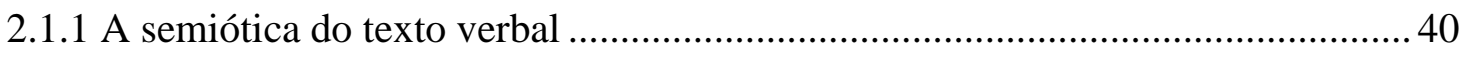

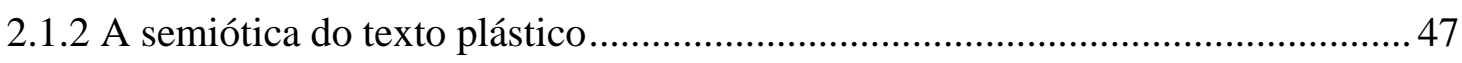

2.1.3 Uma segunda categoria semântica: vida vs. morte .......................................... 50

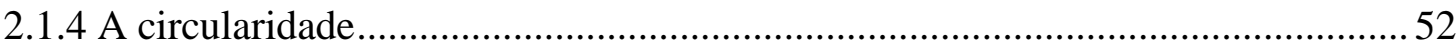

2.2 Segunda análise: a disposição diagramática da narrativa ............................................... 56

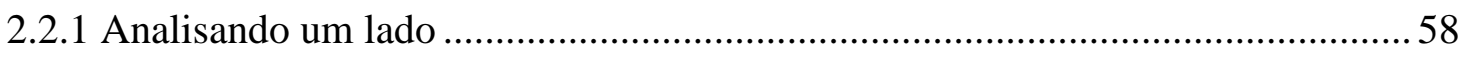

2.2.1.1 As categorias topológica e eidética .....................................................6 66

2.2.2 O outro lado: analisando a segunda história ................................................. 73

2.2.3 O paralelismo e a superposição como síntese da narrativa................................. 81

2.3 Uma consideração sobre tempo em Building Stories .................................................... 84

3. BUILDING STORIES E A NARRATIVA FRAGMENTADA ................................. 91

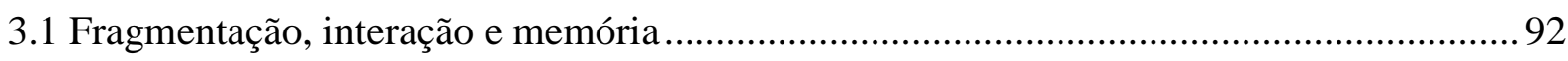


3.2 Fragmentação e combinação 99

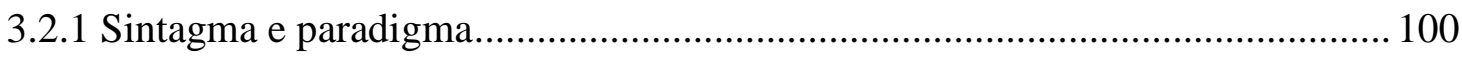

3.2.2 A relação sintagmática em Building Stories .................................................. 101

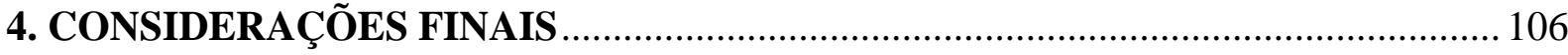

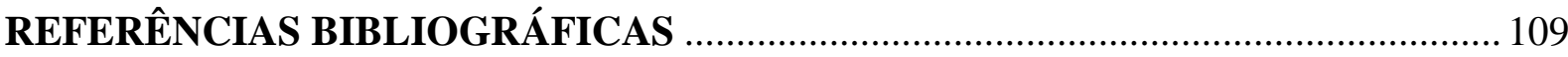

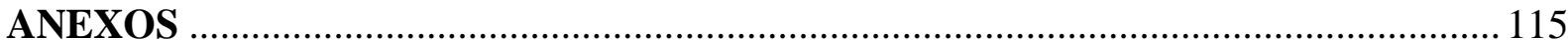


INTRODUÇÃO 
O presente trabalho encontra-se na área de estudos linguísticos, utilizando como metodologia de pesquisa a Semiótica. Os estudos semióticos em quadrinhos (sejam aqueles a partir de Peirce ou da Escola de Paris) datam de longo tempo e desenvolvem-se largamente nas universidades dentro e fora do Brasil. As pesquisas existentes permitem observar os diversos caminhos possíveis para a semiótica aplicada a esse objeto de estudo: a análise do texto, as relações estabelecidas entre elementos plásticos e verbais, a questão do ritmo da narrativa, as relações entre enunciador e enunciatário e tantas outras. Tomando como princípio que "numerosos traços poéticos pertencem não apenas à ciência da linguagem, mas a toda a teoria dos signos, quer dizer, à semiótica geral" (JAKOBSON, 2015, p. 152), o estudo semiótico das histórias em quadrinhos permite ir além da análise da narrativa, com a exploração de seus traços poéticos. O presente trabalho pretende fazer, pois, a sua contribuição aos estudos semióticos sobre a narrativa gráfica, explorando a poética experimental de Building Stories, de Chris Ware. Tal exploração da obra terá como pontos de partida teóricos a teoria semiótica do texto de A. J. Greimas e os estudos de semiótica visual e semissimbolismo de Jean-Marie Floch.

Building Stories (2012), o corpus principal desta pesquisa, é uma das obras mais recentes do quadrinista norte-americano Chris Ware. Publicada pela editora Pantheon ${ }^{1}$, esse trabalho é sui generis, sendo composto não por um livro, mas por um conjunto de quatorze impressos que variam de formato entre si (sem numeração de páginas ou títulos, há álbuns, livros de capa dura, um tabuleiro, tiras de papel, impressões que se assemelham em formato e tamanho a cadernos de jornal, etc.). Por meio da distribuição não ordenada dos impressos que compõem a caixa, o leitor tem a possibilidade de dispor da ordem que quiser para ler as histórias, construindo novas formas de apreciá-las.

A história de Building Stories acompanha os moradores de um edifício em Chicago, tendo como protagonista uma jovem que não possui uma perna, a qual é acompanhada antes, durante e depois de sua residência no prédio. Ware lida com temas comuns às suas obras, como a melancolia, a solidão, a rotina e as relações humanas. Por meio da experimentação formal, o autor extrapola a experiência de leitura dos quadrinhos, oferecendo histórias que, além da apresentação de narrativas, oferecem na sua composição plástica a criação de novas camadas de sentido.

\footnotetext{
${ }^{1}$ Há histórias dentro de Building Stories já publicadas anteriormente: seja na revista de Ware, The Acme Novelty Library, ou no periódico The New Yorker. Estudar as publicações prévias não se faz necessário neste trabalho, ficando o objeto de estudo restrito à publicação de 2012.
} 
Sendo estas narrativas gráficas, considera-se necessário analisar os mecanismos sintáxicos e semânticos responsáveis pela produção do sentido. Logo opta-se, como ponto de partida para a análise, a aplicação da teoria semiótica do texto, proposta por Algirdas Julien Greimas, de forma que se verifique o desenvolvimento narrativo nas histórias de Ware, assim como os efeitos de sentido produzidos. Como Greimas e Courtés (2013, p. 362) descrevem, o termo percurso "implica não somente uma disposição linear e ordenada dos elementos entre os quais se efetua, mas também uma progressão de um ponto a outro, graças a instâncias intermediárias". A análise pelo percurso gerativo do sentido, observando seus níveis (fundamental, narrativo e discursivo) visa, nesta pesquisa, a tornar mais abrangente a interpretação das narrativas gráficas de Ware.

Enquanto texto que apresenta duas linguagens (verbal e visual), se faz necessário também analisar os quadrinhos a partir do plano de expressão. Jean-Marie Floch, trata, em Petites mythologies de l'œil et de l'esprit (1985, p. 13-14), daquilo que chama de semiótica plástica, apresentando como proposta a compreensão das relações entre o significante visual e o significado, através da lexicalização da dimensão figurativa dentro dos formatos, cores e posições dos elementos plásticos. A relação estabelecida entre plano de expressão e de conteúdo é denominada relação semissimbólica. Em suas análises, Floch aplica o semissimbolismo em diversas produções, entre elas, os quadrinhos. Percebem-se, nessas relações, oposições de valores e texturas e o seu papel na criação de efeitos de sentido. Floch propõe, então, categorias plásticas, que são: (i) eidéticas, relacionadas às formas (ex.: arredondado vs. retilíneo); (ii) cromáticas, relacionadas às cores (ex.: claro vs. escuro) e (iii) topológicas, relacionadas às posições (ex.: englobante vs. englobado).

Neste trabalho, o objetivo da análise é mostrar como os elementos plásticos constroem o sentido, aliados ao plano de conteúdo. Paralelamente, nas análises das duas histórias será observado como a estruturação diagramática dos textos oferece outros níveis de leitura e criam seus efeitos de sentido.

O primeiro capítulo, "O quadrinho experimental - do underground a Chris Ware" visa não apenas apresentar o autor, mas contextualizá-lo em relação ao movimento que o antecedeu e àquele ao qual pertence, o underground e o alternativo, respectivamente. Conforme é observado por Jakobson (2015, p. 154), “toda época contemporânea é vivida na sua dinâmica temporal e, por outro lado, a abordagem histórica, na poética como na linguística, não se ocupa apenas de mudanças, mas também de fatores contínuos, duradouros, estáticos". O underground foi um movimento de ruptura com o quadrinho mainstream (o qual tem como grandes nomes 
as editoras Marvel e DC Comics) e uma resposta às limitações sofridas pelos quadrinistas, tanto pela censura quanto pelas práticas editoriais de seu tempo. Apesar de sua breve existência, o underground transformou radicalmente o cenário dos quadrinhos, colocando em destaque a figura do autor. Era incentivado o experimentalismo narrativo e gráfico, o quadrinista dispunha de total autonomia e destruía-se a noção de quadrinhos como produto apenas voltado ao público infantil (seus conteúdos eram politicamente engajados, irreverentes e não raro obscenos). Após o fim do movimento, surgiram diversas vertentes. Uma delas, o alternativo, tinha outras ambições, como uma busca pela legitimação do quadrinho enquanto arte, por meio de um experimentalismo formal mais sofisticado e a exploração de temas densos.

O capítulo também apresenta Chris Ware em maiores detalhes. Uma breve biografia cobre o percurso do autor nos quadrinhos, suas influências, estabelecendo relações com o movimento do qual faz parte e aquele que o antecedeu. $\mathrm{O}$ caráter experimental do trabalho de Ware é explorado, com destaque para elementos característicos das criações do autor, como (i) a construção diagramática; (ii) as diferentes formas de trabalhar com o texto, com a possibilidade de criar a identificação ou diferenciação entre os elementos verbais e plásticos; e (iii) a abordagem de temas comuns a outros autores alternativos, como as relações humanas e a solidão.

No segundo capítulo, “A leitura alternativa - análise de histórias individuais”, analisamse duas histórias, escolhidas por apresentarem características que permitem compreender a proposta de Building Stories. A primeira, composta de apenas uma tira de papel, apresenta a possibilidade de uma leitura circular: não há definição de onde a história começa ou termina. A segunda envolve, na verdade, duas histórias, as quais se relacionam tematicamente e plasticamente, além de oferecerem a possibilidade de diferentes escolhas de leitura (começando por uma ou pela outra). A escolha oferece diferentes perspectivas sobre as personagens, embora se preserve a compreensão geral do texto. Aplica-se o método de análise do texto proposto por Algirdas Julien Greimas, observando o percurso gerativo do sentido e o desenvolvimento narrativo das histórias selecionadas. Paralelamente, a análise considera as construções semânticas do texto no plano de conteúdo, as de ordem plástica no plano da expressão e a realização de sua relação semissimbólica, conforme proposto por Jean-Marie Floch.

Um terceiro item neste capítulo também busca apresentar, brevemente, considerações sobre a construção do tempo na obra de Ware. Aplica-se a teoria proposta por Zilberberg (2006) sobre o fazer missivo: mais especificamente, as noções de cronopoiese e cronotrofia, abertura e fechamento do espaço (idem, p. 137). É explorada a sua problemática na representação de 
tempo e espaço, além das estratégias gráfico-narrativas utilizadas por Ware para adotar e subverter as convenções da linguagem dos quadrinhos, criando diferentes efeitos de sentido.

O último capítulo, aborda Building Stories sob a ótica da sua proposta de leitura e a fragmentação da narrativa. Observa-se a interdiscursividade da obra com outras, da arte e dos quadrinhos. A fragmentação da narrativa é analisada sob o viés semiótico, considerando aproximações entre a proposta do quadrinho e as noções de paradigma e sintagma de Saussure, verificando o efeito de sentido criado pelo ato de leitura, à maneira do labirinto.

O presente trabalho concentra a pesquisa sobre uma obra que é não apenas recente (com publicação em 2012), como também grande, tanto em dimensões quanto em complexidade. O que se propõe, portanto, não é uma leitura definitiva da obra e da prática de Ware, mas sim a demonstração da engenhosidade do autor e de Building Stories, porquanto limitado seja o recorte feito para a análise. Aplica-se o olhar semiótico para observar a narratividade das histórias e os traços que permitem identificá-lo como quadrinho experimental, buscando acrescentar mais uma voz à discussão, dentro da academia, sobre essa produção contemporânea.

Os anexos presentes nesta dissertação oferecem as duas histórias analisadas no segundo capítulo para leitura, acompanhadas de tradução nossa, visto que Building Stories ainda não apresenta uma edição traduzida para o português. Tal consideração é dada visto que esta pesquisa é financiada pelo governo brasileiro, foi desenvolvida em uma faculdade no País e, portanto, se faz necessário estabelecer o diálogo com os leitores, pesquisadores e estudantes brasileiros. É importante lembrar, no entanto, de duas coisas: (i) que as traduções buscam apenas tornar o texto inteligível para os falantes de português, não podendo ser consideradas equivalentes a uma tradução oficial do quadrinho; e (ii) devido ao tamanho físico considerável de cada história, seria impossível incluí-las integralmente na página, então os quadros apresentam-se desmembrados com as respectivas traduções de cada trecho abaixo dos mesmos. 
1. O QUADRINHO EXPERIMENTAL - DO UNDERGROUND A CHRIS WARE 


\subsection{A herança do quadrinho experimental - um recorte diacrônico}

As histórias em quadrinhos são um produto cultural com longa história. De Rodolphe Töpffer aos autores contemporâneos, há enorme variedade nesta produção, dentro e fora do que é chamado de mainstream. Desde seus primórdios, os quadrinhos passaram por diversas transformações, tanto formais quanto temáticas, sendo seus elementos formais e narrativos objeto de estudo teórico dentro e fora da semiótica. Aplica-se aqui a noção de quadrinhos enquanto sistema que comporta as linguagens verbal e visual, ao mesmo tempo que possui suas próprias convenções, considerando-os "como um conjunto original de mecanismos produtores de sentido" (GROENSTEEN, 2015, p. 10). Visando explorar a evolução dessa linguagem, particularmente naquilo que se refere a movimentos que privilegiaram a produção experimental e autoral, coloca-se como necessário fazer um recorte diacrônico do quadrinho, com foco na produção norte-americana.

Antes de começar a exploração do quadrinho de Chris Ware, portanto, sua obra será contextualizada diacronicamente: mais especificamente, com a apresentação do movimento que deu origem a toda uma geração de quadrinistas que produziram trabalhos cada vez mais inovadores e autorais. Para isso, este capítulo observa brevemente o contexto dos quadrinhos na década de 1960 e 1970, o surgimento dos underground comix, seu impacto no meio e sua divisão em várias vertentes, com destaque ao quadrinho alternativo. A consideração desse, por sua vez, permite verificar suas características e oferece uma introdução para a última parte deste capítulo, que envolve conhecer melhor Chris Ware, seu percurso como quadrinista e o caráter experimental de seu trabalho.

\subsubsection{A ruptura dos underground comix}

Década de 1960: o mercado norte-americano de quadrinhos tinha Marvel e DC Comics como duas das grandes (senão as maiores) editoras norte-americanas. Suas publicações eram vendidas ao público nas bancas de jornal e, por conta disso, eram submetidas ao CCA (Comics Code Authority): um código implementado em 1954 pelas próprias editoras, regulava sobre a presença de horror, violência, depravação, crime e obscenidade ${ }^{2}$. A censura do CCA limitava

\footnotetext{
${ }^{2} \mathrm{O}$ contexto que levou ao CCA teve como momento marcante a publicação de $A$ Sedução do Inocente (1954), do psiquiatra alemão Fredric Wertham, mas não se deve somente a isso. Conforme Reblin (2015,
} 
consideravelmente a liberdade das editoras, assim como reforçava a ideia de quadrinhos como produto que visava apenas ao público infantil. Como forma de resistência (ao CCA, às políticas editoriais e às fórmulas do quadrinho tradicional), jovens começaram a criar suas próprias histórias: produzidas de forma independente e publicadas não por grandes editoras, mas sim por revistas de humor e jornais de contracultura (DUNCAN, SMITH, 2009, p. 52). Esses quadrinhos não-convencionais receberam o nome de underground comix.

O underground tem por característica a criação autoral. Dentro das grandes editoras, o processo de produção e publicação em massa é análogo ao das linhas de produção industrial, com profissionais responsáveis, respectivamente, pelos traços, cores, arte-final, roteiro e lettering. Os quadrinistas underground, por sua vez, não dispunham de uma equipe para produzir suas histórias, ficando sob responsabilidade do mesmo autor cuidar de todas as etapas do processo criativo. A publicação das histórias, por sua vez, ficava ou a cargo do próprio quadrinista, ou integrava fanzines de contracultura que eram vendidos nas chamadas head shops (lojas que vendiam parafernália para o consumo de drogas). As origens do movimento são incertas, sendo relacionadas a diversas fontes: os zines amadores, os jornais underground e os jornais de humor acadêmicos. Dentre as influências do movimento, destacam-se (i) os Tijuana Bibles $^{3}$, (ii) a revista humorística Mad (que começou como quadrinho satírico, sob a edição de Harvey Kurtzman, e sobreviveu à censura do CCA ao se tornar uma revista), (iii) os quadrinhos de horror dos anos 1950 (cujas representações de sensualidade e violência gráfica tornaram essas publicações o alvo do CCA), (iv) animações e quadrinhos antigos e (v) tiras de jornal.

p. 45-50) coloca, o período pós-Segunda Guerra foi marcado não apenas por um aumento da delinquência juvenil, como também a histeria anticomunista no mundo ocidental e, especialmente, nos Estados Unidos, que influenciou a população e a Indústria do Entretenimento. Isso levou a uma "caça às bruxas" contra tudo que era considerado contrário aos "verdadeiros valores americanos" e os quadrinhos, por sua vez, eram considerados prejudiciais às crianças e jovens, especialmente os quadrinhos de crime e horror. As críticas iam desde à preocupação com o desenvolvimento mental dos jovens, até a acusação de que os quadrinhos estimulavam as crianças a agir violentamente. A publicação do livro de Wertham, por sua vez, legitimou a crítica aos quadrinhos como instrumentos da degradação social. A reação foi tamanha que levou a uma investigação no Congresso dos Estados Unidos sobre o conteúdo dos quadrinhos. Temendo uma intervenção direta do governo estadounidense e buscando recuperar o mercado editorial, as editoras fundaram a associação Comics Magazine Association of America e criaram, então, o CCA.

${ }^{3}$ Pequenos quadrinhos de oito páginas que eram ilegais não apenas por violarem leis de copyright (não raro as histórias apresentavam personagens fictícios como Mickey Mouse, personalidades da política e celebridades), mas também por colocarem seus personagens em situações sexuais e obscenas. 
É difícil estabelecer de maneira precisa qual foi o primeiro quadrinho underground, devido à maneira peculiar como as histórias eram produzidas e distribuídas. O quadrinho underground no formato de revista convencional ${ }^{4}$ (ou semelhante a ela) data do final da década de 1960. O exemplo mais notório é, sem dúvida, Zap Comix \#1 (1968, Figura 1), de Robert Crumb. Conforme é colocado por Charles Hatfield (2005, p. 28, tradução nossa),

Crumb demonstrou que era possível (apesar de não ser fácil) para um cartunista tomar totalmente o controle de uma embalagem cujas dimensões estavam designadas para a produção com caráter de linha de montagem. Crumb usurpou o que era, até então, o veículo mais comum para quadrinhos extensos, o quadrinho de banca, e transformou em um receptáculo de aparência amigável para histórias que dificilmente seriam colocadas em bancas de jornal, devido aos seus conteúdos iconoclastas, por vezes escabrosos e, de fato, radicais.

Zap trouxe uma nova visão sobre quadrinhos, enquanto usufruía de uma liberdade comercial muito particular, o que ampliava o leque de possibilidades artísticas e expressivas de seus criadores. O quadrinho se tornou um fenômeno e Crumb, uma celebridade. Graças à sua fama, o autor alimentou o crescimento dos quadrinhos underground para além do seu nicho e público alvo.

\footnotetext{
${ }^{4}$ As referências anglófonas de quadrinhos utilizadas para esta pesquisa trazem o termo comic book. Para evitar ambiguidades, o termo "revista em quadrinhos convencional" refere-se ao comic book e seu formato. Trata-se do formato padronizado para o mercado norte-americano (e que engloba não publicações quaisquer que contenham quadrinhos, mas aquelas voltadas apenas para eles): periódicos, com folhas grampeadas, papel de baixo custo e capas de papel brilhante. Esse formato é descendente das revistas pulp, voltado para a venda em bancas de jornal (HATFIELD, 2005, p. 8).
} 
Figura 1 - capa da Zap Comix \#1 (1968).

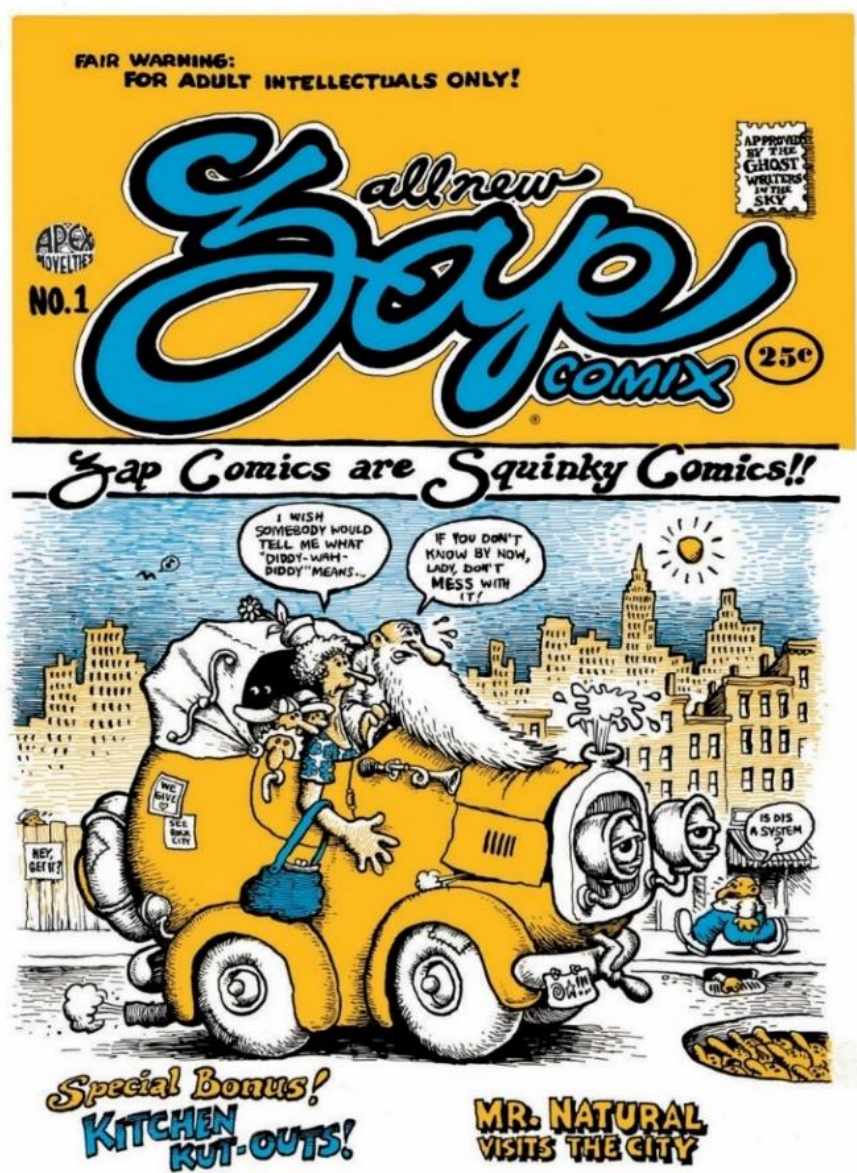

Fonte: CRUMB (2014)

Os comix provocaram uma mudança radical: a noção de quadrinhos voltados para o público adulto (é possível ver na capa da Zap a observação irônica: “apenas para adultos intelectuais"). O público adulto já tinha acesso a quadrinhos nas tiras de jornal, mas foram os underground comix que transformaram esse produto cultural em algo voltado para um grupo específico. Isso significa que havia surgido uma plataforma para meios de expressão mais pessoais e a criação de objetos mais experimentais, de natureza autoral. A apropriação da revista em quadrinhos, um produto com características comerciais (e sujeito às limitações do seu mercado), trouxe a subversão do veículo. A tensão entre o caráter mercadológico do quadrinho convencional e o perfil libertário da produção do underground fez surgir um novo objeto e diversas possibilidades de expressão.

A busca pela quebra da identidade do quadrinho como produto infantil trouxe um caráter desafiador aos underground comix. Sexo, drogas, violência extrema (e gráfica), irreverência no humor e posições políticas radicais fizeram parte da estética e temática do movimento. 
Elementos comuns da revista em quadrinhos comercial eram colocados em evidência e parodiados: o selo de aprovação do CCA, páginas com publicidade, logotipos. A zombaria com os aspectos comerciais e editoriais do quadrinho fazia crítica ao consumismo norte-americano, assim como às práticas das grandes editoras, limitadas pela censura auto-imposta do período e às pressões do mercado. A ironia se estendia também na apropriação e subversão de personagens, estilos e gêneros (é possível identificar nos trabalhos de Crumb, por exemplo, a referência aos desenhos e animações da primeira metade do século XX). Muitos quadrinistas utilizavam ideias e estilos herdados dos quadrinhos mais antigos, como animais antropomorfizados, super-heróis e os quadrinhos de horror dos anos 1950 publicados pela editora EC Comics. O traço de muitos quadrinistas era intencionalmente irregular, deixando mais evidente a expressão do autor. A característica pessoal desses quadrinhos e sua produção cada vez maior mostrou a diversidade de estilos e narrativas possíveis.

É interessante ressaltar que houve no meio uma vertente de quadrinistas que apresentavam outras sensibilidades, objetivos e inspirações. Autoras como Trina Robbins criaram quadrinhos de viés feminista, com histórias satíricas envolvendo heroínas e uma estética que fazia referência ao glamour dos anos 1940. Trina se juntou a outras quadrinistas e criou a editora coletiva Wimmen's Comix Collective. Outras autoras criaram suas próprias antologias, uma resposta ao ambiente masculino fechado do underground (ironicamente, apesar das críticas feitas pelos seus autores à realidade do mercado editorial da época, a pequena presença de mulheres no meio era muito semelhante àquela das mulheres no mainstream). Fantasias pornográficas dos autores apresentavam, pelo olhar dessas mulheres, uma inversão dos papéis sexuais e uma representação mais aberta e crua do corpo feminino (MAZUR, DANNER, 2014, p. 30-31).

Em meados dos anos 1970, o underground sofreu um revés. A Suprema Corte norteamericana, em 1973 (caso Miller vs. Califórnia), decidiu que conteúdos obscenos não estavam protegidos pela Primeira Emenda e comunidades locais teriam o poder de determinar seus padrões de obscenidade. A corte também estabeleceu um teste para esses conteúdos, algo que nenhum quadrinho underground teria a possibilidade de passar. Estados também buscavam estabelecer leis para tornar ilegal a venda de qualquer item ligado à produção e consumo de drogas, o que afetou os negócios das head shops, onde eram vendidos muitos desses quadrinhos $^{5}$. Simultaneamente, o cenário cultural havia também mudado: a postura

\footnotetext{
${ }^{5}$ Durante o período, surgia aos poucos um novo sistema de distribuição de quadrinhos, o chamado "mercado direto", caracterizado pelas lojas especializadas em quadrinhos. Voltado principalmente aos
} 
contestadora perdia sua força; seus leitores, antes universitários, não compunham mais o perfil ao qual o underground atendia; os coletivos, que trabalhavam para publicar de forma barata os quadrinhos, tiveram seus membros transformados em editores; seus temas viraram clichês sem força política e o mainstream aos poucos buscou cooptar o movimento.

Apesar de alguns autores estabelecidos, como Crumb, ainda publicarem por conta própria, o underground mostrava-se esgotado. Os quadrinhos passaram, então, por um processo de transformação, iniciado na segunda metade da década de 1970, desenvolvido a partir do legado do underground. Essas novas vertentes apresentavam, à sua maneira, proximidades e distâncias do movimento que as antecedeu:

(i) Ground level: o termo descreve quadrinhos que exploravam os gêneros próximos ao mainstream, mas preservando as sensibilidades do underground. Os artistas conservavam os direitos autorais dos seus personagens e, editorialmente, eram menos restritos, enquanto as histórias envolviam aventuras de fantasia e ficção científica. O ground level foi uma fase breve, na qual criadores mais próximos do quadrinho tradicional buscavam aproximação com as publicações alternativas iniciadas pelo underground. Os quadrinhos não estavam sujeitos à censura do CCA, apresentando violência, sexo e nudez. Seus criadores, por sua vez, tinham ali a possibilidade de manter uma certa distância artística e criativa do mainstream e suas práticas, mas também abriam as oportunidades de trabalhar nesse mercado.

(ii) Newave: termo referente ao fenômeno iniciado da metade dos anos 1970 até os anos 1980. Seus quadrinhos eram pequenos e de impressão barata, sendo chamados também de minicomix. As características de impressão, produção e distribuição informais o aproximavam do underground, além do caráter confessional e anárquico de suas histórias. Isso é evidente no New Wave Manifesto, do jornalista e editor Clay Geerdes, que dizia "a Newave é o que Mad teria sido se a equipe não tivesse optado pela distribuição em massa e a censura que isso implica. A Newave reúne tudo o que a $M A D$, a Cracked e a Crazy têm

colecionadores, ele atendia o público consumidor do mainstream, mas também acolheu os undergrounds. Isso permitiu que os autores ainda tivessem alguma forma de levar seus trabalhos ao público, ainda que em um número menor do que conseguiam antes nas head shops. 
de deixar de fora" ". Apesar do caráter artesanal e muitos de seus criadores serem "órfãos" do colapso do movimento underground, alguns autores renomados do movimento anterior produziram para o gênero, como Trina Robbins e Art Spiegelman.

(iii) Independente: termo aplicado às novas editoras que buscavam competir com os grandes nomes do mainstream (com destaque para DC e Marvel). A produção do independente criava histórias de ficção voltadas para o público do mainstream, muitas vezes cobrindo muitos gêneros diferentes, desde traduções de mangás japoneses até quadrinhos documentais, com abordagem jornalística. As práticas dos independentes acabaram por impactar a indústria tradicional de quadrinhos: os criadores recebiam royalties e eram donos da propriedade intelectual de suas criações. Com o tempo, isso fez com que DC e Marvel tivessem que conceder um pouco e negociar contratos mais atraentes para seus artistas. A ampla exploração criativa dos independentes também impactou a grande indústria dos quadrinhos, ao abrir portas para seus criadores irem às grandes editoras e apresentar novas formas de contar histórias, dentro ou fora do mainstream.

\subsubsection{Os quadrinhos alternativos}

A era pós-underground fez com que quadrinistas buscassem novas alternativas ao quadrinho autoral, com materiais mais autobiográficos, como foi o caso de Art Spiegelman, quando começou a produzir as histórias de Maus (com uma de suas partes publicada originalmente na revista Funny Aminals, em 1972); ou com Harvey Pekar, em American Splendor (1976, feito em parceria com Robert Crumb). A busca por quebrar tabus, típica do underground, não era mais uma preocupação, também. Os quadrinhos apresentavam outra sensibilidade, em que as histórias se apresentavam mais pessoais e complexas, sem a intenção de apenas chocar o leitor. Atribui-se à revista Arcade: the Comics Revue (1975), concebida por

\footnotetext{
${ }^{6}$ GEERDES, 1983 (apud). In: MAZUR, Dan, DANNER, Alexander. Quadrinhos: História moderna de uma arte global. Tradução: Marilena Moraes. São Paulo: Editora WMF Martins Fontes, 2014, p. 194.
} 
Art Spiegelman e Bill Griffith, o papel de produção transicional do underground para o alternativo (DUNCAN, SMITH, 2009, p. 67).

Durante os anos 1980, quadrinho alternativo era o nome dado ao objeto criado por um único quadrinista, apresentando um viés mais autoral e pessoal. Os alternativos apresentavam uma preocupação maior com o olhar de seus autores, traços autobiográficos e experimentação formal. Os quadrinhos não estavam alinhados ao perfil cáustico do newave, com seu caráter mais democrático e visceral: as histórias queriam-se mais experimentais do ponto de vista narrativo e gráfico, com a busca por respeitabilidade e da visão de quadrinhos como arte. Os alternativos buscaram extrapolar os limites estéticos e culturais dos quadrinhos, revitalizandoos e redefinindo-os (HATFIELD, 2005, p. 31).

Figura 2 - Capa da revista $R A W$ Vol. 2, publicada em julho de 1989

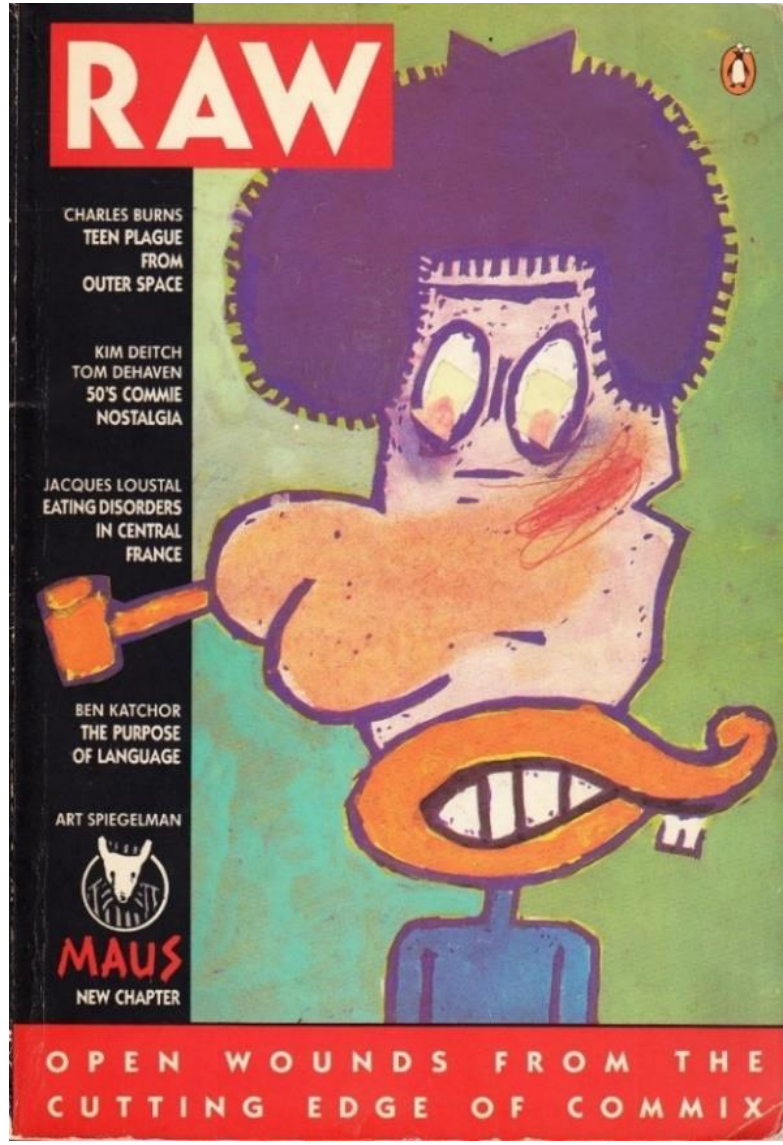

Fonte: SPIEGELMAN; MOULY (1989).

Em 1981, Art Spiegelman lançou, com Françoise Mouly, a antologia $R A W$, na qual Maus foi serializada. A preocupação estética estava presente nas grandes dimensões da revista, de forma que se evidenciassem o experimentalismo e as qualidades plásticas das histórias. 
Vários quadrinistas célebres tiveram seus primeiros trabalhos publicados na antologia, como Dan Clowes, Richard McGuire e Chris Ware.

Figura 3 - Primeira página de Here (1989), de Richard McGuire, publicada na antologia $R A W$.
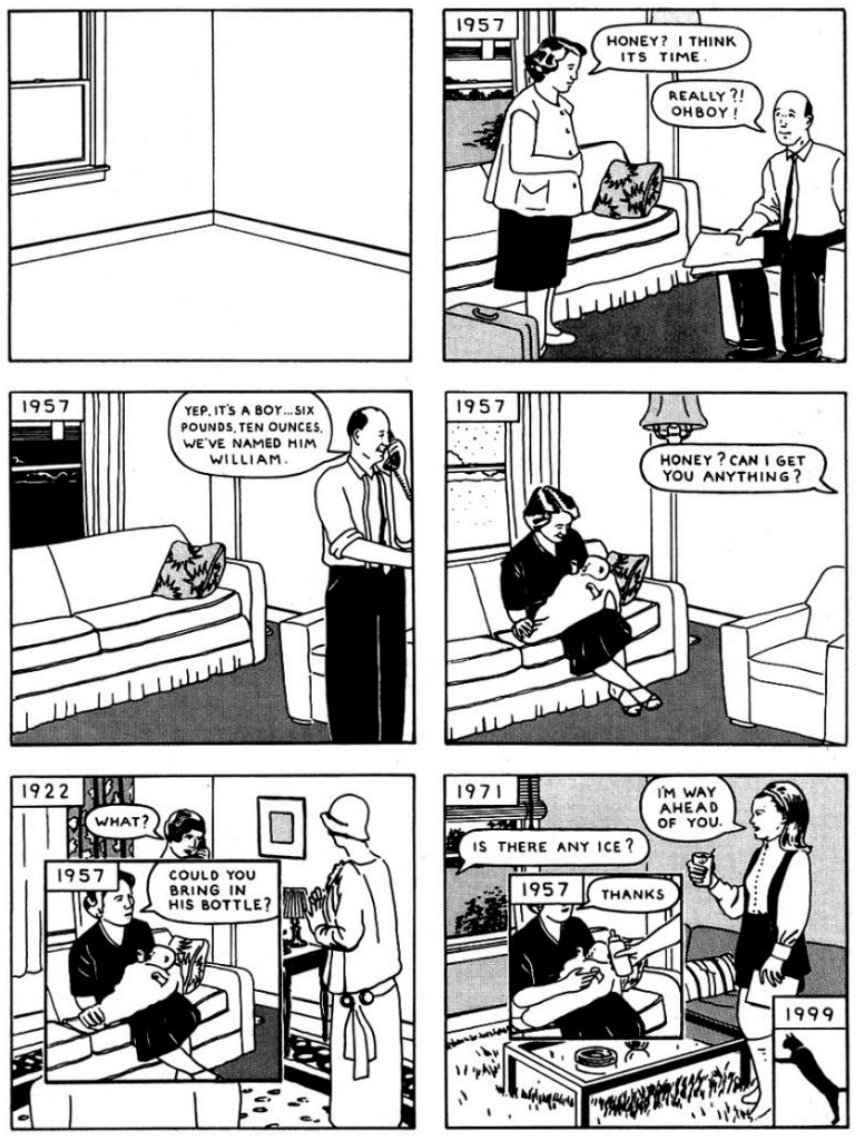

Fonte: McGUIRE (1989)

Durante o mesmo período, ganhava força dentro e fora do mainstream o formato graphic novel, que trazia nova visão sobre os quadrinhos. As graphic novels proporcionaram liberdade narrativa e estética aos seus criadores, assim como uma maior diversidade nos quadrinhos. Will Eisner (2013, p. 7) coloca: "esta última transformação impôs uma necessidade de sofisticação literária por parte do escritor e do artista maior do que nunca”. O surgimento da graphic novel promoveu também a transformação na realidade editorial, permitindo o experimentalismo com o formato e as abordagens gráficas da narrativa.

Enquanto os underground comix se diziam "apenas para adultos" por abordarem de maneira explícita sexo, nudez, drogas e violência, os alternativos marcaram seu distanciamento com o público infantil pela abordagem de temas densos e complexos. Isso é evidente em Maus (1986), uma história sobre o holocausto, em que as diferenças de nacionalidade e raça eram 
marcadas na representação dos diferentes grupos como animais (judeus como ratos, nazistas como gatos, etc.). Em 1992, Maus ganhou o Pulitzer, feito este que marcou uma fase importante para os quadrinhos e sua legitimação como objeto de estudo e crítica.

Figura 4 - quadros de Maus (1986), de Art Spiegelman

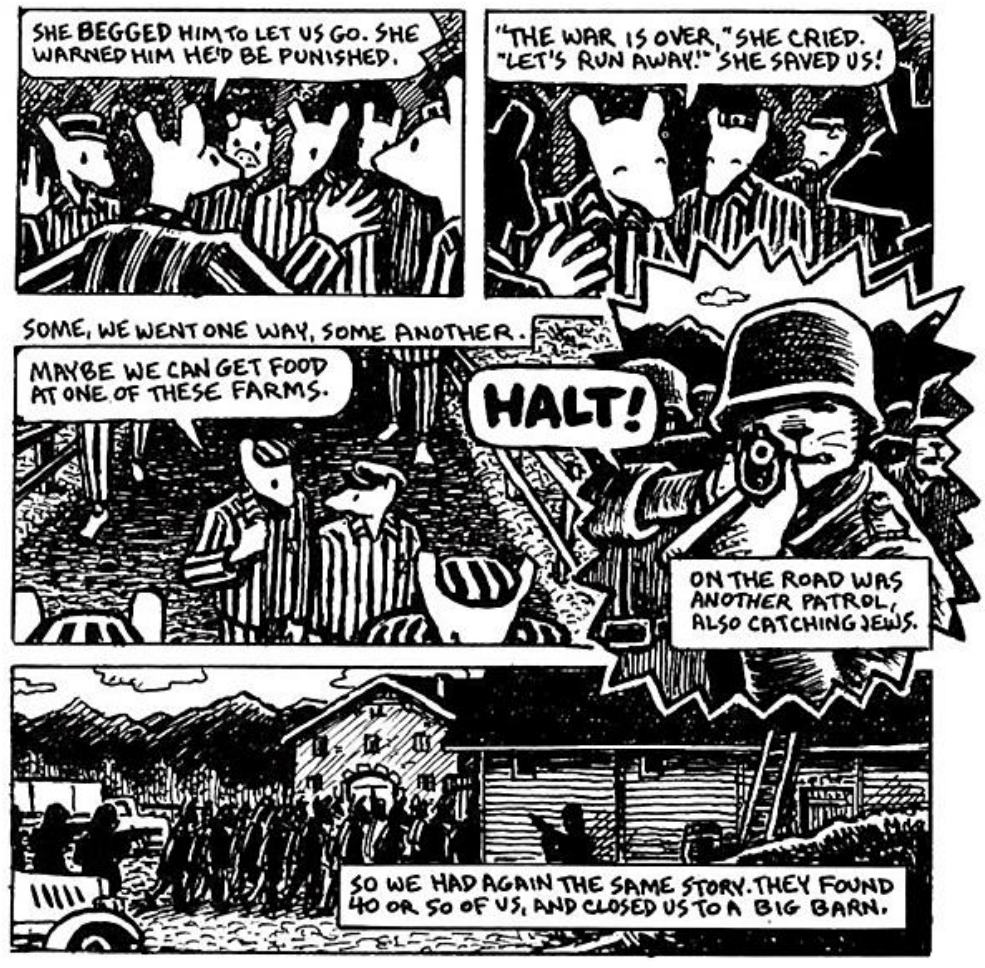

Fonte: SPIEGELMAN (2003)

Os anos 1990 foram marcados pela maior presença dos quadrinhos alternativos no já consolidado mercado direto. Havia inclinação para o realismo, a nostalgia e a melancolia: muitos personagens eram alienados da sociedade, angustiados e tristes. Mazur e Danner (2014, p. 238-239) atribuem isso à frustração dos autores com o meio, ainda sem o prestígio cultural esperado nos Estados Unidos (e considerado ainda algo infantil), assim como à "herança" das tiras Peanuts, de Charles Schulz, e seu protagonista melancólico, Charlie Brown.

Outras produções do quadrinho alternativo apresentavam diferentes perfis. De produções autobiográficas com cunho político, como Persépolis (2000), de Marjane Satrapi, às histórias que perpassam décadas de Love and Rockets (iniciada em 1982 e ainda em produção), dos irmãos Hernandez, ou até mesmo os quadrinhos jornalísticos de Joe Sacco, como Goražde (2000), é possível perceber que há grande variedade estilística e temática, o que torna a classificação "alternativo" uma maneira de englobar essas diferentes produções autorais como parte de longa fase (ainda em curso) na produção de quadrinhos. 


\subsection{Conhecendo Chris Ware}

Nascido em 28 de dezembro de 1967, em Omaha, Nebraska (Estados Unidos da América), Chris Ware é o homônimo de Franklin Christenson Ware. O quadrinista começou seus estudos de arte na University of Texas, trabalhando como cartunista para o jornal da faculdade. Suas primeiras tiras, publicadas entre 1987 e 1991, já indicavam o interesse em jogar com as convenções formais dos quadrinhos. Em 1991, Ware matriculou-se no Art Institute de Chicago. Esse foi um momento de transição importante em sua carreira: apesar de ter se desiludido com a academia, o repertório artístico adquirido influenciou o seu trabalho (e vale dizer, a própria experiência de Ware no ambiente acadêmico se coloca como influência, algo expressado por seus personagens) (KUHLMAN, BALL, 2010, p. 13-14).

Em 1990, Ware foi convidado por Art Spiegelman para produzir uma história de quatro páginas para a antologia $R A W$. Ware publicou dois trabalhos para $R A W$ : Waking up blind (publicada no segundo número do volume 2, em 1990) e I Guess (também conhecida como Thrilling Adventure Stories, publicada no terceiro número do volume 2, em 1991).

Em 1993, publicou pela Fantagraphics o quadrinho serializado ACME Novelty Library. Não há previsão de conclusão da série, sendo seu mais recente volume publicado em 2010 (e distribuído pela editora Drawn \& Quarterly). A série é marcada pela aparição de personagens icônicos de Ware, como Quimby e Jimmy Corrigan (este, depois protagonista da graphic novel Jimmy Corrigan: o menino mais esperto do mundo, publicada originalmente em 2000 pela editora Pantheon e, no Brasil, pela Companhia das Letras em 2009), assim como a aparição de histórias pertencentes a Building Stories no volume 16 e 18 da ACME Novelty Library, publicada em 2007.

Ware já era, no começo dos anos 2000, um quadrinista de reputação estabelecida, mas Jimmy Corrigan colocou o trabalho do autor em evidência, após receber os prêmios literários American Book Award (2001) e o Guardian First Book Award (2001) ${ }^{7}$. O prestígio dessas premiações trouxe nova atenção ao autor, especialmente para aqueles não familiarizados com a produção contemporânea de quadrinhos (e, particularmente, o quadrinho alternativo). Desde então, Ware publicou em 2003 seu segundo livro, Quimby the Mouse (2003), Building Stories

\footnotetext{
${ }^{7}$ Desde os anos 1990, Chris Ware já ganhou mais de 20 prêmios por seu trabalho como colorista, letrista e quadrinista, entre eles o Harvey Award, Eisner Award e o Angôuleme Grand Prix, citando alguns.
} 
(2012) e, mais recentemente, Monograph by Chris Ware (2017): este, um trabalho autobiográfico, que mistura relatos e fotos pessoais, imagens de experimentações gráficas do seu começo de carreira e reproduções de obras originais.

O autor produziu também quadrinhos e ilustrações para revistas como New York Times Magazine e The New Yorker. Sobre esta última, é interessante observar o interesse de Ware no experimentalismo além dos quadrinhos, algo que o próprio autor descreve como "os editores me permitem testar a paciência dos leitores da revista com experimentos em prolongamento narrativo: múltiplas capas simultâneas, capas dobráveis e quadrinhos conectados dentro da edição" " Exemplo disso é a capa da edição publicada em 2015, intitulada Mirror. A capa é acompanhada por uma animação (baseada no áudio de uma mãe relatando um episódio em que fez um comentário inadequado sobre a aparência de sua filha) desenvolvida por Ware e John Kuramoto. A animação, também um "prolongamento narrativo", expande a narrativa apresentada pela capa de revista convencional, apresentando um objeto híbrido de quadrinhos e vídeo.

A ACME Novelty Library apresenta referências de estilo do design gráfico do começo do século XX (como anúncios publicitários e quadrinhos do período). O autor emula os estilos de outrora, que formaram seu repertório cultural, incorporando-os à sua criação. Apesar do cuidado estético e inspiração nas produções antigas, as histórias de Ware mostram personagens dentro de um mundo moderno e estéril (MAZUR, DANNER, 2014, p. 238). A melancolia de seus personagens é contrastada pelas referências gráficas, criando novas camadas de leitura para as histórias.

Nos quadrinhos, as tiras Peanuts (1950-2000) de Charles Schulz, influenciaram não apenas Ware como outros quadrinistas alternativos, conforme foi dito anteriormente. As tiras de Schulz fizeram parte da infância de muitos quadrinistas dos anos 1990 e 2000, incluindo Ware, sendo o melancólico protagonista Charlie Brown referência para esses autores. Semelhante aos quadrinistas underground, que encontraram inspiração nos seus antecessores do começo do século XX, Chris Ware apresenta como outras referências os quadrinhos de Frank King (Gasoline Alley), Winsor McCay (Little Nemo in Slumberland), George Herriman (Krazy

8 WARE, Chris. Cover story: moving images. The New Yorker. Disponível em: <https://www.newyorker.com/culture/culture-desk/cover-story-2015-12-07>. Acesso em 10 de novembro de 2017. 
Kat) e também os quadrinhos de super-heróis dos anos 1930 e 1940 (período conhecido como a Era de Ouro dos quadrinhos).

A influência de quadrinistas clássicos, tais como King e McCay, é perceptível nas escolhas estéticas de Ware. A Figura 5 apresenta Crazy Quilt (1914), uma criação colaborativa de King e outros, descrita por Thierry Smolderen (2014, p. 87) como interesse de King e outros quadrinistas em explorar as possibilidades da página, contrastando a totalidade do espaço gráfico-narrativo (e o ponto de vista do leitor, que tem a visão geral da história), com o acompanhamento da narrativa emaranhada. Histórias como essa permitem notar a presença do experimentalismo nos quadrinhos muito antes do movimento dos underground comix, embora isso se dê em razão de não existir, à época desses quadrinistas, uma linguagem dos quadrinhos consolidada como a conhecemos hoje. Enquanto nova forma de comunicação e produto cultural, portanto, estavam à disposição dos autores diversos caminhos possíveis.

Figura 5 - Crazy Quilt, parte 4, de Frank King et al., publicada no jornal Chicago Tribune em 3 de maio, 1914.

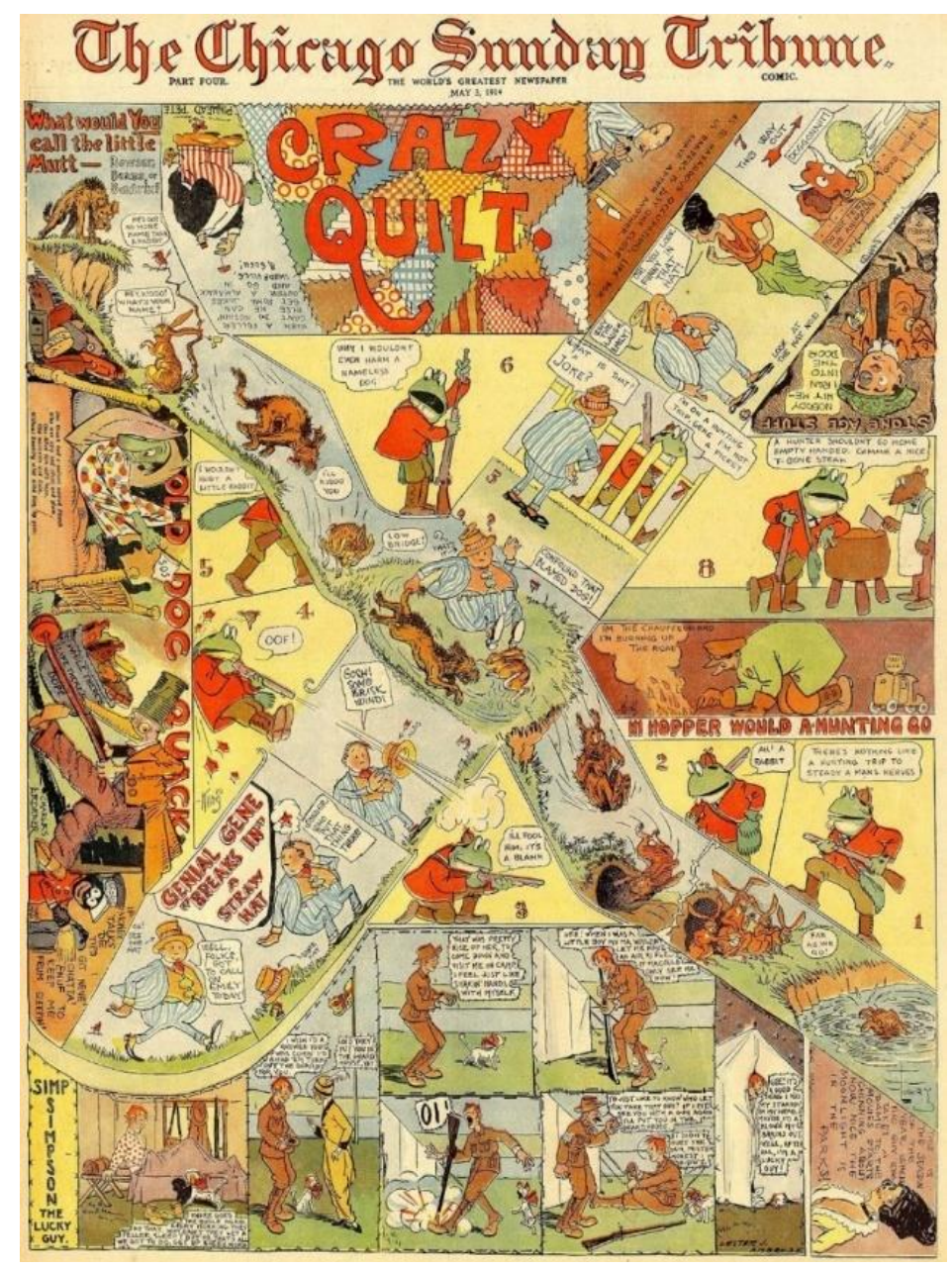

Fonte: SMOLDEREN (2014) 
A Figura 7, por sua vez, é outro exemplo de como Ware incorpora suas referências na construção da narrativa. Ao desenhar a história no estilo dos quadrinhos da Era de Ouro (Figura 6), o autor cria um pastiche ${ }^{9}$ dos quadrinhos de outrora.

Figura 6 - Action Comics no 19, desenhada por Joe Schuster e publicada em dezembro de 1939.

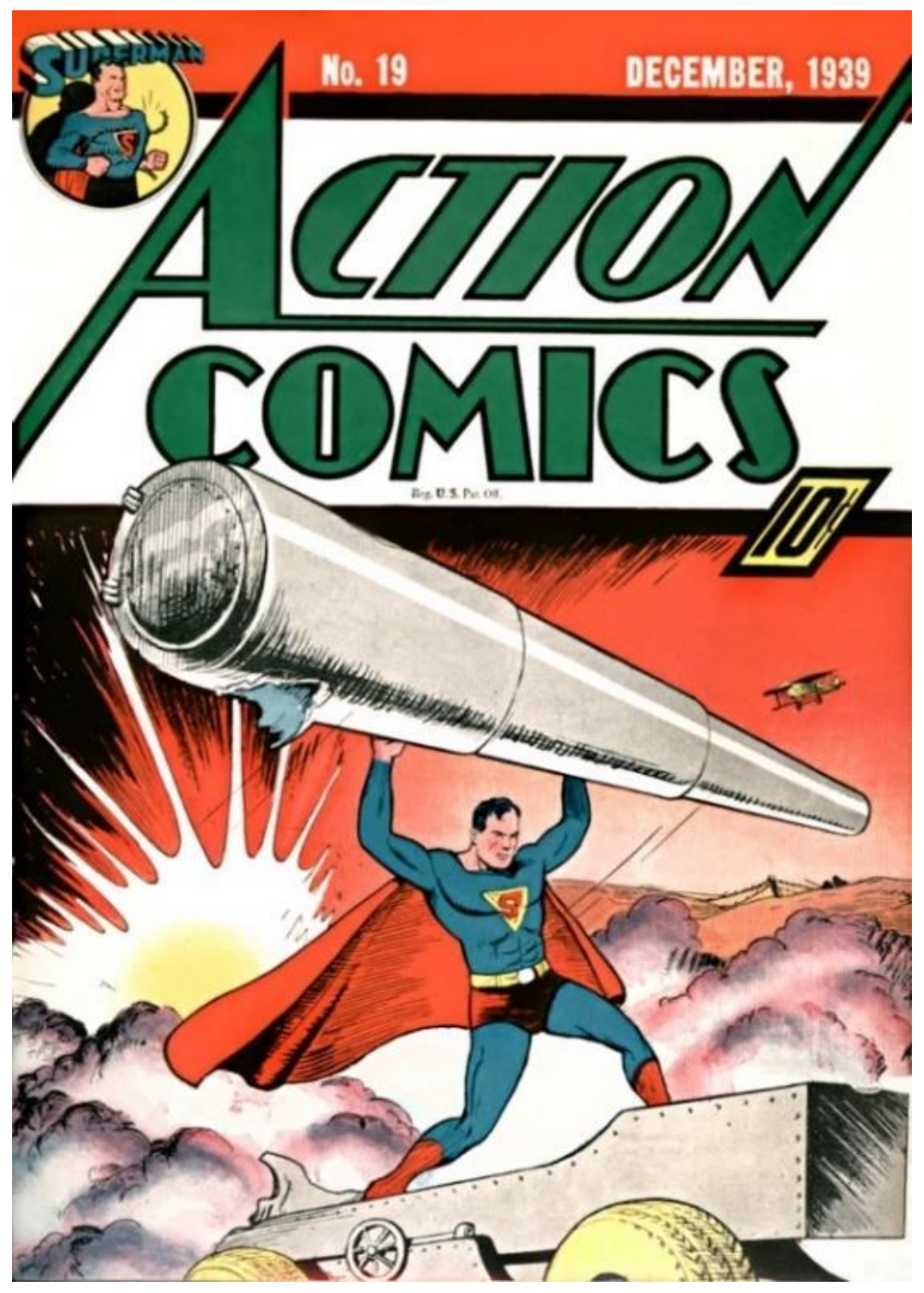

Fonte: DC Comics: the 75th anniversary poster book. Quirk Books: Philadelphia, 2010.

\footnotetext{
9 “O pastiche, como a paródia, é o imitar de um estilo único, peculiar ou idiossincrático, é o colocar de uma máscara linguística, é falar em uma linguagem morta. Mas é uma prática neutralizada de tal imitação, sem nenhum dos motivos inconfessos da paródia, sem o riso e sem a convicção de que, ao lado dessa linguagem anormal que se empresta por um momento, ainda existe uma saudável normalidade linguística. Desse modo, o pastiche é uma paródia branca, uma estátua sem olhos: está para a paródia assim como uma certa ironia branca - outro fenômeno moderno interessante e historicamente original - está para o que Wayne Booth chama de "ironias estáveis" do século XVIII. [...] o passado como "referente" é gradualmente colocado entre parênteses e depois desaparece de vez, deixando apenas textos em nossas mãos." (JAMESON, 1997, p. 44-46)
} 
Figura 7 - Quadros iniciais de I Guess.

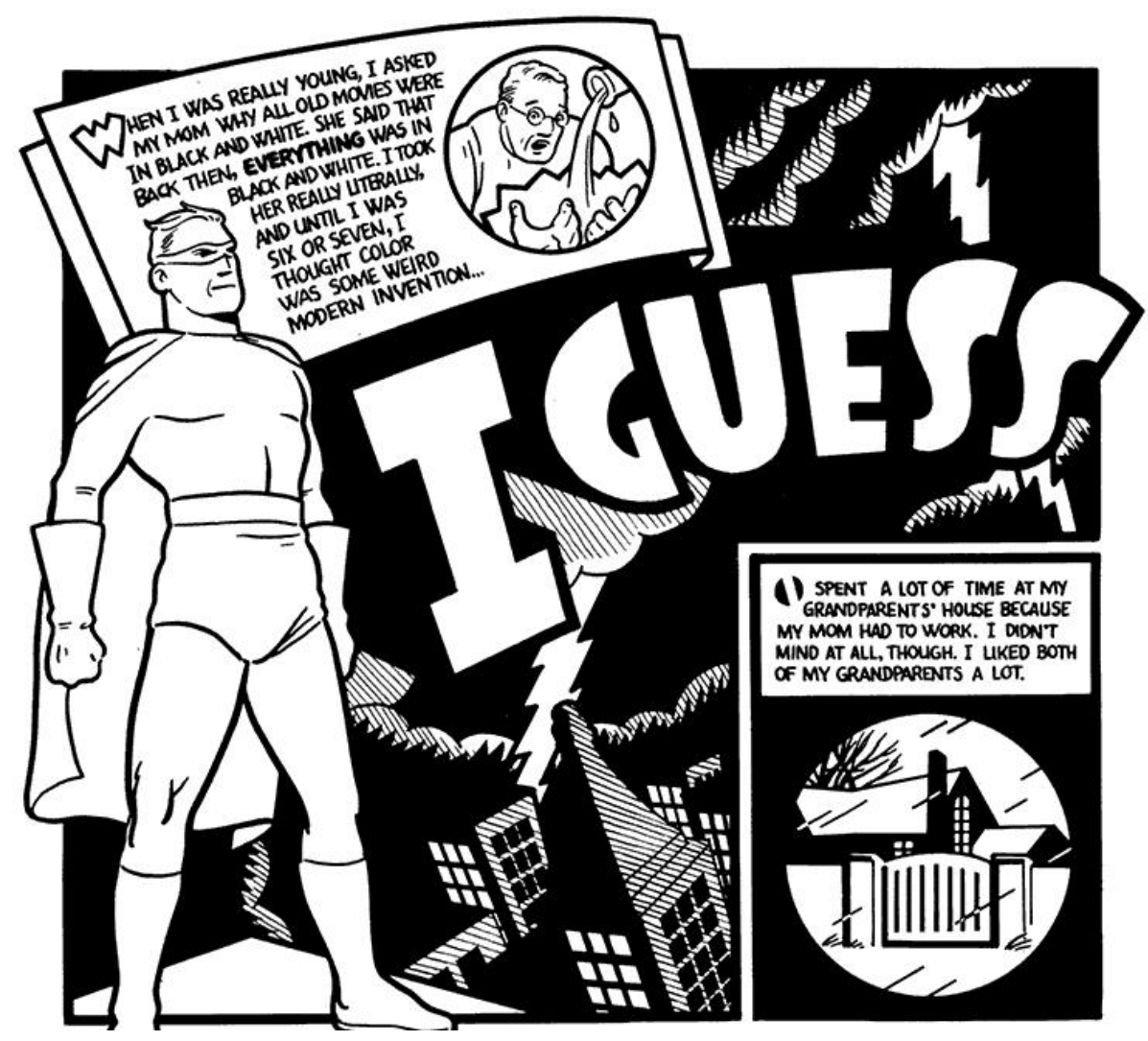

Fonte: WARE (1991)

Tradução nossa:

Quando eu era bem jovem, perguntei para a minha mãe por que todos os filmes antigos eram em preto e branco. Ela disse que antigamente tudo era em preto e branco. Eu a entendi literalmente e, até os meus seis ou sete anos, achava que a cor era uma espécie de estranha invenção moderna.

\section{EU ACHO QUE}

Eu passei muito tempo na casa do meu avô porque minha mãe tinha que trabalhar. Eu não me importava nem um pouco, no entanto. Eu gostava dos meus avós, muito.

I Guess (1991) apresenta uma discrepância (predominante na história) entre o elemento plástico e o verbal: este, uma narrativa autobiográfica que trata da infância de Ware. Há a imitação do estilo dos quadrinhos de super-heróis, mas a narrativa mostra que não é esse tipo de história que está sendo contada. A leitura do elemento verbal subverte as expectativas criadas pelo visual: a narração segue por caixas de texto, balões de fala e até mesmo o título não é um título de fato, mas parte da narração. À primeira vista, a leitura cria a impressão de verbal e visual como partes desconexas e separadas, mas a união de ambos cria uma nova camada de 
sentido: pelo uso da estética dos quadrinhos antigos, é estabelecida a relação entre o relato da infância do autor e o papel dos quadrinhos de super-heróis durante seus anos formativos.

Por ora foi observado como o autor utiliza suas referências estéticas na criação de seus quadrinhos, mas é também importante ressaltar outros elementos que fazem parte do seu experimentalismo na narrativa gráfica, com destaque à engenhosidade de Ware na construção plástica da narrativa. Para isso, são analisadas outras histórias, além da vista anteriormente.

Figura 8 - História presente em ACME Novelty Library 4 (1995)

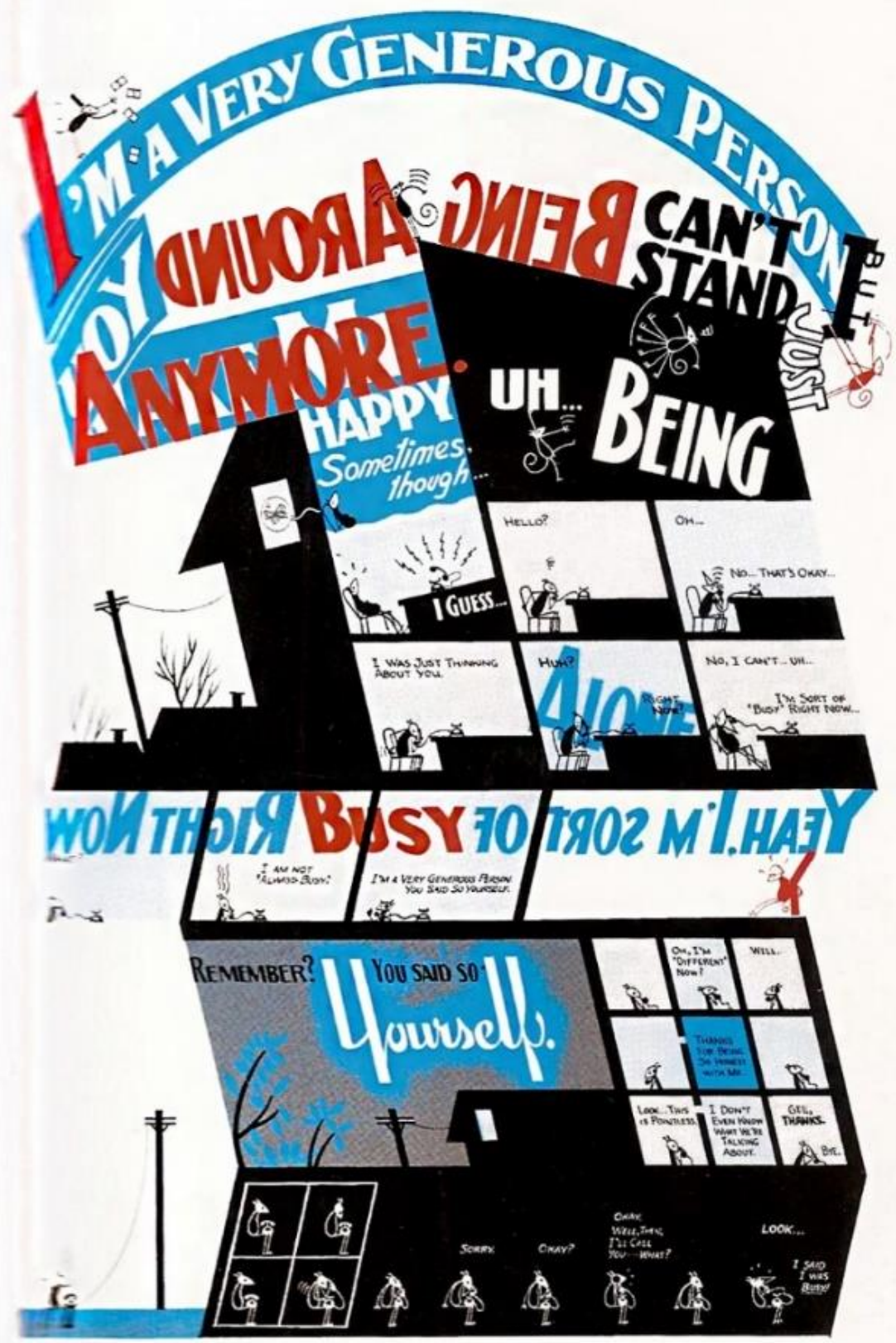

Fonte: WARE (1995) 
A história da Figura 8 aborda as dificuldades na relação dos personagens Quimby e Sparky. Quimby, o rato, por vezes ama ou odeia Sparky (uma referência a Krazy Kat, de Herriman): "Eu sou uma pessoa muito generosa, mas eu não aguento ficar perto de você agora", lê-se no início da história (tradução nossa). À narração é aplicado um tratamento plástico, que orienta a leitura e cria um caminho labiríntico pela página, aparecendo espelhado e com palavras se sobrepondo. Os sentimentos contraditórios de Quimby são evidenciados pela disposição da narração. Tomando o começo do quadrinho, "Eu sou uma pessoa muito generosa" aparece com orientação de leitura da esquerda para a direita, porém o trecho "mas eu não aguento ficar perto de você" é lido da direita para a esquerda, com as últimas palavras espelhadas.

I Guess, por sua vez, mostra a maneira pela qual Ware subverte o desenho das palavras no layout do quadrinho, criando títulos "falsos", por exemplo. A história na Figura 8 apresenta o verbal integrado às imagens, em uma disposição que mostra palavras espelhadas, se sobrepondo umas às outras e aos desenhos, criando um efeito de desorientação durante a leitura. O quadrinho convencional apresenta caixas de texto, balões de fala e onomatopeias como "lugares naturais" do verbal nas histórias (embora a onomatopeia encontre-se em um "meio termo" do verbal e visual, em muitos casos). Os elementos verbal e visual convivem no mesmo espaço, mas as partes são lidas, a princípio, separadamente. I Guess leva ao extremo esse caráter do quadrinho, ao colocar uma narração que parece a princípio incoerente com as imagens nos quadros, muitas vezes forçando a releitura de cada parte, além de dispor a narração em todos os espaços dedicados ao verbal, muitas vezes quebrando as frases, que começam em um balão e continuam em uma caixa de texto, por exemplo. Em contrapartida, a história na figura 8 mostra o verbal e o visual como inseparáveis, compondo uma única imagem. Ware joga, no plano da expressão, com a identificação vs. diferenciação do verbal (ancorado ou não no visual), criando diferentes efeitos de sentido ${ }^{10}$.

\footnotetext{
${ }^{10}$ A categoria identificação vs. diferenciação citada neste capítulo parte dos estudos de Pietroforte (2011, p. 64-70) sobre as articulações entre as semióticas verbal e plástica da poesia.
} 
Figura 9 - Página de Building Stories (2012).

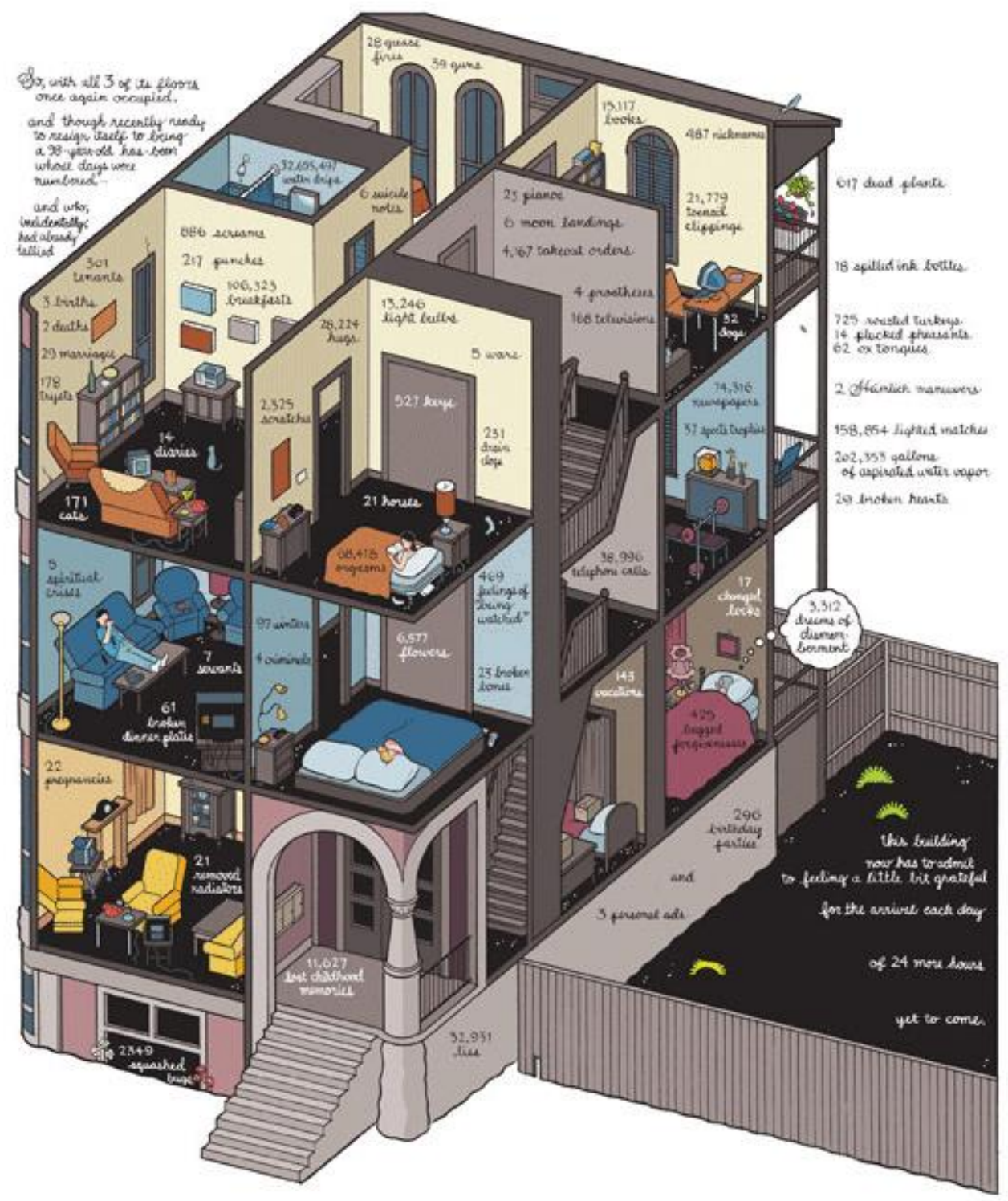

Fonte: WARE (2012)

À sofisticação diagramática de Ware, nota-se uma predileção pelo minimalismo no traço. Muitas histórias apresentam formas simplificadas (não raro seus personagens são geometrizados), cores chapadas e linhas de espessura equilibrada. Tal escolha estilística permite que o layout da página conduza a leitura (apesar de, em alguns casos, setas indicativas também serem utilizadas). Torna-se mais fácil, então, observar a presença de padrões na narrativa e as diferentes relações entre os elementos dispostos na página. O historiador Gene Kannenberg Jr. (2001, p. 176; tradução nossa) observa: 
Para Ware, o design se torna elemento narrativo crucial. O arranjo dos elementos visuais sobre a página cria a ilusão de teatro, de atuação da narrativa. Diferentemente do teatro, contudo, os quadrinhos permitem a apresentação simultânea de informações divergentes ou convergentes, por meio da disposição de diversos elementos visuais dentro do espaço unificador da página. Enquanto a maioria das narrativas de quadrinhos progride no tempo a cada quadro, muitas das páginas em um quadrinho de Ware justapõem diferentes sequências narrativas dentro de um espaço restrito.

A leitura do quadrinho, convencionalmente, é linear. McCloud (2005) apresenta os diversos tipos de transição, sendo elas entre momentos, cenas, temas, ações, aspectos ou, sem uma sequência lógica entre os quadros (denominada non sequitur). Em sua consideração sobre o quadro, Thierry Groensteen (2015, p. 45) aborda a relação de solidariedade entre quadros e a orientação da leitura:

a partir da localização respectiva das diferentes parcelas do multirrequadro que o leitor poderá deduzir o caminho a seguir para passar de um quadro a outro. A cada 'passo' a pergunta se torna cada vez mais visível: para onde dirijo meu olhar agora? Qual é o quadro seguinte, na ordem atribuída pelo programa narrativo?

A disposição dos quadros orienta a leitura, organizados no plano da página, sendo as coordenadas de posicionamento do quadro dependentes não somente da fragmentação do espaço, mas também do tempo, correspondendo a momentos particulares no desenrolar da narrativa e do processo de leitura (ibid., p. 45-46).

As histórias de Ware também apresentam sequências, mas sua organização no plano da página varia. Eis como exemplo a página de Building Stories presente na Figura 9: a página em questão faz parte de um livro e, portanto, se trata de um quadro de página simples. O trecho faz parte de uma história cuja introdução narra os pensamentos do edifício, suas impressões sobre seus moradores e sua própria história. Observando a leitura a cada página, ela é linear, com a transição ocorrendo de momento a momento: o edifício se percebendo vago, o instante em que uma nova moradora surge, a ponderação do prédio sobre as situações pelas quais passou nos seus 98 anos de existência. Cada página, no entanto, apresenta cenas que acompanham a narração, constituindo, teoricamente, outros quadros, porém dispostas dentro da mesma ilustração do prédio. A Figura 9 é exemplo disso: ao narrar e enumerar tudo que compôs a "história de vida" do edifício, a visão que se tem dele apresenta-se quase como uma "perspectiva explodida": nota-se a estrutura interna do prédio, seus cômodos e habitantes e, marcados nas paredes e pisos, seus eventos (“217 socos”, “425 pedidos de perdão”, "3.312 
sonhos de desmembramento", "23 pianos", etc.). A disposição dessas informações leva à apreensão da página como um todo e, depois, à observação de cada detalhe. Cria-se um efeito de sentido de totalidade: a distribuição planar dos elementos gráficos e verbais mostram aquilo que "constitui" o edifício como tal. Ware explora, no plano de expressão, com a diagramação permitindo a orientação linear vs. planar e seus efeitos de sentido, sendo aquela presente em I Guess e na história analisada no próximo capítulo.

As histórias de Ware têm como foco as relações humanas. Seus temas envolvem a solidão, a melancolia, a rotina, as desilusões e tensões da vida cotidiana. Em entrevista para Andrea Juno $^{11}$ (1997, apud KANNENBERG JR. 2001, p. 174, tradução nossa), Ware diz:

\begin{abstract}
Artistas como Dan Clowes, Jason Luttes e eu, estamos todos tentando contar um épico poderoso, profundamente envolvente, ricamente detalhado, com uma série de limeriques. Eu apenas tentei expandir as possibilidades para o formato [dos quadrinhos], para conseguir um pouco mais da sensação de uma experiência real.
\end{abstract}

O que Ware chama de "experiência real" não necessariamente refere-se à criação de efeitos de sentido de realidade sobre suas personagens - ou situações vividas efetivamente por alguém, à exceção de narrativas autobiográficas, como I Guess -, mas à representação de experiências e sensações com caráter humano que se concretiza pelo ato de leitura, sejam as histórias protagonizadas por um gato e um rato, um edifício, ou uma jovem solitária. É por meio da adoção ou subversão da linguagem dos quadrinhos e suas convenções, manipulando de maneira virtuosa o verbal e o visual, que o autor apresenta uma proposta de leitura alternativa, como demonstra-se a seguir.

\footnotetext{
${ }^{11}$ JUNO, Andrea. Dangerous drawings: interviews with comix and graphix artists. Nova York: Juno, 1997.
} 
2. A LEITURA ALTERNATIVA ANÁLISE DE HISTÓRIAS INDIVIDUAIS 


\subsection{Sobre autor, leitor e interações}

Um assunto de grande relevância nos estudos de comunicação sobre quadrinhos envolve a relação estabelecida entre leitor e autor. Isso porque a leitura de quadrinhos vai muito além do acompanhamento da sequência de imagens e textos: em uma dada história é possível perceber a iconicidade dos balões, as variações de tempo e espaço de acordo com o tamanho dos quadros, diferentes intensidades, intermediadas por determinadas escolhas caligráficas... É possível concluir, pois, que a leitura de quadrinhos demanda uma familiaridade com as suas convenções e uma espécie de "alfabetização" visual, adquirida pelo hábito. A familiaridade com o vocabulário dos quadrinhos pressupõe também o engajamento do seu leitor.

Scott McCloud trouxe um termo bastante utilizado para descrever o processo de interpretação dos quadrinhos: a "conclusão". Em Desvendando os Quadrinhos (McCLOUD, 2005, p. 65), é colocado que:

Figura 10
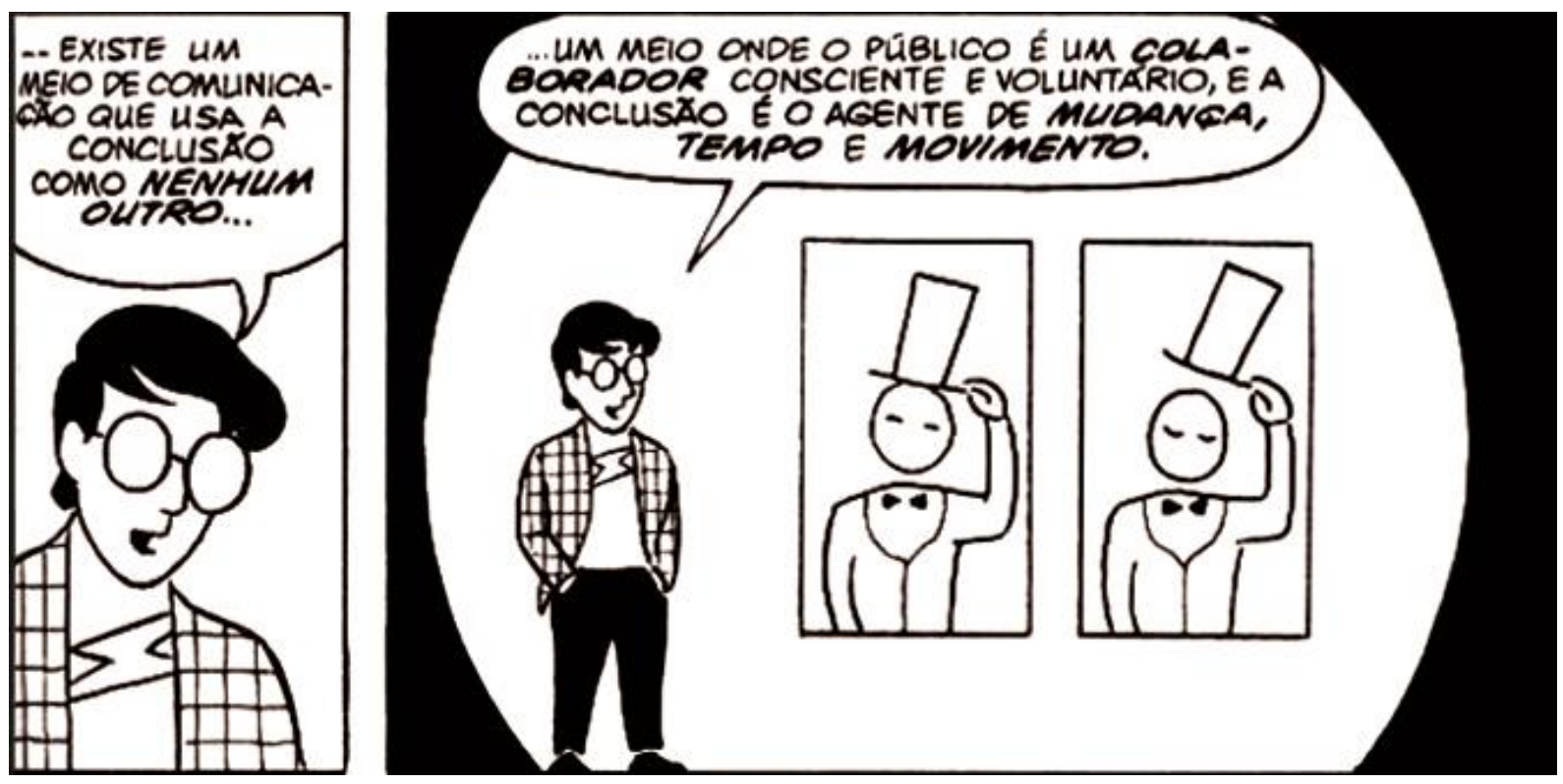

Fonte: McCLOUD, Scott. Desvendando os quadrinhos. Tradução de Helcio de Carvalho e Marisa do Nascimento Paro. São Paulo: Makron Books, 2005.

A conclusão é nome dado ao processo em que os fragmentos apresentados nos quadros são unidos e interpretados, por meio da colaboração do leitor, que preenche as lacunas durante a leitura dos quadros, conferindo-lhes sentido e coerência. No capítulo "Usando a sarjeta" (ibid., p. 60-93), McCloud aprofunda essa questão, apresentando variadas formas de transição 
de cenas (e enquadramentos) que criam efeitos de movimento, temporalidade, intensidade e até mesmo uma suposta aleatoriedade.

Will Eisner (2013), por sua vez, fala sobre a existência de um "contrato". Segundo Eisner, é necessário entendimento mútuo entre autor e leitor para que seja possível ler uma história. Ao primeiro cabe a responsabilidade de ser compreensível (ou seja, de saber como conduzir verbal e visualmente a sua narrativa) e, ao segundo, possuir o repertório necessário para que a interpretação seja possível. Além disso, o autor deve também reter a atenção do leitor e estabelecer um diálogo com o mesmo, permitindo a sua participação durante a leitura da história. A definição de Eisner aproxima-se do que Greimas e Courtés (2013, p. 167) chamam de competência semiótica: “o espaço das virtualidades semióticas, cuja atualização cabe à enunciação, é o lugar de residência das estruturas semionarrativas, formas que, ao se atualizarem como operações, constituem a competência semiótica do sujeito da enunciação".

Paul Gravett (2013) oferece uma complexificação dessa relação autor/leitor:

Há uma tensão contraditória no fazer e no ler quadrinhos. Por um lado, o criador de quadrinhos quer desacelerar o leitor, afim de que apreendam todo conteúdo narrativo relevante, tanto visual quanto verbal, contido em cada quadro. Por outro lado, o criador também quer motivar o leitor a deixar o quadro e mover-se ao próximo. Os "diretores" de quadrinhos possuem ferramentas e técnicas para alcançar ambos objetivos, guiando o "fluxo visual" ao estruturar imagens e dispor os textos para que fluam pela página, mas podem apenas fazê-lo para dirigir o leitor independente. Em vez de fraqueza no meio dos quadrinhos, isso é uma força. Contrariamente, as ferramentas manipuladoras de imagens moventes, que podem reter a atenção da audiência, quadrinhos são modestos em relação a seu tamanho e meios e têm de funcionar com muito mais intensidade sem sons, movimentos, música e atores emotivos e fotogênicos. Se quadrinhos, na maioria das vezes, são "só linhas no papel, pessoal!", como brincou certa vez Robert Crumb, é surpreendente que consigam funcionar e nos fazer sentir e se importar com eles. (GRAVETT, 2013, p. 53; tradução nossa).

Gravett observa a necessidade do autor de quadrinhos em "conduzir" do leitor, retendo a sua atenção e motivando-o a avançar com a história. Ao mesmo tempo, devido às suas restrições formais (falta de movimento, som, música, atores), os quadrinhos devem ser capazes de imprimir na narrativa variações críveis de intensidade, extensidade e paixões. Essa definição, curiosamente, aproxima-se mais daquilo que Greimas e Courtés (2013, p. 99) definem como contrato: 
[...] pode-se entender por contrato o fato de estabelecer, de "contrair" uma relação intersubjetiva que tem por efeito modificar o estatuto (o ser e/ou o parecer) de cada um dos sujeitos em presença. Sem que se possa dar uma definição rigorosa dessa noção intuitiva, trata-se de propor o termo contrato, a fim de determinar progressivamente as condições mínimas, nas quais se efetua a "tomada de contato" de um sujeito para com o outro, condições que poderão ser consideradas pressupostos do estabelecimento da estrutura da comunicação semiótica. [...] O fato é que o estabelecimento da estrutura intersubjetiva é, por um lado, um abertura sobre o futuro e sobre as possibilidades da ação e, por outro, uma coerção que limita de certa forma a liberdade de cada um dos sujeitos.

O contrato fiduciário é estabelecido entre dois sujeitos, destinador e destinatário. Para admiti-lo a autor e leitor, é necessário, no entanto, levar em conta que este é um nível de pertinência distinto daquele que envolve o contrato entre sujeitos dentro de uma narrativa. $\mathrm{O}$ que se considera neste caso, pois, será um fazer social como o recorte de tex to. Isto posto, Fiorin (2009, p. 56) explica que autor e leitor são enunciador e enunciatário. Ele observa, no entanto, que não se tratam do leitor e autor "de carne e osso", mas sim aqueles implícitos, a imagem de cada um, construída pelo texto. Greimas e Courtés (2013, p. 171) colocam que "o enunciatário não é apenas destinatário da comunicação, mas também sujeito produtor do discurso, por ser a 'leitura' um ato de linguagem (um ato de significar) da mesma maneira que a produção do discurso propriamente dito". Por esse motivo, emprega-se o termo "sujeito da enunciação" para cobrir as duas posições actanciais: enunciador e enunciatário.

Eisner, McCloud e Gravett definem a leitura dos quadrinhos como operação que não é unilateral: os sujeitos da enunciação devem possuir competência semiótica (saber, poder) e entre eles há um contrato fiduciário, no qual o primeiro executa um fazer persuasivo (fazercrer) e o segundo, um fazer interpretativo (crer). Há, portanto, um crer que se instala nas duas extremidades do canal de comunicação, estabelecendo um entendimento tácito entre enunciador e enunciatário.

A posse do repertório de quadrinhos permite ao leitor interpretar as histórias e envolverse com as mesmas; aos autores, o domínio do vocabulário verbo-visual dos quadrinhos, das estratégias narrativas e seus potenciais efeitos de sentido, abre espaço para a experimentação com os elementos constituintes e convencionais dos quadrinhos. É pela experimentação que são possíveis novas propostas de leitura e a ampliação das possibilidades de interpretação das suas narrativas. 
A história a ser analisada a seguir é um bom exemplo de como Chris Ware oferece uma complexificação da figura do leitor. Na narrativa, a protagonista é apresentada em um momento de dúvida e angústia em sua vida. Para representar essa situação, a história encontra-se impressa em uma tira de papel, frente e verso, sem indicação de onde a história começa ou termina. Isso permite ao leitor iniciar a leitura a partir de dois pontos distintos, sem encontrar um elemento que indique o "fim". O efeito que se obtém é o de uma leitura circular, com o movimento pendular da protagonista entre dois pontos.

\subsubsection{A semiótica do texto verbal}

Visto que a história a ser analisada não apresenta uma ordem de leitura definida, a escolha de um ponto de partida se faz necessária. Sendo assim, optar-se-á pela leitura que começa na Figura 11 e segue na Figura 12, conforme aparece a seguir: 

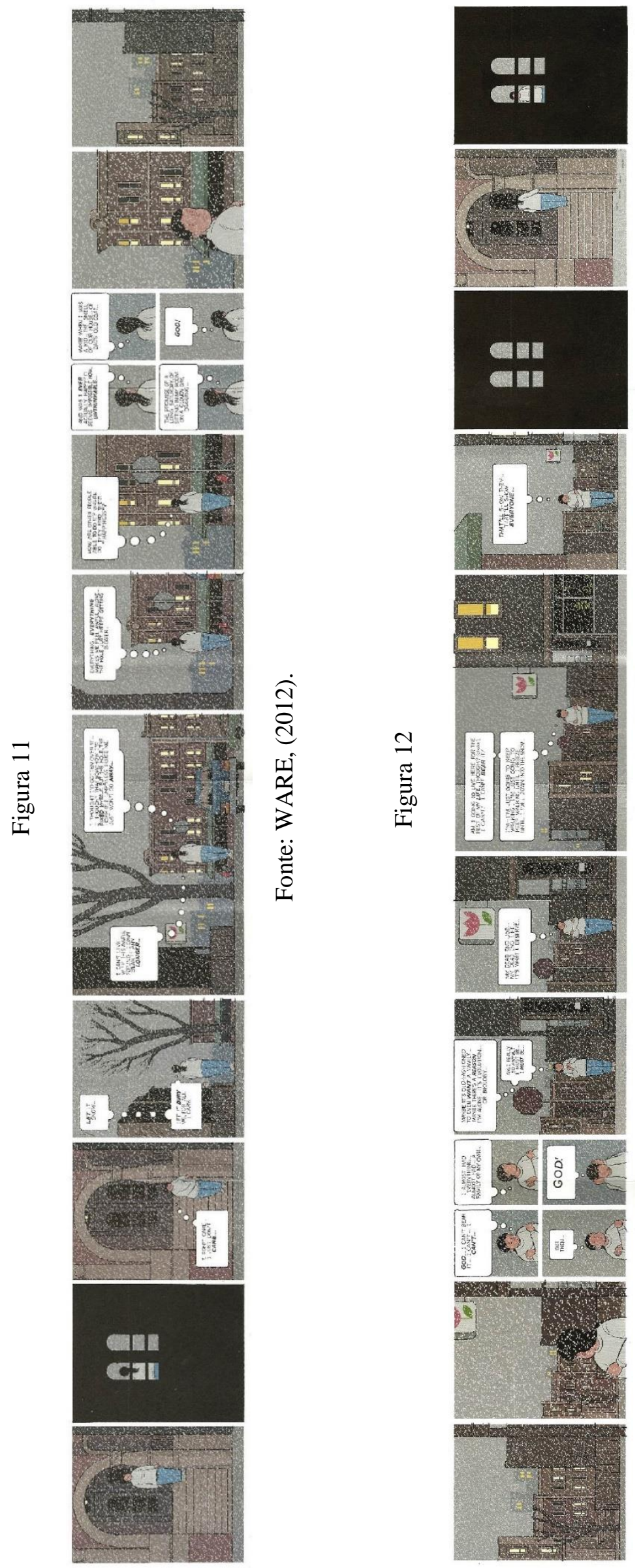

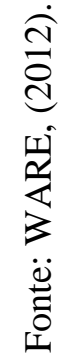
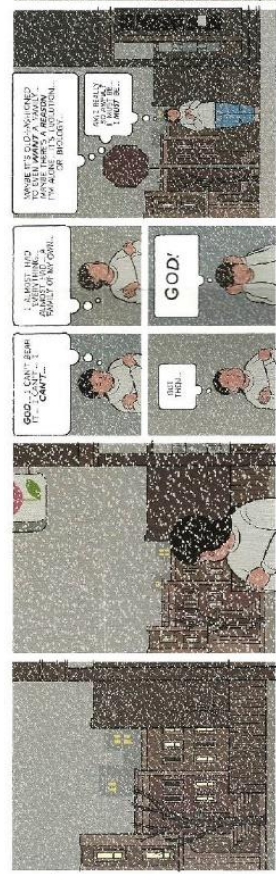
A narrativa da história é simples: a protagonista encontra-se na rua, andando entre seu prédio - que tem as luzes do hall de entrada apagadas - e outros edifícios adiante - que possuem janelas iluminadas -. Por toda a história, a insatisfação do sujeito é manifestada: ela não está feliz com a sua vida, pondera sobre a morte, sobre seu sentimento de solidão, sua infância, sua falta de perspectivas para o futuro e sobre a possibilidade de, como outras pessoas, "encontrar" a felicidade. Seu sentimento de frustração alterna-se com pensamentos voltados à "busca" da felicidade, projetados naquilo que ela acredita serem as soluções de sua infelicidade: um emprego melhor, uma família.

É possível perceber, pois, que o sujeito protagonista se encontra em uma crise de identidade. A busca pela identidade carece de convicção, com a protagonista em conflito sobre seus desejos e aquilo que ela mesma observa serem também valores normativos da sociedade. O nível das estruturas fundamentais apresenta a oposição semântica que constrói o sentido do texto. Aqui, a categoria semântica fundamental é identidade vs. alteridade. A identidade aparece euforizada, enquanto a alteridade é disfórica.
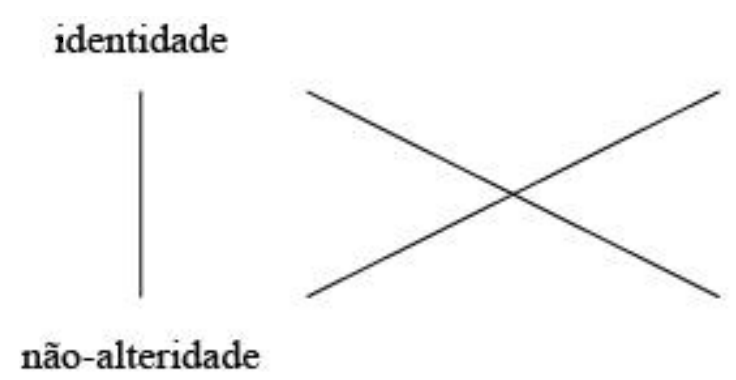

não-alteridade

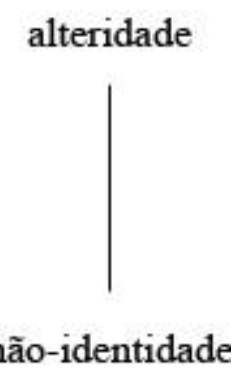

não-identidade

A categoria permite dois percursos possíveis: o que parte da alteridade, a nega e afirma a identidade; e o contrário, que parte da identidade, a nega e afirma a alteridade, aparecendo respectivamente nas Figuras 11 e 12 como:

$$
\begin{gathered}
\text { alteridade } \rightarrow \text { não-alteridade } \rightarrow \text { identidade } \\
\text { identidade } \rightarrow \text { não-identidade } \rightarrow \text { alteridade }
\end{gathered}
$$

$\mathrm{O}$ primeiro percurso realizado (Figura 11) é o da alteridade $\rightarrow$ não-alteridade $\rightarrow$ identidade. A alteridade é afirmada do terceiro ao quinto quadro (visto que não há falas nos dois primeiros), nas cenas que mostram a protagonista afirmando sua insatisfação, seus sentimentos suicidas e a constatação de que, apesar dos seus esforços, ela é incapaz de se desvencilhar do sentimento de "vazio" que a domina: "eu achei que teria superado... Eu achei 
que eu tivesse de alguma forma me consertado, mas esse buraco, esse vazio horrível dentro de mim apenas não vai embora..." (tradução nossa).

No sexto e sétimo quadros, a alteridade é negada. $\mathrm{O}$ sujeito reflete sobre o que não funcionou para mudar a sua situação, levantando em seguida a pergunta "como outras pessoas conseguem? Onde elas encontram a sua 'felicidade'?". A partir desse ponto, do oitavo ao décimo primeiro quadros (os menores, agrupados), que a protagonista, motivada pela ideia de felicidade, pensa no passado: "e eu fui alguma vez verdadeiramente feliz? Parece impossível agora... Impensável”, "talvez quando eu era criança... O cheiro da nossa casa... Do velho casaco do papai" e "a promessa de um longo sábado, sentada no meu quarto em um dia nublado, desenhando...". A identidade é afirmada pela nostalgia: as memórias da infância e sua associação a elementos ligados à vida em família.

Figura 13 - quinto quadro da Figura 11

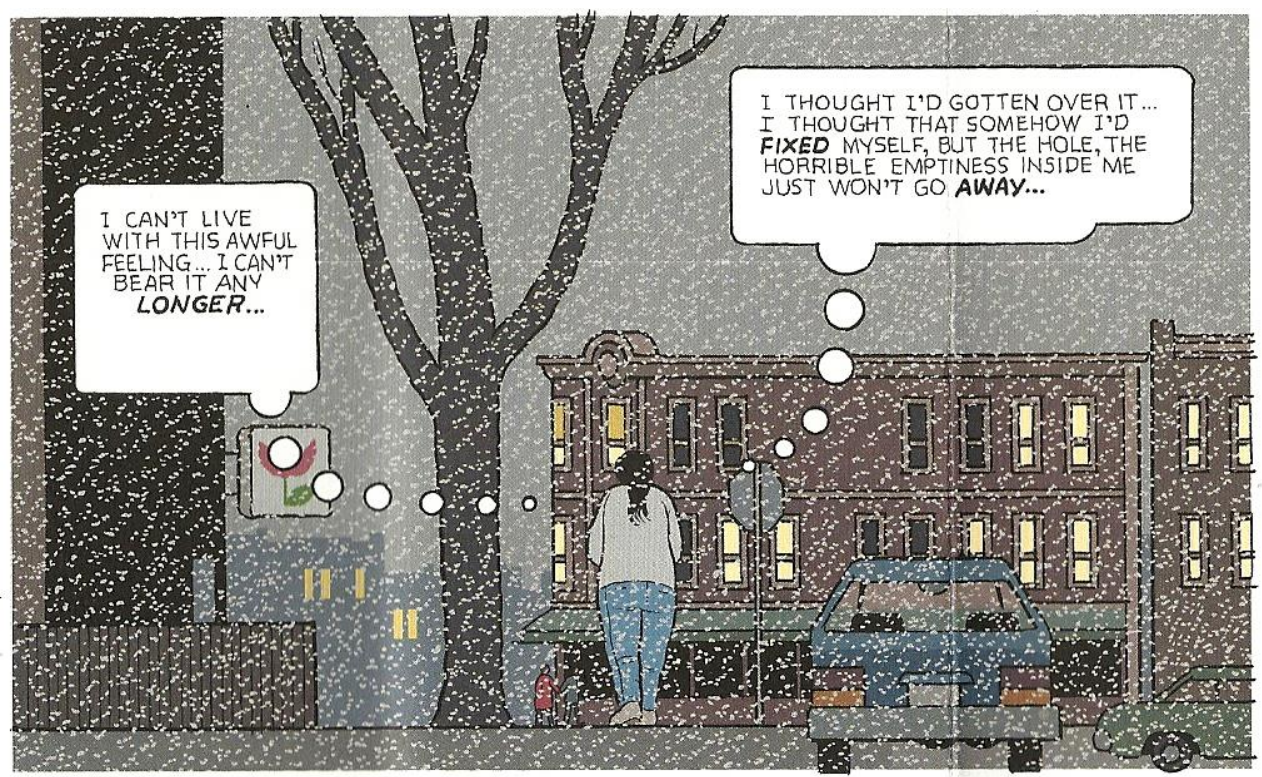

Fonte: WARE (2012)

Tradução nossa:

“Eu não posso viver mais com esse sentimento horrível... Eu não consigo mais aguentar..."

"Eu achei que teria superado... Eu achei que se eu tivesse de alguma forma me consertado, mas esse buraco, este vazio horrivel dentro de mim apenas não vai embora..." 
Figura 14 - quadros 7 a 11 da Figura 11
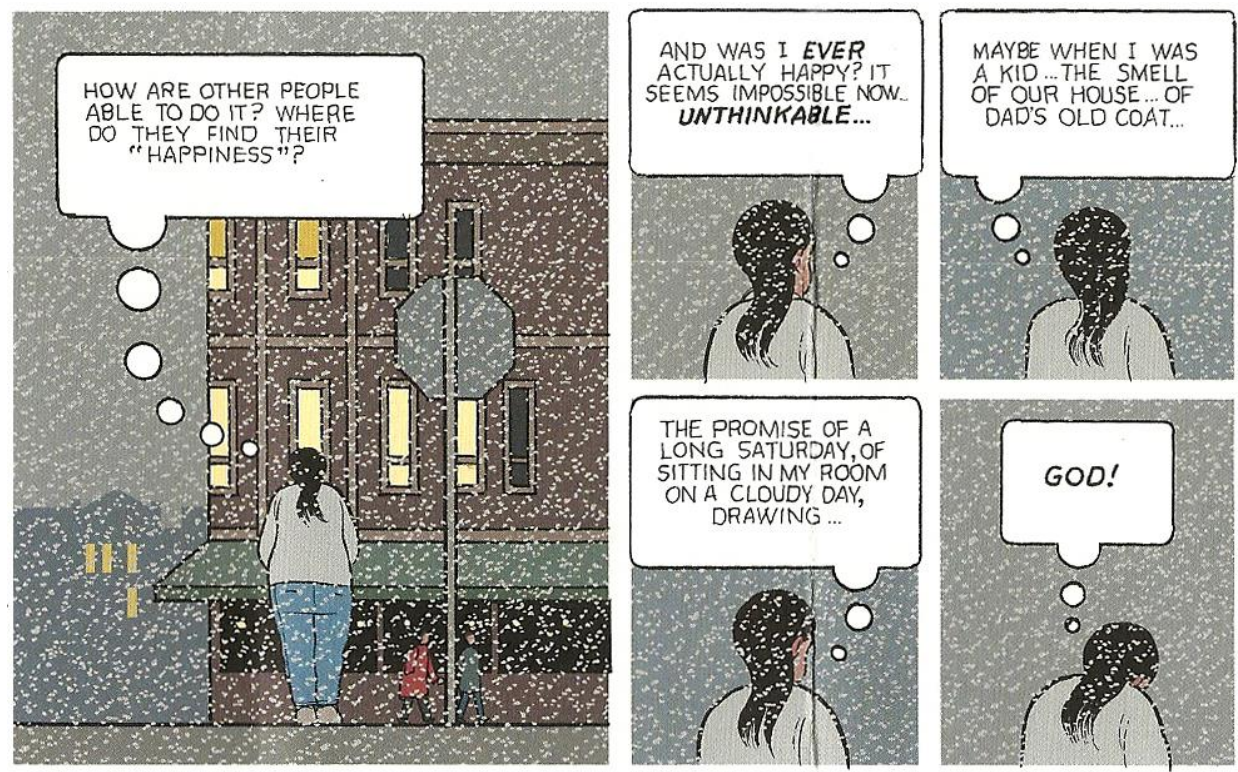

Fonte: WARE (2012)

\section{Tradução nossa:}

"Como outras pessoas conseguem? Onde elas acham a sua "felicidade"?"

"E eu fui alguma vez verdadeiramente feliz? Parece impossível agora... Impensável..."

"Talvez quando eu era criança... O cheiro da nossa casa... Do velho casaco do papai..."

“A promessa de um longo sábado, sentada no meu quarto em um dia nublado, desenhando..."

\section{"DEUS!"}

Do outro lado (Figura 12), verifica-se o percurso identidade $\rightarrow$ não-identidade $\rightarrow$ alteridade. Novamente, os dois quadros iniciais não apresentam falas. $\mathrm{O}$ grupo de quadros pequenos (terceiro ao sexto) mostram a manifestação da frustração do sujeito, ao lembrar-se que "eu quase tive tudo... Quase tive uma família minha...", "mas então...”. Ela não completa o pensamento, encerrando com a mesma exclamação de frustração da quadra anterior ("Deus!"). Aqui, a identidade é afirmada nas considerações que trazem essa possibilidade de encontrar "um lugar no mundo", ligadas à chance (perdida) de construir uma família. 
Figura 15 - quadros 3 a 7 da Figura 12
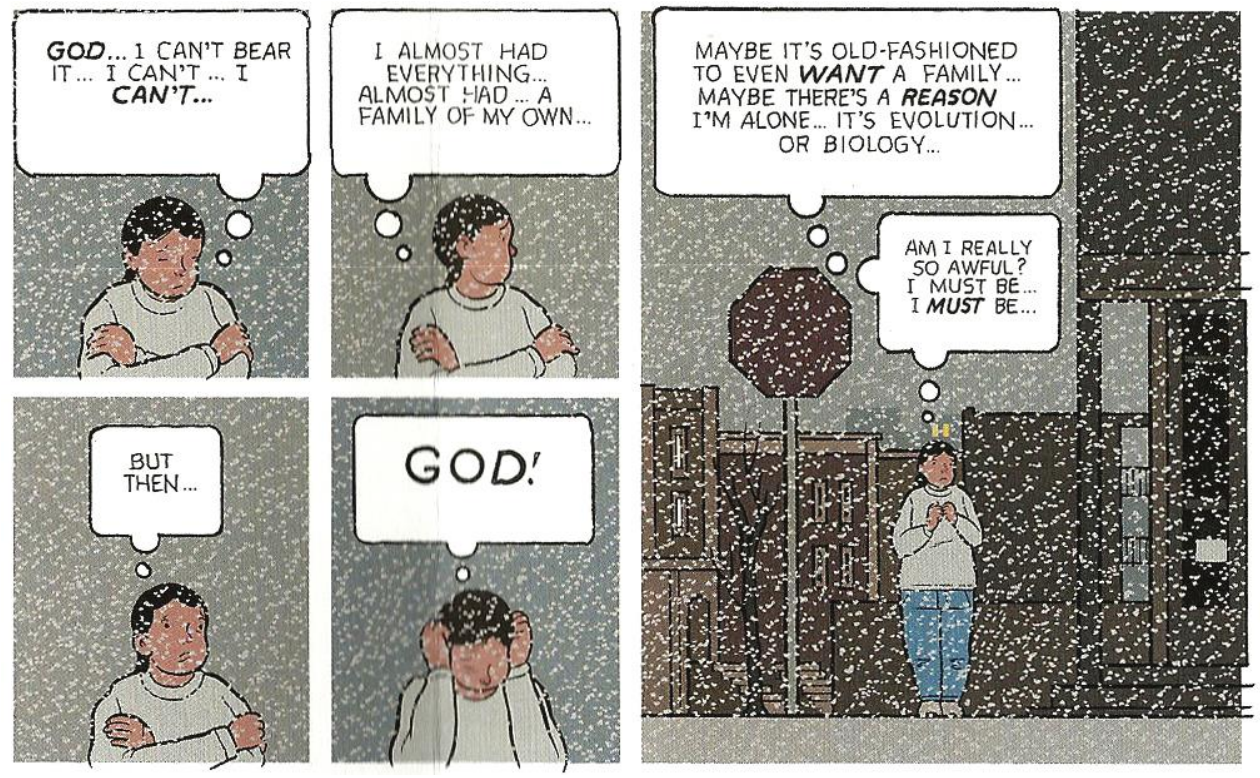

Fonte: WARE (2012)

\section{Tradução nossa:}

"Deus.. Eu não posso mais aguentar... Eu não posso.. Não posso..."

"Eu quase tive tudo... Quase tive... Uma familia minha..."

"Mas então..."

"Deus!"

"Talvez seja antiquado até mesmo querer uma família... Talvez exista uma razão para eu ser sozinha... É evolução ou biologia..."

"Eu sou mesmo tão horrivel? Eu devo ser... Eu devo ser..."

O sétimo quadro, porém, apresenta a protagonista questionando a validade da própria ideia de querer ter uma família e, portanto, negando a identidade. Por fim, a alteridade é afirmada quando o sentimento de insatisfação volta a dominar o sujeito, assim como os pensamentos ligados à morte (“eu... Eu vou apenas continuar andando até eu congelar... Até eu cair na neve...”).

É possível notar, portanto, que em ambos os lados a ideia da felicidade mostra-se sempre ligada ao passado, à memória. Uma vez que parece impossível obter aquilo que deseja no tempo presente, ela tenta recuperar a conjunção com o objeto de valor por meio de suas lembranças. Uma possibilidade de futuro nunca se apresenta como algo alcançável, mas há um reiterado recrudescimento do passado (ele, também distante), ora como nostalgia, ora como 
arrependimento. A sensação de impotência da protagonista, ligada à ideia de felicidade que pode ser vivida como lembrança, acentua o sentimento de frustração presente em toda a história.

O sujeito apresenta-se em toda a narrativa em disjunção com o objeto de valor felicidade, figurativizado por elementos como "família”, "papai” e "casa”, por exemplo. É possível perceber que a protagonista é manipulada por seus desejos de transformar sua vida, com a qual está insatisfeita. Ela anseia pelos valores de uma identidade socialmente aceita ("família", conforto, segurança, companhia), enquanto reflete sobre a sua situação presente, com valores que não a agradam (solidão, "trabalho que não leva a lugar nenhum", vazio existencial, insegurança). O sujeito deseja a transformação, mas esta nunca acontece, independente da ordem que se leia a história.

É possível identificar uma manipulação, ainda que ela não esteja explícita. Por um lado, pode-se considerar que o sujeito apresenta um querer: o desejo de ter um parceiro, construir uma família, mudar de emprego. Há aqui sincretismo actancial, com a protagonista como destinador e sujeito da manipulação. Este sujeito, no entanto, apesar de aparecer manipulado por si mesmo, reflete valores normativos da sociedade (considerada de forma abstrata: "eles", "todo mundo"). Isso fica mais claro no verso na história (Figura 12): ao colocar que "talvez seja antiquado" desejar uma família, é levantada a dúvida se aquilo que a manipula parte de um querer seu, ou do dever que lhe é imposto por uma sociedade que atribui valor à mulher quando ela assume seu papel de gênero normativo de mãe e esposa. Esses valores, percebe-se, apresentam-se internalizados a ponto de não colocarem a execução desse fazer como uma obrigação, ou seja: são tênues as fronteiras estabelecidas entre o querer e o dever, suscitando a dúvida da protagonista. Essa dúvida contribui também na sua falta de convicção para buscar efetivamente aquilo que acredita "desejar", marcando a crise de sua identidade enquanto mulher ${ }^{12}$.

\footnotetext{
${ }^{12}$ Camargo (2013) explora a temática de gênero como pertencente ao discurso, mais especificamente à semântica discursiva, ou seja, discursos sobre gênero pertencem à linguagem e são construídos por ela, não havendo um referente natural no mundo. $\mathrm{O}$ termo gênero, portanto, apresenta-se no pensamento científico como construção social, pertencente à cultura, enquanto o sexo pertence ao campo semântico da natureza. A partir de dois momentos - a publicação de O segundo sexo (1967) de Simone de Beauvoir e Gender trouble (1990), de Judith Butler -, Camargo explora a problemática da questão natureza vs. cultura na definição de gênero, observando que "os efeitos de sentido produzidos pela temática de gênero que constroem diversos tipos de narrativa em diferentes culturas. Se depois do séc. XVIII é predominante a leitura prática e o efeito referencial na temática de gênero nas culturas ocidentais, tal acontecimento não pressupõe referentes que definem tais discursos, ao contrário, são os discursos que
} 
O sujeito se encontra em disjunção com os valores "família", "infância", causando-lhe tristeza. Para seguir seu percurso narrativo, no entanto, ela precisa agir sobre o mundo, mas se encontra incapaz disso. A base do seu problema está na sua incapacidade de desenvolver a competência, ou seja, ela precisa saber e poder. Ela é, portanto, um sujeito virtual (ela possui o querer e o dever) durante toda a narrativa. Há a possibilidade do fazer, mas o sujeito é incapaz de atualizar a sua competência e executar a performance. O que se observa, no entanto, é que a aquisição dos valores é colocada como dependente da interferência de outros sujeitos (um parceiro com quem tenha filhos ou que lhe faça companhia, uma empresa ou cliente que lhe ofereça um trabalho melhor...). A agência da protagonista é, assim, negada, sendo ela dependente da ação de outros sujeitos, externos (ou assim ela acredita).

Em seu momento de dúvida, é apresentado outro caminho possível. A protagonista tem a opção de abdicar desses valores, euforizando aqueles que fazem parte da sua vida presente, mas percebe-se que ela não está inclinada a isso; entre outros motivos, porque sua angústia e a possível pressão social exigem assumir a sua identidade feminina, na qual a independência e a prosperidade profissional não são bem vistas e a felicidade feminina é tida como dependente da subjugação da identidade do indivíduo em relação aos valores sociais normativos. Ao ponderar sobre o que ela diz "merecer", é possível identificar a sanção negativa que o sujeito executa sobre si, sobre sua incapacidade de realizar o fazer, cumprir o contrato estabelecido na etapa de manipulação: observa-se o seu "fracasso" por não cumprir o contrato social de estabelecer família e assumir seu papel como mulher. Dessa maneira, ela se vê merecedora de valores indesejáveis, como a solidão.

\subsubsection{A semiótica do texto plástico}

O movimento da protagonista, conforme foi explicado anteriormente, a mostra afastando-se do edifício que apresenta o hall às escuras e indo em direção aos prédios com as janelas iluminadas; ou então fazendo o caminho inverso, se afastando das luzes e indo ao edifício:

elaboram e significam o sistema de gênero e produzem uma aparência de substância natural. Contudo, não há nada natural no sistema de gênero que não tenha sido naturalizado pela linguagem" (p. 91-92). 
Figura 11 -alteridade $\rightarrow$ não-alteridade $\rightarrow$ identidade

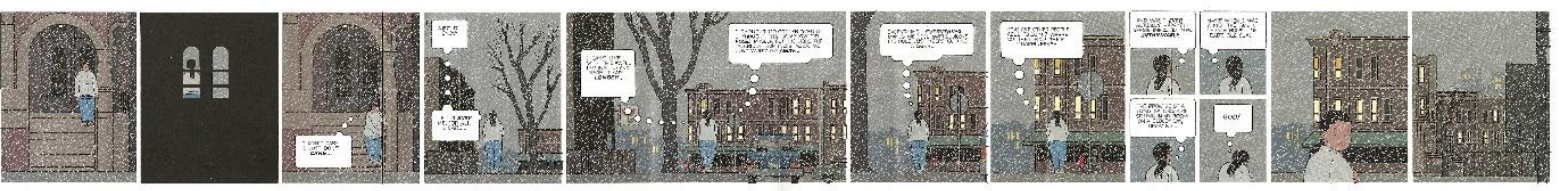

Fonte: WARE (2012)

Figura 12 -identidade $\rightarrow$ não-identidade $\rightarrow$ alteridade

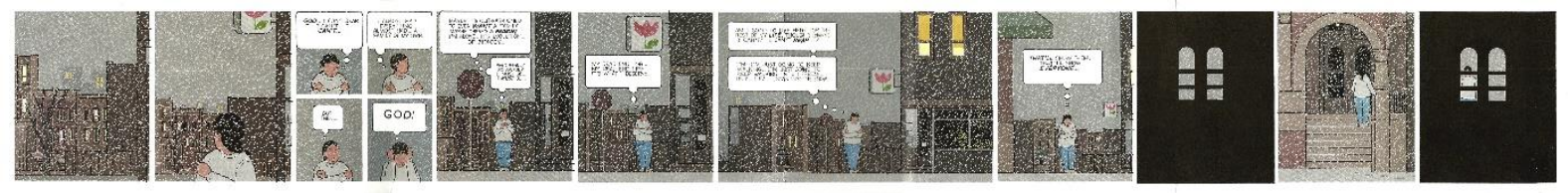

Fonte: WARE (2012)

Há um elemento cromático predominante no texto. O quadrinho apresenta, em quase sua totalidade, tons dessaturados, neutros e frios: o céu é cinza; os marrons, azuis e vermelhos são desbotados, oferecendo variações muito sutis de tonalidade. Mesmo a protagonista veste roupas em tons desbotados de cinza e azul e, não fossem os traços de contorno do desenho, seu corpo se perderia em meio ao cenário.

A escuridão do hall interno do prédio se distingue da neutralidade dos tons da rua, assim como as janelas iluminadas dos edifícios, em tons de amarelo claro. A escuridão é mostrada do espaço interior do prédio para fora: a massa de cor preta engloba as janelas da porta de entrada do edifício, emoldurando a visão do espaço exterior. A luz, por sua vez, é englobada pelo espaço da rua, em massas de cor que apresentam à sua volta o cenário. A categoria do plano de conteúdo identidade vs. alteridade é expressada pela categoria cromática claro vs. escuro. Outra relação estabelecida envolve a maneira pela qual elementos cromáticos estão dispostos na composição: no caso, o claro está englobado pelo cenário e o escuro é englobante da rua. Isso estabelece uma relação semissimbólica, em que:

identidade vs. alteridade

claro englobado vs. escuro englobante 
Figura 16 - O claro englobado (em destaque) e o escuro englobante.
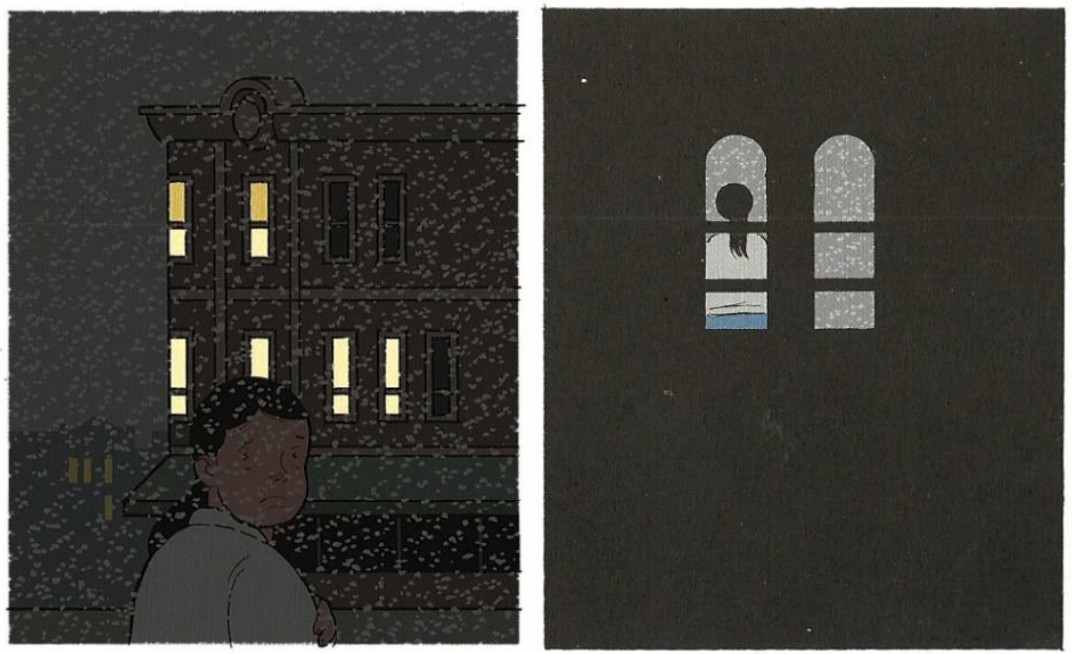

Fonte: WARE (2012). Montagem da autora.

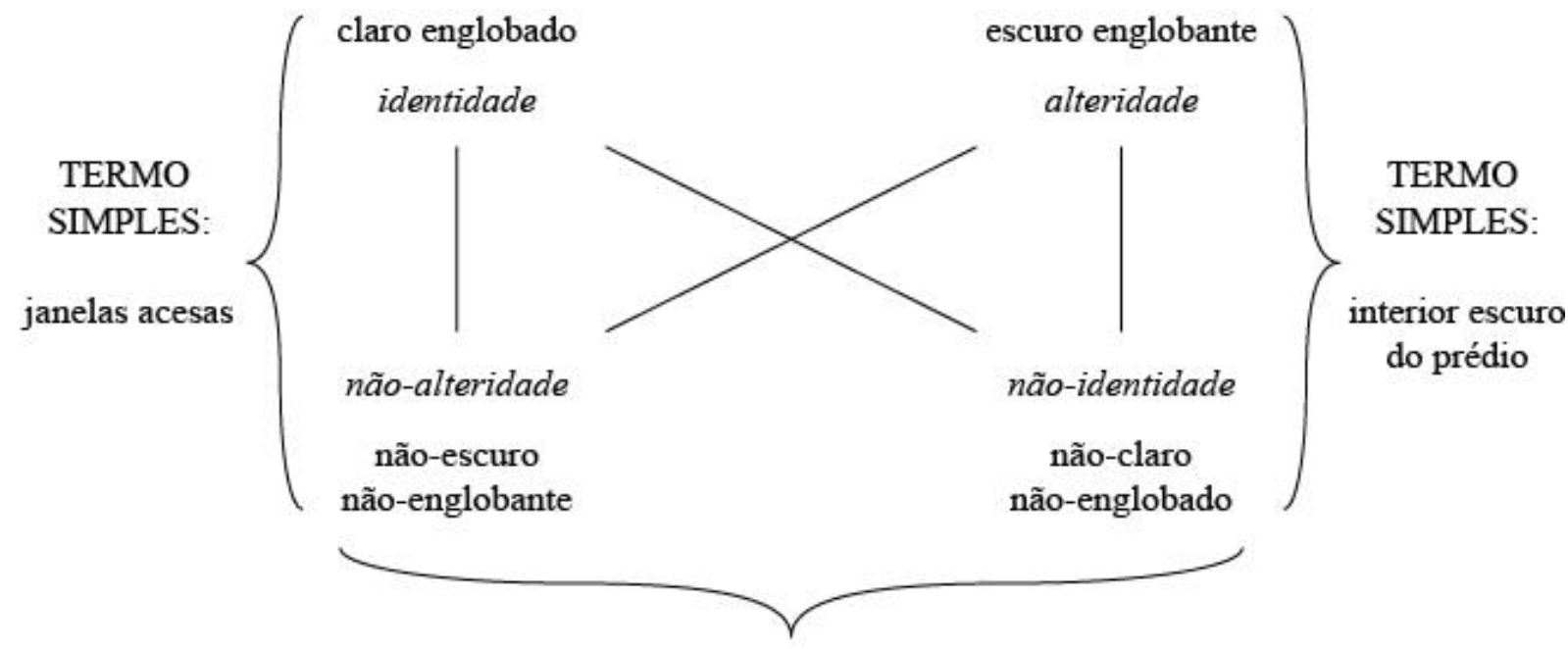

TERMO NEUTRO:

rua cinzenta

Em ambos os casos, nota-se que o movimento da protagonista nunca alcança de fato as luzes ou a escuridão. Seu movimento é pendular, indo de um polo ao outro durante toda a história, mantendo-a em uma zona neutra: a rua, que apresenta tons dessaturados, próximos ao cinza.

A neutralidade (o não-claro não-englobado e o não-escuro não-englobante) se mostra, portanto, mais próxima da não-identidade e da não-alteridade. Isso retoma o que foi colocado, sobre a falta de convicção do sujeito durante a narrativa: apesar de sua tristeza e insatisfação, a protagonista não se compromete de fato com nenhuma das opções que tem diante de si. Os polos se mostram nítidos, mas ela é incapaz de agir sobre o mundo e transformar a sua situação 
presente, seja por medo, dúvida ou por considerar que a mudança só seria possível por meio da interferência de sujeitos externos. Ela vai e volta pelos mesmos caminhos e se mostra presa em sua própria indefinição.

\subsubsection{Uma segunda categoria semântica: vida vs. morte}

O leitor acompanha, durante a narrativa, apenas os pensamentos da protagonista. Tomando como ponto de partida o lado da história apresentado na Figura 11, o sujeito expressa sua absoluta frustração, dizendo coisas como "Deixe que neve... Deixe que me enterre, eu não ligo...”. Os pensamentos suicidas se mostram mais concentrados nos quadros próximos ao centro: no quarto e quinto quadros da Figura 11 e no sexto e sétimo quadros da Figura 12. Neste ponto é necessário considerar uma segunda categoria do plano de conteúdo apresentada pelo texto: vida vs. morte.

Ao ponderar o suicídio, a protagonista imagina a possibilidade de morrer de frio, sendo soterrada pela neve. Interessante observar que, no contexto da história, a morte é euforizada: seria uma possível "solução" para a situação do sujeito e uma maneira de não precisar lidar, portanto, com seus sentimentos de infelicidade e angústia. Assim, espaço coberto (seja o interior do seu prédio ou as janelas acesas que indicam apartamentos habitados) e o calor estão ligados à vida, enquanto o desconforto, a neve e o frio estão ligados à morte.

Figura 17
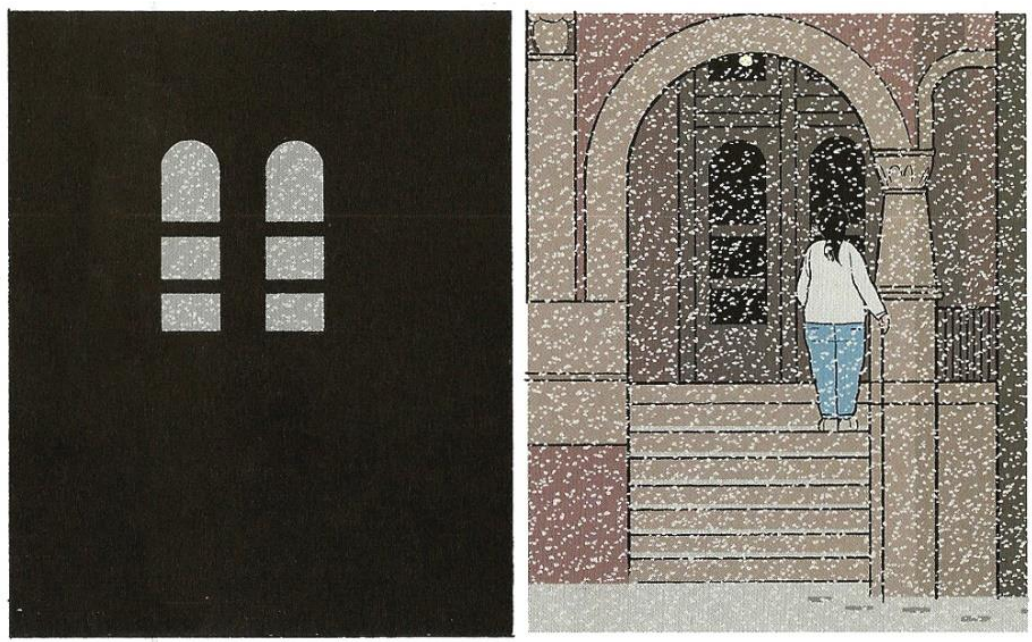

Fonte: WARE (2012) 
Plasticamente, a oposição se mostra nos contornos. Observando a imagem acima, é possível perceber que o primeiro quadro apresenta os contornos definidos da massa de cor preta que forma o recorte da porta do prédio. No segundo quadro, no entanto, é possível perceber como a neve forma uma textura sobreposta à visão da rua, sem um contorno definido, cobrindo e descobrindo partes da imagem, inclusive da própria protagonista. Os contornos aparecem mais definidos, no entanto, nas janelas acesas dos prédios à frente. A neve não aparece sobre eles, os destacando da textura formada ao redor.

Figura 18

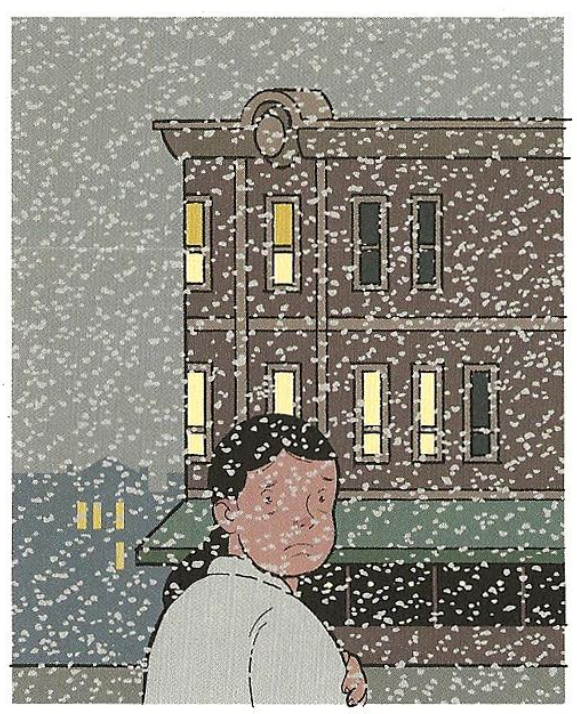

Fonte: WARE (2012)

É estabelecida, assim, a seguinte categoria eidética:

vida vs. morte $\rightarrow$ definido vs. difuso 


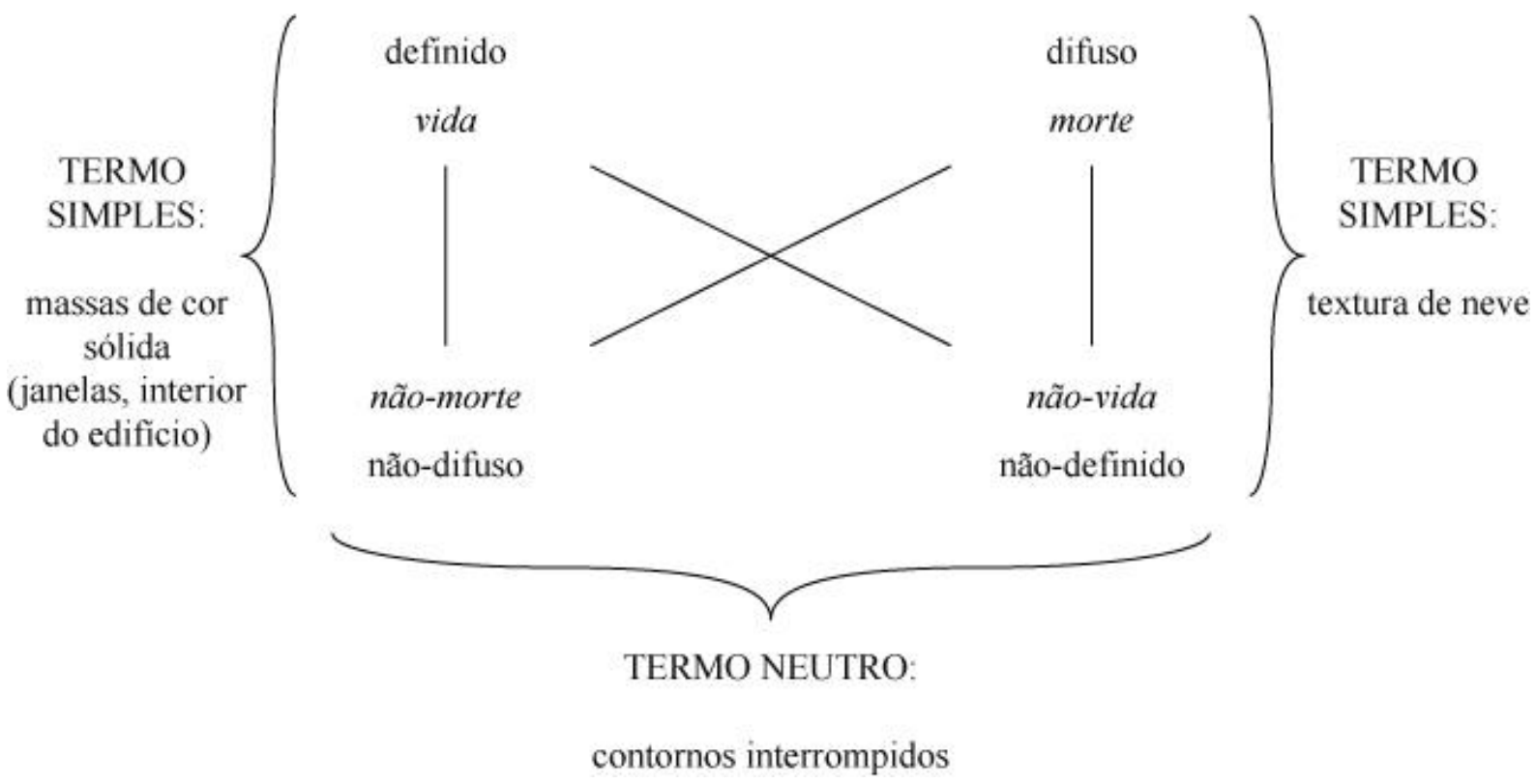

A imagem da rua, misturada à textura da neve, cria um efeito de interrupção das linhas do contorno. Há aí a presença de um não-definido e um não-difuso, que acompanha o sujeito durante a maior parte da história, sendo assim, pertencentes à não-vida e à não-morte.

\subsubsection{A circularidade}

A Figura 19 a seguir mostra como a história se apresenta tridimensionalmente. As formas dos quadros, a posição (de frente ou de costas) da protagonista e até o cenário encontram equivalentes alinhados na frente e no verso na folha:

Figura 19 - Como a frente e o verso da história se relacionam

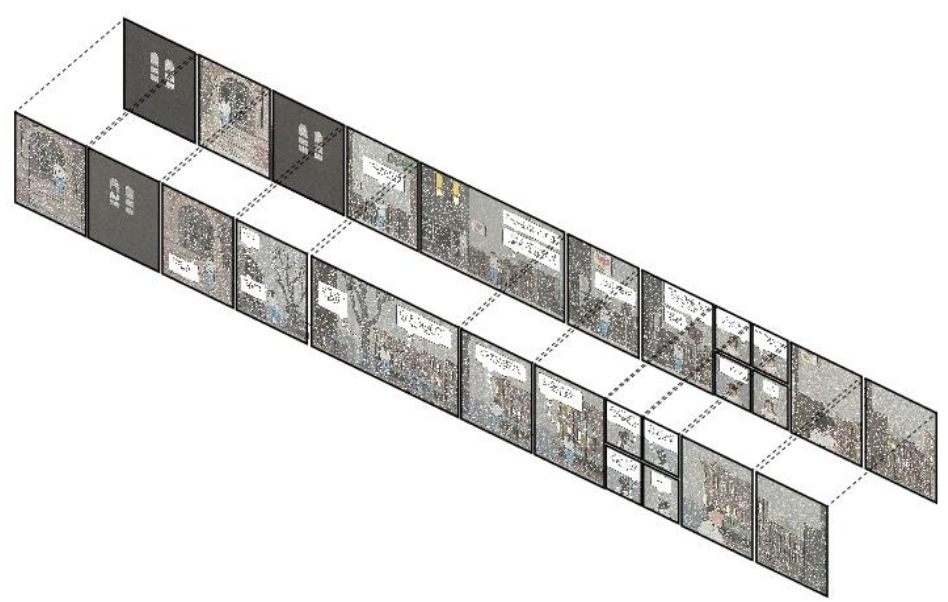

Fonte: WARE (2012). Montagem da autora. 
Isso é importante para se ter em mente durante a leitura, pois esse paralelismo pictórico também se encontra no texto verbal (a descrição das sequências feita anteriormente também demonstra isto), enquanto é possível também identificar equivalentes nos balões de pensamento em ambos os lados.

Figura 20 - nono quadro da Figura 12 e quinto quadro da Figura 11
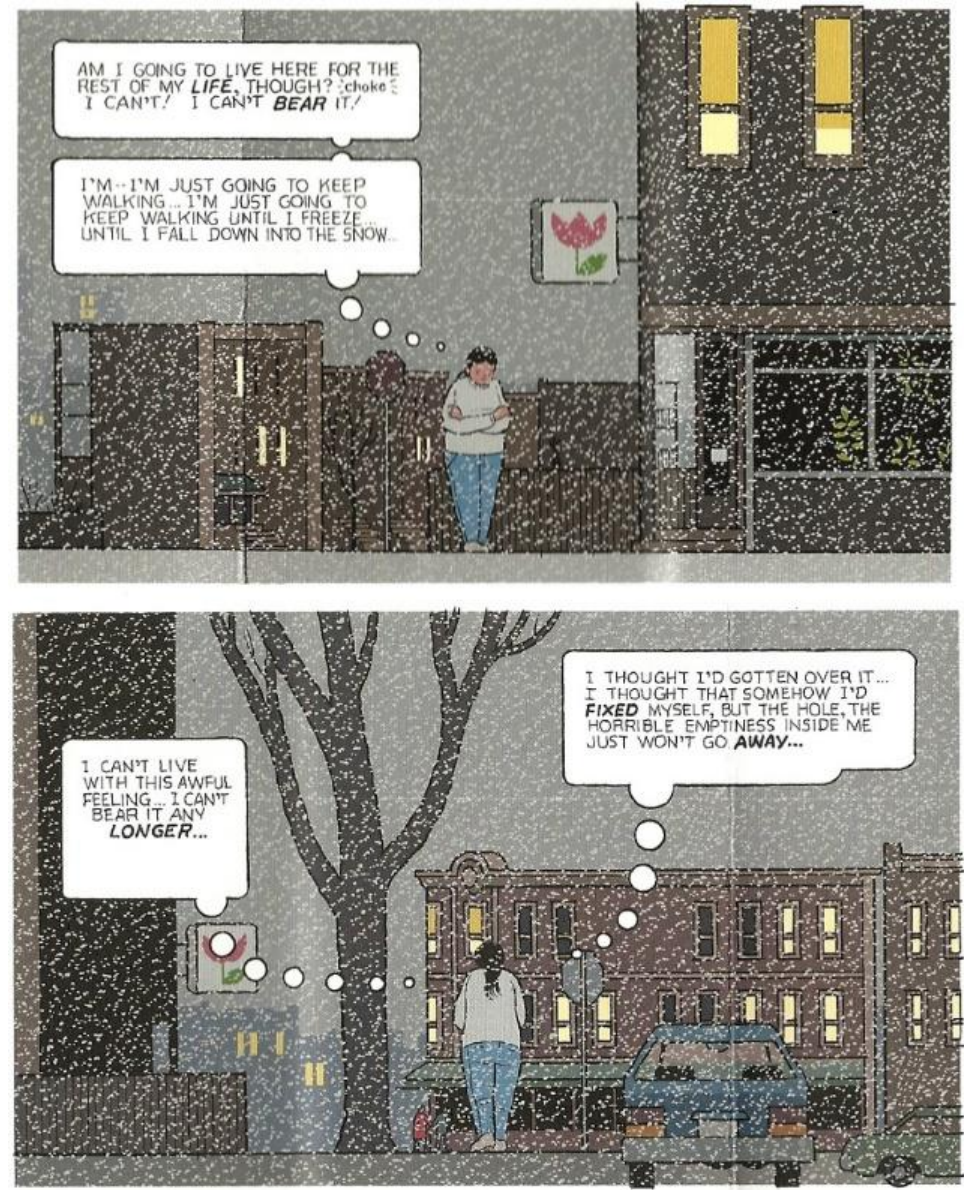

Fonte: WARE (2012). Montagem da autora.

A construção diagramática de Ware cria um paralelismo nas situações e pensamentos e, apesar de colocar a história em uma disposição linear, cria o efeito de tridimensionalidade do espaço. Há repetição de elementos dos textos, como em "deixe que neve... Deixe que me enterre, eu não ligo...” de um lado, e em "isso vai mostrar para eles... Isso vai mostrar para todo mundo...” (ao considerar novamente a morte), de outro. A reiteração desses elementos reforça os pensamentos do sujeito, assim como a paixão da frustração e da angústia presente em toda a história. 
A diagramação também mostra como há a equivalência nos tamanhos dos quadros e enquadramentos, assim como a ausência de um ponto de partida para a leitura e o fato de que a protagonista nunca entra no seu prédio ou alcança os edifícios adiante. Se forem tomadas as sequências nos dois últimos quadros da Figura 11 e os dois primeiros da Figura 12, o que se observa é a mesma cena, com o sujeito protagonista olhando para trás, localizado exatamente no mesmo ponto no espaço e com o quadro mostrando a rua pelo seu ponto de vista:

Figura 21
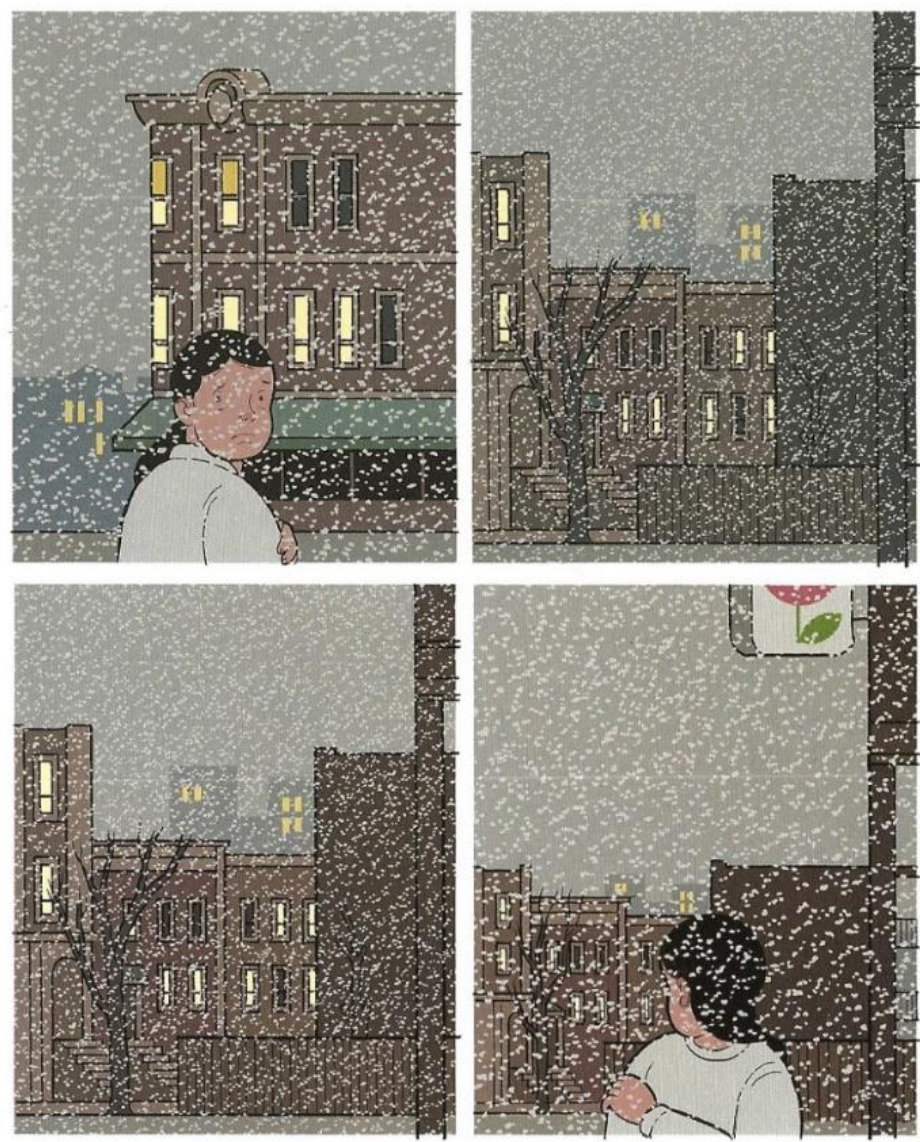

Fonte: WARE (2012)

O leitor não apenas acompanha o percurso da protagonista, mas fica preso com ela em sua indecisão. O sujeito protagonista é virtual durante toda a narrativa, apresentando sempre o querer/dever ser. O percurso passional destaca o ser e as modulações de estado do sujeito. Presa no querer/dever ser, as paixões de angústia e frustração marcam o percurso do sujeito frustrado por não conseguir transformar seu estado de disjunção com os valores desejáveis. Barros (2005, p. 51) coloca que: 
A insatisfação e a decepção conduzem, por sua vez, a outros estados, conforme as mudanças narrativas ocorridas: ou se volta à situação inicial de confiança e satisfação, ou se passa, pelo recrudescimento do sentimento de falta ou de perda, às situações de aflição e de insegurança. A insegurança e a aflição são paixões tensas, resultantes da certeza do sujeito de que não conseguirá os valores almejados e de que o sujeito em quem depositou confiança não era dela merecedor.

A leitura em ambos os lados não oferece uma saída, apenas a possibilidade de retomar os percursos. Cria-se, então, um efeito de leitura circular. A história mostra a angústia de alguém que busca escapar de uma vida indesejável, mas é incapaz de se comprometer com uma decisão (a vida, a morte, a identidade ou a alteridade). Ao longo da narrativa são apresentadas diferentes justificativas para essa situação, como a necessidade de um parceiro (para que seja possível ter uma família) e o questionamento à ideia de como é antiquado querer ter uma família (ou seja, como o desejo não parte necessariamente da protagonista, mas dos valores normativos de uma sociedade conservadora). Mesmo o flerte com o suicídio se mostra como apenas possibilidade, uma vez que não há convicção para escolher a morte (“Deixe que neve...”; grifo nosso).

Em sua construção da história circular, Ware torna possível a manipulação da tira pelo leitor como parte do processo de interpretação. O leitor é, portanto, espectador e colaborador da história: não apenas ele acompanha o desenrolar dos eventos, mas é também aquele que une os fragmentos narrativos, dando-lhes coerência (em seu processo de conclusão). A leitura convencional de quadrinhos é normalmente apresentada em uma estrutura que indica o começo, o meio e o fim da narrativa. No caso deste quadrinho de Building Stories, a angústia, a frustração, a indecisão e a sensação de "prisão" em uma situação inescapável são apresentados pelas falas do sujeito protagonista, mas reforçados pela composição gráfica do quadrinho que, sem determinar seu ponto de partida ou sua conclusão, cria o efeito de uma história que sempre retorna, dando ao leitor a chance de, assim como o sujeito, vivenciar "eternamente" o seu sofrimento. $\mathrm{O}$ efeito de sentido criado é o de suspensão do tempo. $\mathrm{O}$ espaço não muda, a narrativa não apresenta progressão e o retorno ao "início" repete-se indefinidamente. A regularidade do tamanho dos quadros na maior parte da história contribui na percepção de um tempo regular, imutável e de ritmo desacelerado e constante.

A proposta de leitura alternativa, com a circularidade, além de "prender" o leitor na narrativa apresenta uma construção que se relaciona com a própria experiência da leitura: o leitor é aquele com o poder de começar, terminar ou continuar a história quando quiser. $\mathrm{Na}$ 
narrativa gráfica analisada, a protagonista se mostra incapaz de escolher como prosseguir. Ela se vê à mercê de pressões sociais (que lhe impõem papéis) e da interferência de outros sujeitos. A construção verbal e plástica da narrativa não traz uma indicação clara de como libertar-se da história, mas o leitor fica com a responsabilidade e o poder de perpetuar o ciclo ou interrompêlo, seja continuando indefinidamente a leitura da mesma história, ou buscando os outros quadrinhos na caixa e dando continuidade à história da protagonista.

\subsection{Segunda análise: a disposição diagramática da narrativa}

Pietroforte (2014, p. 92) coloca que "Na análise do plano de expressão das histórias em quadrinhos o que se pretende determinar são os processos que organizam a composição plástica do texto que, ao contrário de incidirem sobre um único quadrinho, incidem sobre a totalidade da história". A partir disso, considera-se a importância da organização diagramática na narrativa. As transformações quadro a quadro, cena a cena, são importantes, mas tão importante quanto é considerar, também, a disposição desses elementos gráfico-narrativos no espaço da página como um todo.

O semiólogo Daniele Barbieri (2017, p.129) explora a questão do planejamento gráfico da história em quadrinhos, ressaltando que "dimensão e posição dos distintos elementos são, entre outros, recursos com que se joga". Ou seja, a organização dos elementos gráficos e narrativos sobre o papel visa a criar efeitos de clareza, harmonia, dissonância, aceleração, lentidão, de acordo com o que se pretende expressar na página. Determinadas organizações de elementos gráficos, conduzem, portanto, a determinadas orientações e efeitos de leitura. 
Figura 22
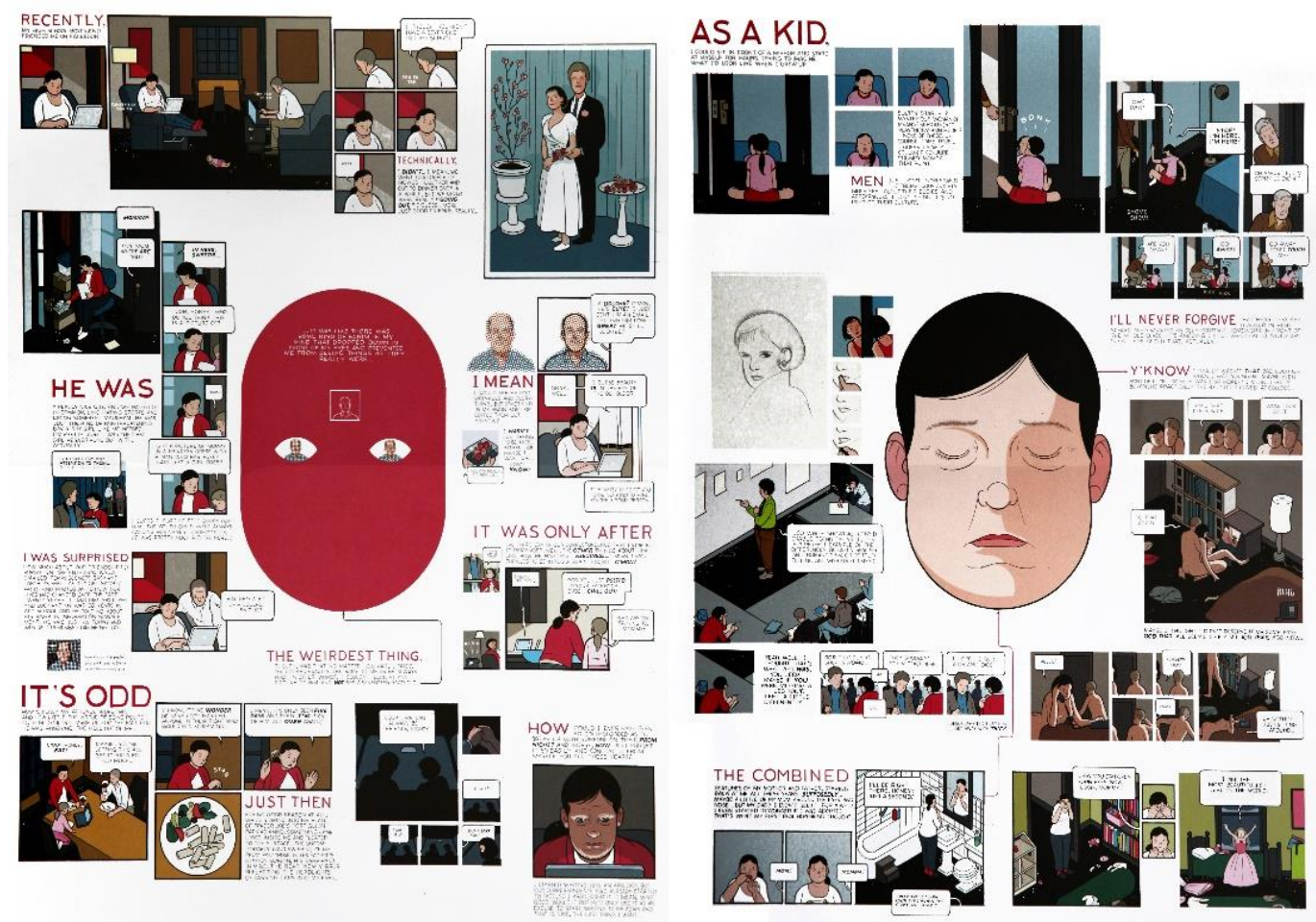

Fonte: WARE (2012)

A análise se debruçará sobre duas histórias (Figura 22), que se apresentam à primeira vista como distintas, mas são complementares uma à outra. A dupla de narrativas está disposta em uma folha de grandes dimensões $(33 \mathrm{~cm}$ por $45,7 \mathrm{~cm}$ ), que se assemelha a um pôster. Novamente, não há indicação por qual lado começar a leitura ou qual história ler primeiro. A escolha de ordem pelo leitor é capaz de influenciar determinados pontos de vista sobre os personagens, mas não afeta a compreensão da proposta central às duas narrativas.

A leitura de quadrinhos pressupõe interconectividade: o quadro "presente" liga-se àqueles imediatamente próximos (seu "passado" e "futuro"). A organização da página nas histórias a seguir oferece mais um plano de leitura: a orientação dos quadros faz o olhar acompanhar não apenas a ordem convencional do quadrinho ocidental (esquerda para direita e de cima para baixo), como também (i) cria efeitos de paralelismo com a narrativa no seu verso; (ii) apresenta sequências digressivas que oferecem outras possibilidades de leitura da mesma história; (iii) possuem figuras centrais em destaque, em torno das quais se organiza a disposição dos quadros, levando a uma consideração da página como um todo e (iv) criam uma relação de dualidade entre seus elementos centrais, ligando os temas abordados por cada narrativa. 


\subsubsection{Analisando um lado}

Figura 23

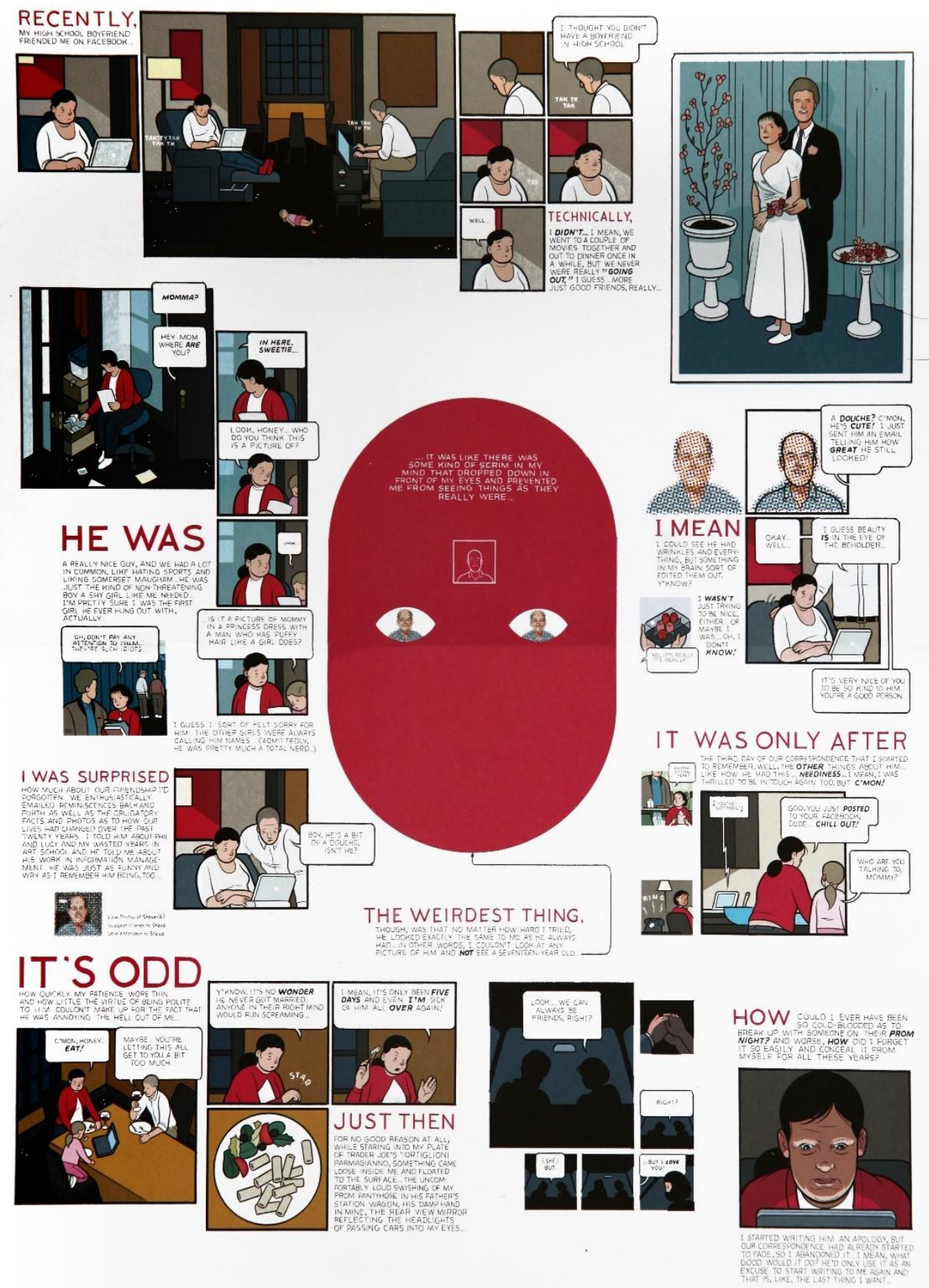

Fonte: WARE (2012).

A narrativa apresenta uma história narrada pela protagonista (a mesma da história anterior), que é contatada na rede social Facebook pelo seu antigo colega de escola, Steve. Ela começa chamando-o de "namorado do colégio", no que é questionada pelo seu marido: "eu achei que você não tinha um namorado no colégio". Isso a leva para uma reconsideração do 
papel desse homem no seu passado e à correção de que eram "bons amigos". A narração continua, trazendo outras informações sobre a identidade do homem, como o que ele e ela tinham em comum, o seu senso de humor e como a personalidade "não-ameaçadora" dele complementava a timidez dela, assim como a amizade parecia ter como base, também, um sentimento de "pena" dela por ele. A reflexão da protagonista traz a constatação de que a amizade dos dois estava há muito esquecida e os dois começam a se corresponder, tentando retomar o contato interrompido há vinte anos. O contato reestabelecido entre os dois cria uma imagem positiva dele para ela, apesar do julgamento externo (de sua filha e de seu marido) ser negativo, algo que ela contesta. No terceiro dia de correspondência, no entanto, outras memórias sobre esse amigo antigo voltam à tona, memórias essas negativas. Em pouco tempo, ela se sente saturada e incapaz de manter o contato com ele. Essa realização traz a lembrança do motivo para o fim da amizade durante a adolescência: no passado, ele estava apaixonado e ela, por sua vez, cortou seu vínculo com ele. No último quadro, apesar da constatação de sua frieza horrorizar a protagonista e ela mostrar uma primeira intenção de se desculpar, sua escolha é manter distância dele.

A história trata das percepções que se tem sobre o outro e como essa identidade é construída, seja pela memória ou pela experiência. A protagonista julga o seu antigo amigo, buscando a verdade sobre quem ele é. É possível perceber uma oposição, portanto, entre a identidade e alteridade:

identidade

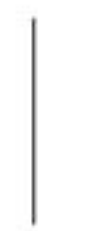

não-alteridade alteridade

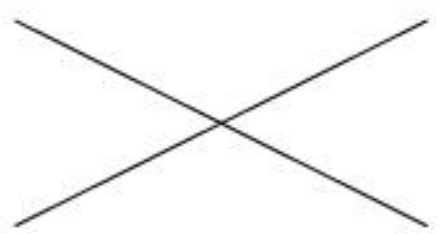

não-identidade

A narrativa apresenta a protagonista incapaz de identificar de maneira precisa seu amigo, seja pela memória, seja pelo conhecimento presente. A busca pela construção dessa identidade começa pela recuperação das lembranças que ela tem dele, com fotos antigas e reflexões sobre a sua adolescência. Isso cria uma imagem positiva dele, que é desfeita quando outras memórias, estas desagradáveis, se juntam a percepções presentes sobre Steve, negando 
a alteridade. A conclusão da história afirma a identidade, com a protagonista criando uma imagem negativa de Steve e de si mesma. A história faz, portanto, o percurso:

$$
\text { alteridade } \rightarrow \text { não-alteridade } \rightarrow \text { identidade }
$$

Os primeiros quadros mostram a protagonista em dúvida sobre o papel do seu antigo amigo na sua vida. A princípio, ela o chama de namorado, mas o questionamento de seu marido a faz repensar quem era aquele rapaz. Gradualmente ela diminui a natureza do vínculo entre os dois, dizendo "[saímos] para jantar de vez em quando, mas nunca "saímos" juntos, eu acho...", para depois classificar a relação como a de "bons amigos". Ela se mostra incapaz de posicionálo nas suas memórias. A imagem do amigo é abstrata e indefinida na mente da protagonista que, como ela mesma observa ao longo da história, esqueceu grande parte da sua amizade com ele. Logo, o amigo (Steve) não possui uma identidade de fato definida pela consciência presente, sendo primeiramente ligada a resquícios de memória, ficando, assim, no campo da alteridade.

Figura 24

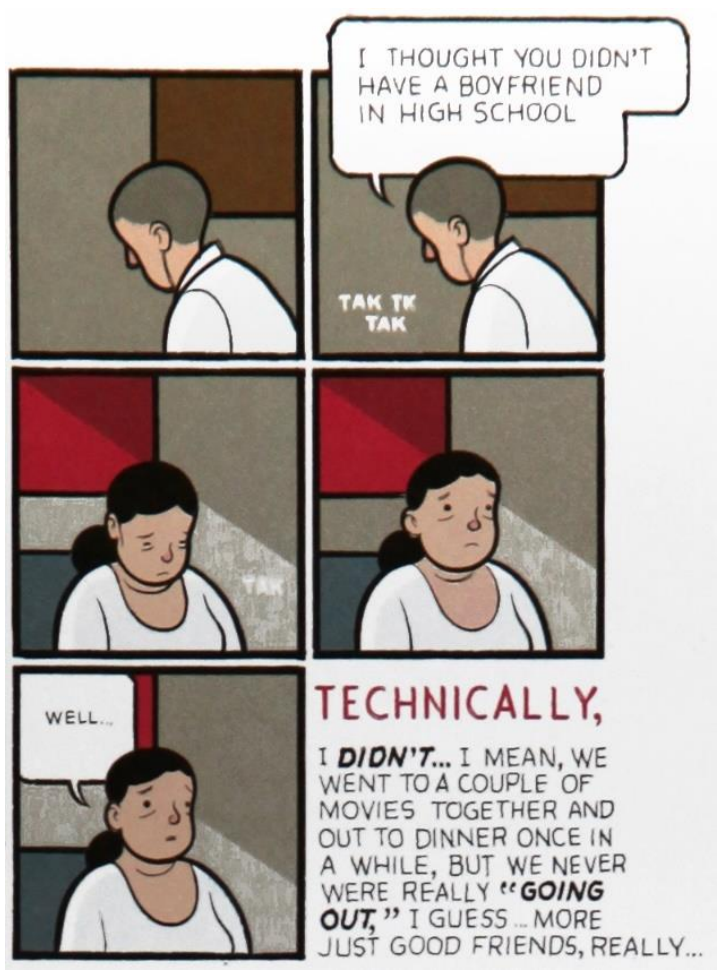

Fonte: WARE (2012)

\section{Tradução nossa:}

"Eu achava que você não tinha um namorado no colégio."

"Bem..." 
"Tecnicamente eu não tinha... Quer dizer, nós saímos para ver alguns filmes e para jantar de vez em quando, mas nunca "saímos" juntos, eu acho... Éramos mais bons amigos, mesmo..."

A fotografia da protagonista e seu amigo, no baile de formatura, antecipa as sequências seguintes, nas quais a narração acompanha paralelamente as cenas da protagonista olhando fotos antigas, em sua busca pela reconstrução da identidade de Steve. A ideia que o sujeito protagonista faz de Steve é ainda construída pelas boas lembranças do passado ("um cara legal", "tínhamos muito em comum", "ele era o tipo de rapaz não ameaçador que uma garota tímida como eu precisava"), o que é reforçado pela narração que descreve a retomada entusiasmada de contato entre os dois, com a protagonista considerando que "ele era engraçado e sarcástico como eu lembrava dele, também...". A visão positiva é confrontada por duas pessoas, no entanto: sua filha (ao perguntar "é uma foto da mamãe em um vestido de princesa com um homem de cabelo fofo que nem uma menina?") e pelo seu marido (ao ver a foto de Steve no Facebook, diz “nossa, ele é meio babaca, não?”). As falas de ambos estão próximas da narração que coloca "eu acho que eu sentia pena dele... As outras garotas estavam sempre chamando ele de vários nomes... (Mas eu admito que ele era um completo nerd...)”. O que se observa, portanto, é a ideia de Steve que se pauta pela nostalgia, mas não há uma definição clara de quem ele é, negando a alteridade.

Essa falta de clareza é evidente na imagem central, uma massa de cor sólida vermelha que se parece com uma máscara: a imagem apenas em traços de Steve aparece pequena, deslocada para a parte superior, enquanto no meio se encontram duas formas que se assemelham a olhos, com a imagem reticulada dele repetida. 
Figura 25

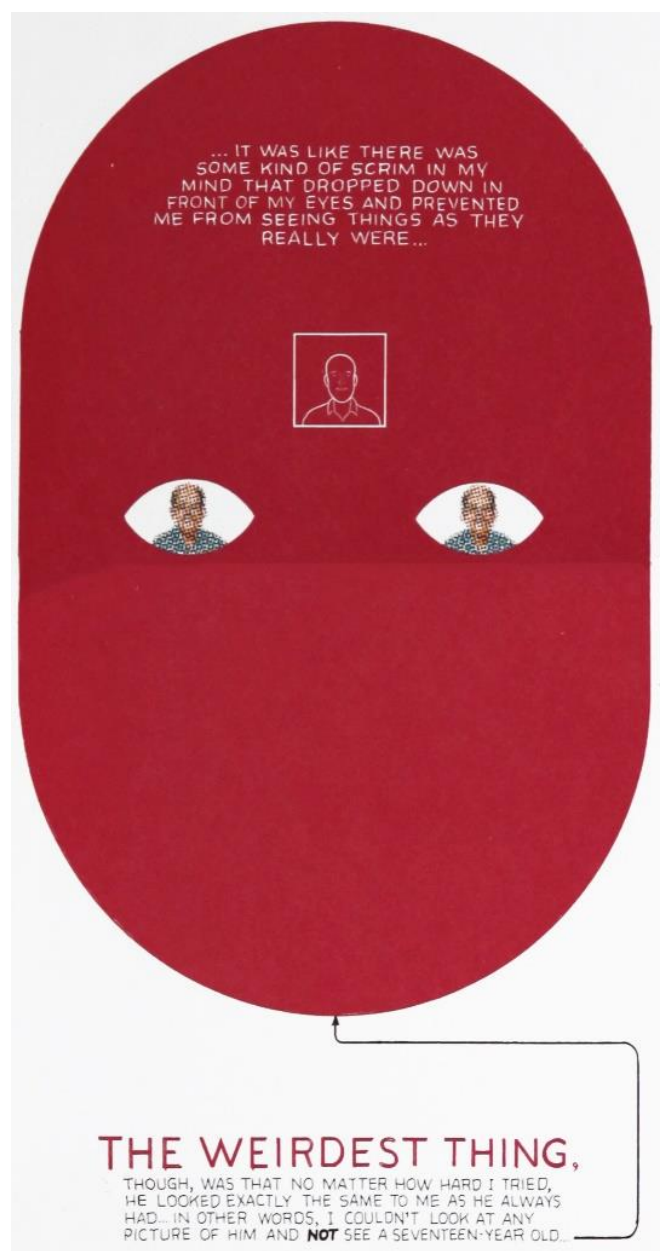

Fonte: WARE (2012)

\section{Tradução nossa:}

"Era como se eu tivesse uma espécie de bloqueio na minha mente que cobria os meus olhos e me impedia de ver as coisas como elas eram..."

"A coisa mais estranha, no entanto, era que, não importava o quanto eu tentasse, ele parecia igual ao que ele sempre foi para mim. Em outras palavras, eu não conseguia olhar nenhuma foto dele e não ver um garoto de dezessete anos."

Ao afirmar que há um "bloqueio" que a faz ver Steve como nada além de um adolescente (a imagem que ela possui mais forte dele, ligada à memória), a protagonista mostra como é incapaz de vê-lo como ele é de fato, apesar das observações feitas tanto pelo seu marido quanto por sua filha, apenas "enxergando" aquilo que foi construído por ela mesma, negando a alteridade.

Ela começa, porém, a confrontar essa imagem construída na sequência seguinte. A princípio há uma hesitação, na negação da pergunta feita pelo seu marido ("um babaca? Ah, vai, ele é uma graça!’), mas ela se questiona sobre sua percepção dele e de si mesma (“eu não 
estava tentando ser gentil, também... Ou talvez eu estava... Oh, eu não sei!”). A hesitação sobre ele também afeta a imagem que ela tem de si mesma. No terceiro dia de correspondência entre os dois, no entanto, a construção positiva que ela possui dele começa a se desfazer: outras lembranças vêm à tona, “como, por exemplo, ele tinha essa... Carência...”, seguindo o percurso que leva à afirmação da identidade.

Figura 26

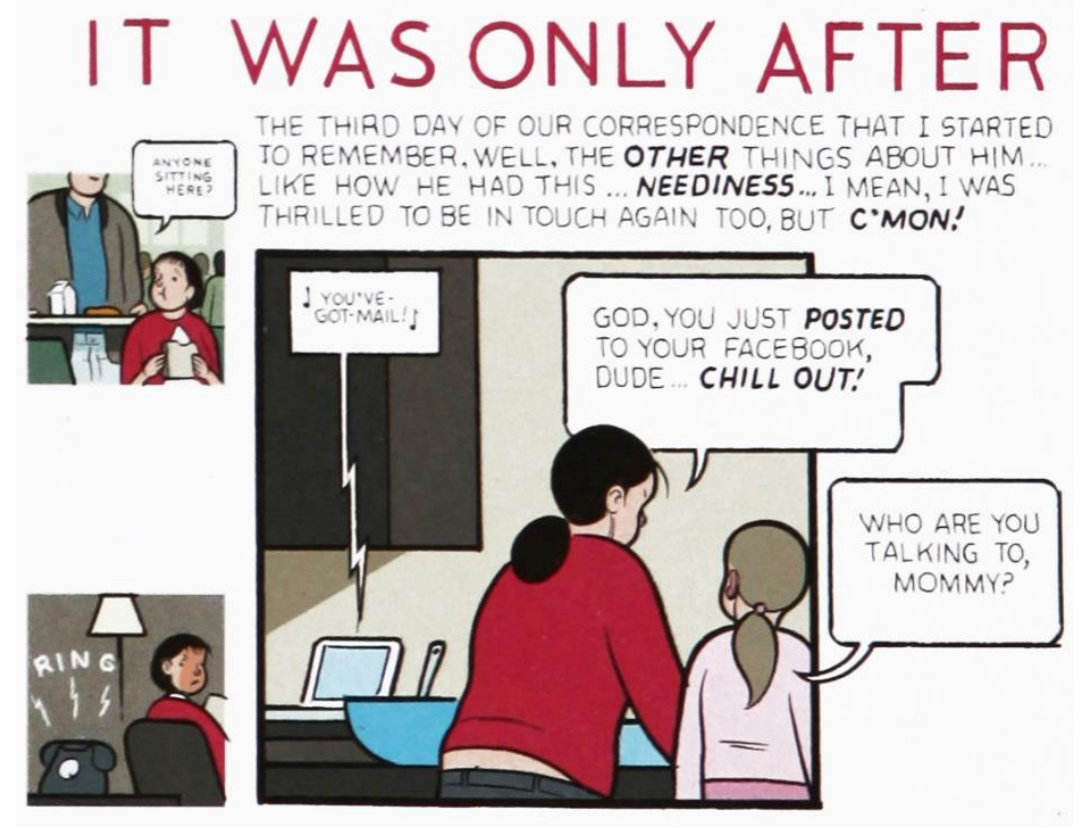

Fonte: WARE (2012)

\section{Tradução nossa:}

"Foi só depois do terceiro dia da nossa correspondência que eu comecei a me lembrar, bem, das outras coisas sobre ele... Como, por exemplo, ele tinha essa... Carência... Quer dizer, eu estava animada por estarmos nos falando de novo também, mas calma lá!"

"VOCÊ TEM UMA NOVA MENSAGEM!"

"Meu Deus, você acabou de postar no seu Facebook, cara... Relaxa!"

"Com quem você está falando, mamãe?”

A sequência final mostra a protagonista profundamente irritada com Steve. A nova percepção sobre ele é completamente negativa (“ele estava me irritando muito", "sabe, não é de se espantar que ele nunca se casou... Qualquer um com juízo sairia correndo...”). Os sete quadros finais da história, no entanto, mostram a protagonista mudando a sua percepção de si mesma. Afirma-se, finalmente, a identidade. 
Figura 27

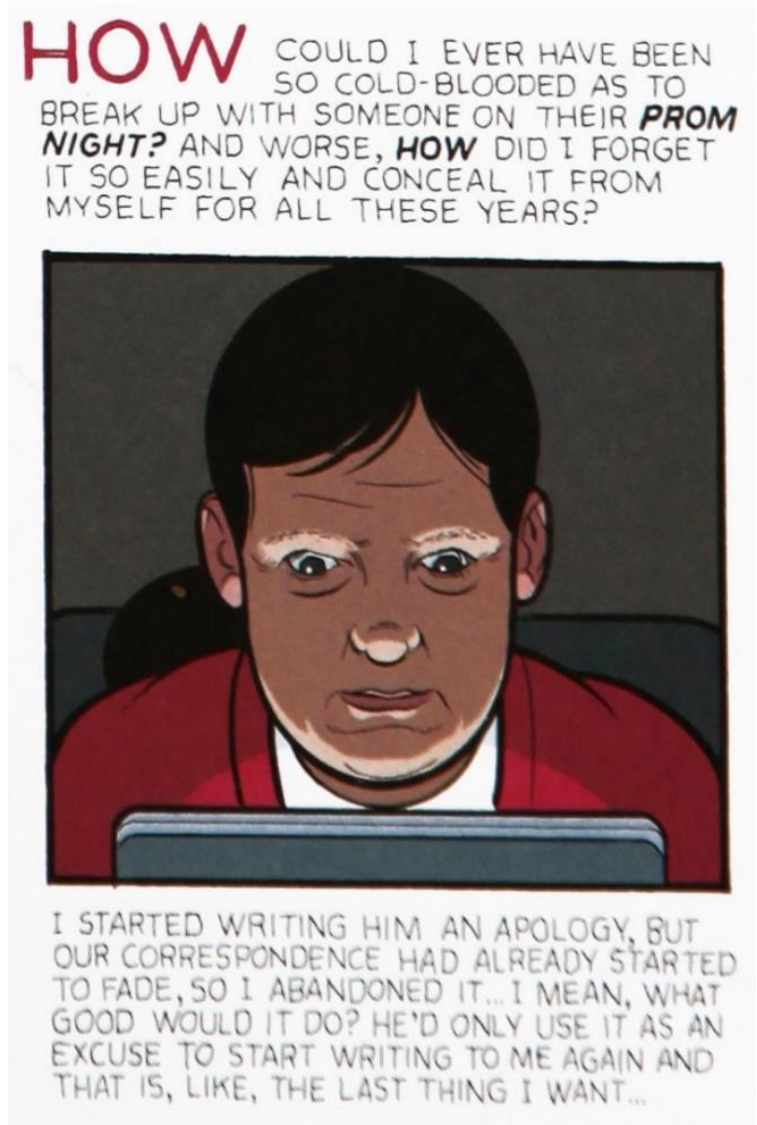

Fonte: WARE (2012)

\section{Tradução nossa:}

"Como eu pude ter o sangue tão frio a ponto de terminar com alguém na sua noite de formatura? E pior, como eu pude esquecer e esconder isso de mim mesma por todos esses anos?"

"Eu comecei a escrever para ele um pedido de desculpas, mas nossa correspondência já tinha começado a diminuir, então eu abandonei. Quer dizer, que bem isso faria? Ele só ia usar como uma desculpa para começar a me escrever de novo e isso era, bem, a última coisa que eu queria..."

Apesar da narrativa não apresentar a manipulação explicitamente, é possível identificar a performance da protagonista. Ao investigar suas memórias, ela executa um fazer-saber, buscando determinar quem é Steve e, nesse exercício, inadvertidamente também descobre mais sobre si mesma. Isso leva a sanções negativas na conclusão da história, mas é válido notar como a sanção está presente durante toda a narrativa. Esse fazer interpretativo verifica se a “identidade" de Steve é e parece ao longo da narrativa. As modalidades veridictórias articulamse no quadrado semiótico: 


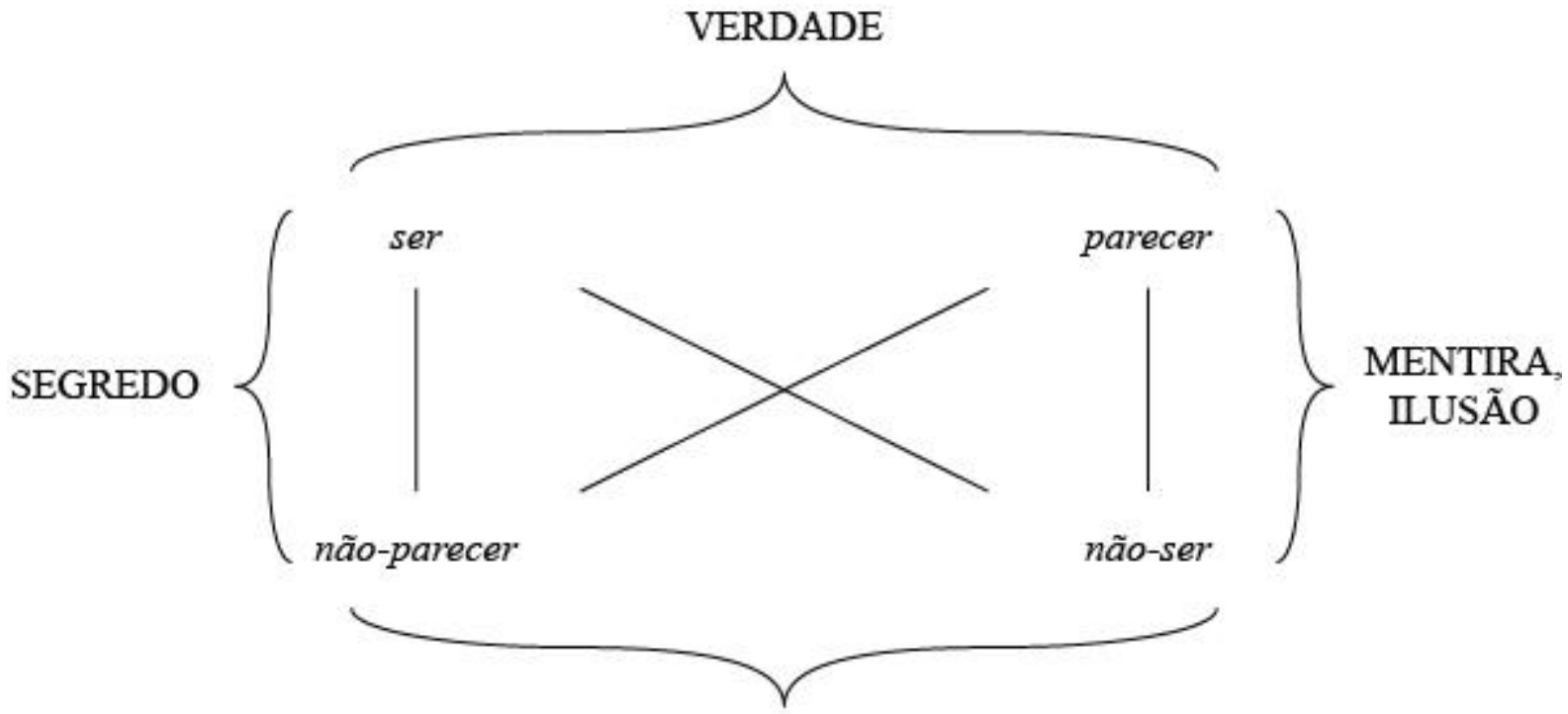

FALSIDADE TOTAL

Greimas (2014, p. 131) afirma que a interpretação é reconhecimento e identificação. O fazer interpretativo lida com os procedimentos de manipulação (argumentação, demonstração, etc.), sendo demasiado variado e cobre campo muito vasto. Por outro lado, ele permite a redução a uma operação de reconhecimento (da verdade):

Ora, ao contrário do conhecimento, o re-conhecimento é uma operação de
comparação entre aquilo que se propõe (= a proposição lógica, no sentido de
"proposição" considerada como sugestão e oferta) e aquilo que já se sabe ou
em que se crê. Sendo uma comparação, o reconhecimento comporta
necessariamente uma identificação, no enunciado apresentado, com a
totalidade ou as frações da "verdade" que já se possui.

A princípio, não é possível identificar quem é Steve. Por meio da reconstrução de sua identidade pelas memórias, a protagonista cria uma "ideia" de quem ele é, a partir da nostalgia da adolescência. Denis Bertrand descreve a nostalgia como "a persistência, na memória do sujeito, de uma conjunção terminada" (2003, p. 360). A amizade entre os dois não mais existe (ela até mesmo diz ter se esquecido de muito dela), mas há a persistência da imagem de uma pessoa que já foi conhecida, que não é necessariamente o "ele" presente, mas sim a projeção de traços do adolescente de dezessete anos sobre o homem adulto que ela vê na tela do computador.

Essa percepção se aproxima do parecer e não-ser, ou seja, da ilusão, o que fica mais claro quando o marido da protagonista confronta essa noção positiva com o seu julgamento negativo. Ela não apenas admite que é incapaz de enxergá-lo como alguém que não seja um adolescente, como também rejeita a afirmação do marido. É apenas no final da história que a 
imagem do presente se torna negativa, unida a outras memórias, também negativas. A nova identidade construída pela protagonista é formada a partir dessas novas percepções, mas a revelação da história é a conclusão que o sujeito protagonista tira sobre si, ao lembrar-se de quando cortou o seu vínculo com Steve na formatura. Ela se percebe não como uma pessoa “piedosa", "virtuosa" ou "gentil” (não é e parece), mas sim como alguém egoísta e de "sangue frio", capaz de ocultar essa verdade de si mesma durante muito tempo (é e não parece). Apesar de tomar conta desse seu traço de identidade, no entanto, ela não busca rever sua ideia de Steve ou se redimir com ele de alguma forma, reafirmando o seu egoísmo: “isso era, bem, a última coisa que eu queria" (grifo nosso).

É necessário explorar o nível discursivo. A história permite identificar na narração o uso da debreagem interna, com a alternância entre a narração em primeira pessoa e os diálogos entre os personagens. Na narração, a debreagem enunciativa cria efeito de subjetividade e envolvimento, com a apresentação do ponto de vista da protagonista sobre Steve e sobre si. Nos quadros, no entanto, dá-se a voz aos outros personagens, criando o efeito de realidade. Ao considerar a transformação da relação entre a protagonista e Steve, o uso da debreagem enunciativa actancial coloca em dúvida se a ideia que ela passa a fazer dele condiz com quem ele de fato é, ou se está completamente comprometida pelo ponto de vista da protagonista.

Apesar da narrativa acompanhar a descoberta gradual da protagonista sobre quem é Steve, o último quadro leva a uma releitura de toda a história. Percebe-se que há uma isotopia temática de memória e conhecimento do outro, tomando a definição de isotopia como "a iteratividade, no decorrer de uma cadeia sintagmática, de classemas, que garantem ao discursoenunciado a homogeneidade" (GREIMAS; COURTÉS, 2013, p. 276). O último quadro, portanto, funciona como um desencadeador de isotopias, colocando em crise o conhecimento que a protagonista tem de si mesma, assim como o conhecimento do enunciatário, o leitor, sobre os julgamentos que ela havia feito até então, sobre si e sobre Steve. Ela deixa de parecer uma pessoa de certa maneira frágil e gentil, e se mostra dura e até mesmo cruel.

\subsubsection{As categorias topológica e eidética}

Na história, a transformação da consciência da protagonista sobre quem é Steve está organizada em uma ordem específica na página como um todo: o início da construção da 
memória se dá nos quadros superiores, o confronto entre memória e realidade se dá nos quadros intermediários e a constatação da realidade se dá nos quadros localizados na base da página. Assim, é possível estabelecer a categoria topológica acima vs. abaixo, em que:

\author{
acima - alteridade \\ centro - não-alteridade \\ abaixo - identidade
}

Figura 28
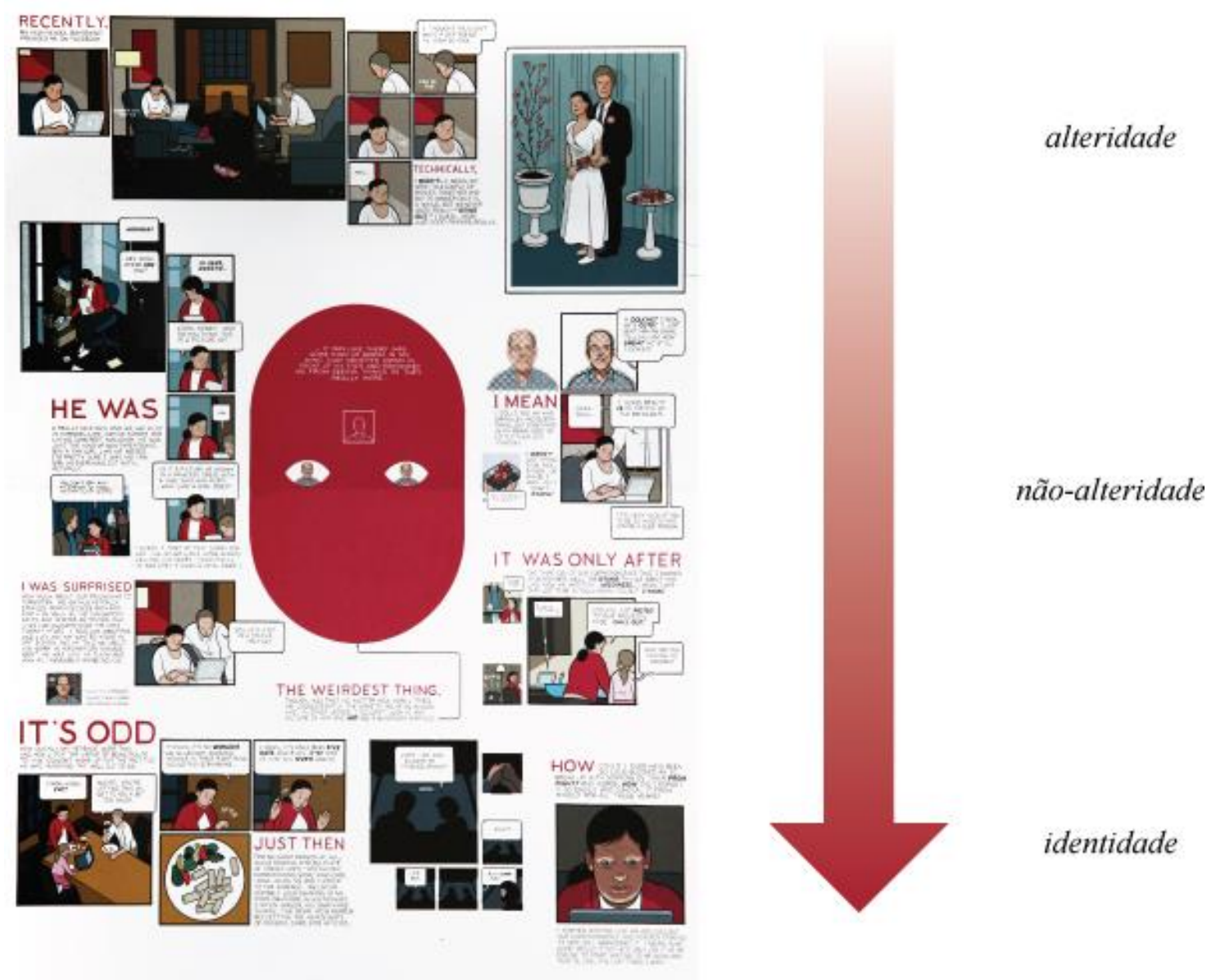

Fonte: WARE (2012). Montagem da autora

O mesmo percurso de cima para baixo se percebe na pequena sequência de quadros que estabelecem um paralelo com a história principal (Figura 30). Neles, é possível acompanhar a transição da percepção da protagonista, com a narração ligando os dois momentos: o passado e aquele mais próximo do presente (“eu não estava tentando ser gentil, também... Ou talvez eu estava... Oh, eu não sei!"). O percurso vertical permite ver a transição da relação entre os dois 
personagens, culminando na interrupção de qualquer possibilidade de envolvimento amoroso pela protagonista, com Steve declarando seu amor.

Figura 29
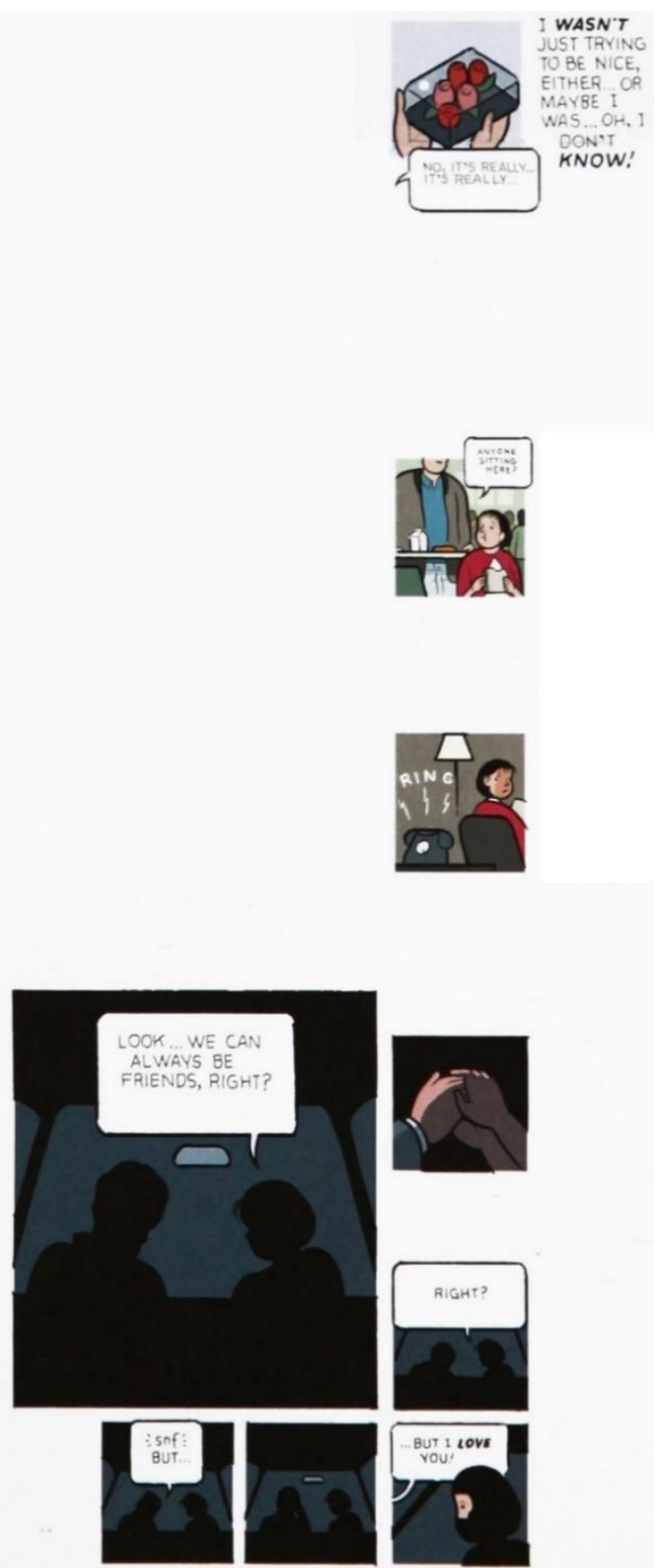

Fonte: WARE (2012)

O centro da página apresenta uma imagem isolada, livre das margens de um quadro, que se assemelha a uma máscara (Figura 25). Nela, onde estariam os olhos, está a imagem reticulada da foto do amigo (presente também do lado direito da página). Acima, a mesma foto aparece apenas em contornos, sem um preenchimento de cor que torne possível "corporificá-lo". Ao 
lado, as duas imagens se repetem: primeiro, a foto reticulada e depois, a mesma foto com o contorno aplicado por cima. Ao relatar suas impressões, a protagonista fala como era incapaz de ver o seu amigo como realmente era e a única imagem que possuía era não a do homem adulto, mas do rapaz adolescente.

Figura 30 - a imagem reticulada e com a sobreposição do contorno

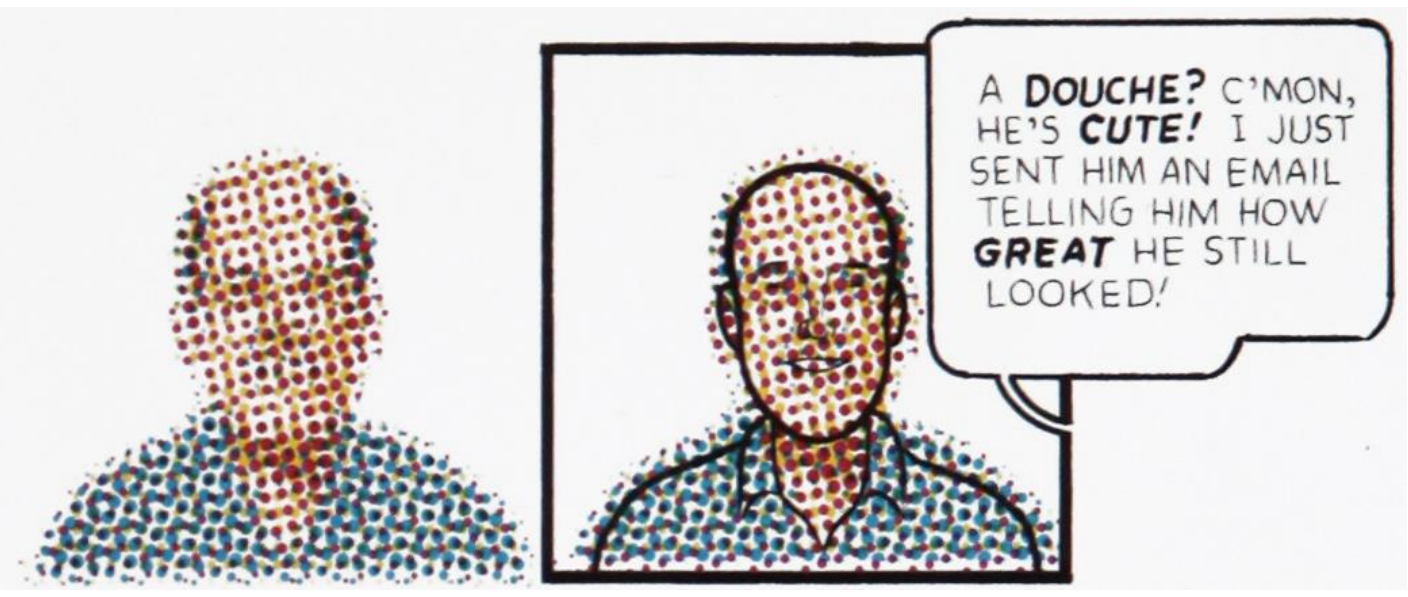

Fonte: WARE (2012)

A imagem com apenas traços também apresenta uma informação sobre o que a protagonista "vê" na imagem de Steve: o desenho dos personagens do quadrinho mostra o que é necessário para criar uma imagem identificável de Steve (como aparece na fotografia). A imagem do sujeito Steve precisaria apresentar o mesmo tipo de contorno e de preenchimento (massa de cor) definido que os demais possuem. A primeira imagem que se tem dele no "presente" é, no entanto, uma figura reticulada, sua foto de perfil da rede social: "Era como se eu tivesse uma espécie de bloqueio na minha mente que cobria os meus olhos e me impedia de ver as coisas como elas eram..." e "A coisa mais estranha, no entanto, era que, não importava o quanto eu tentasse, ele parecia igual ao que ele sempre foi para mim. Em outras palavras, eu não conseguia olhar nenhuma foto dele e não ver um garoto de dezessete anos.". Se for comparada a imagem apenas com traços (Figura 31) e a fotografia dos dois personagens (Figura 32), é possível perceber que não há grandes diferenças entre elas, reafirmando a percepção distorcida da protagonista. 
Figura 31 - visualização mais clara de como os contornos se apresentam.

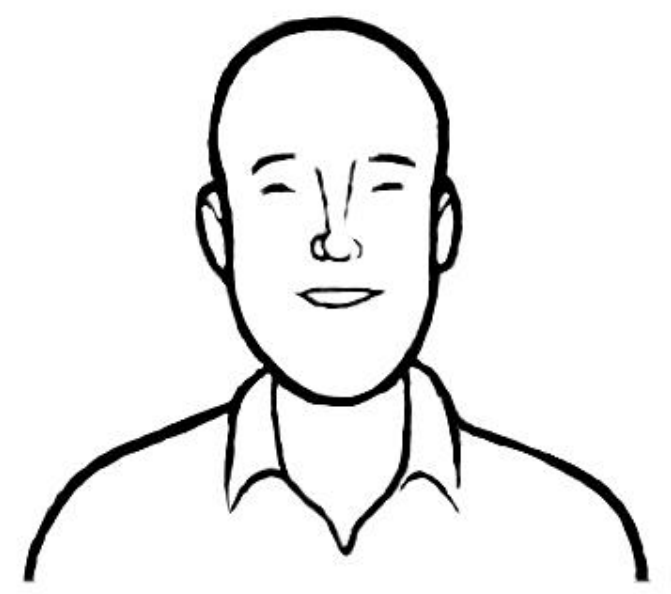

Fonte: WARE (2012). Montagem da autora.

Figura 32

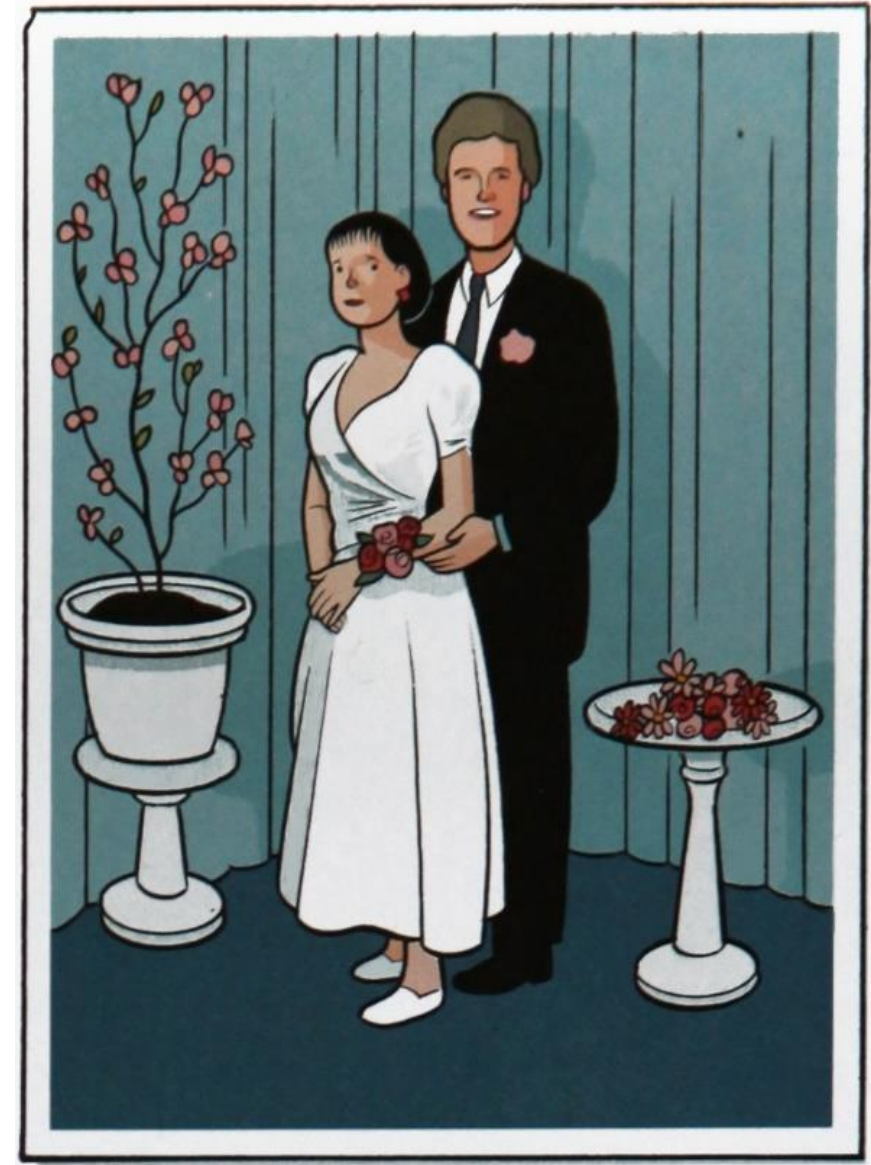

Fonte: WARE (2012)

A imagem que busca se aproximar da "realidade presente" é a figura reticulada, acompanhada das informações de perfil do Facebook de Steve: 
Figura 33

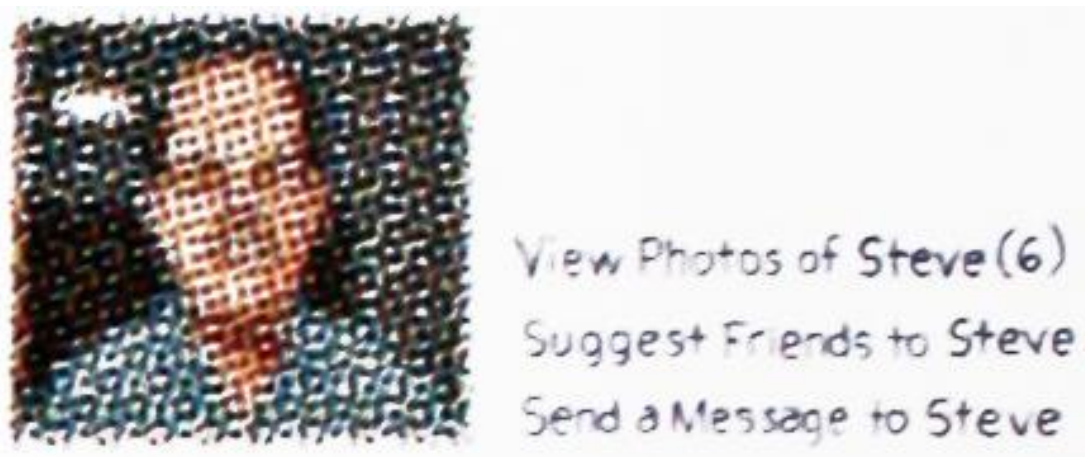

Fonte: WARE (2012)

É interessante observar a imagem reticulada e sua relação com a alteridade. A construção de um "perfil" compreende uma curadoria feita pelo indivíduo dos traços considerados mais interessantes (para ele) a serem compartilhados com seus pares. Isso significa que a percepção do outro e sua apresentação para os demais é mediada por um filtro ideológico, considerando o que Greimas e Courtés (2013, p. 252, 253) colocam sobre ideologia:

4. Uma ideologia se caracteriza então pelo estatuto atualizado dos valores que ela assume: a realização desses valores (isto é, a conjunção do sujeito com o objeto de valor), extingue, ipso facto, a ideologia enquanto tal. Em outros termos, a ideologia é uma busca permanente dos valores, e a estrutura actancial que a informa deve ser considerada como recorrente em todo discurso ideológico.

Três imagens de Steve aparecem no texto: aquela com traços, a imagem reticulada e aquela sobreposta. A imagem reticulada se mostra mais como uma textura do que algo definido (ela mostra o homem que a protagonista não reconhece). A imagem com traços apresenta alguma definição, mas lhe faltam massas de cor que preencham os espaços vazios e lhe deem profundidade. A sobreposição da imagem reticulada e a que só possui traços tenta se aproximar de algo mais concreto, mas ela é confusa, assim como a visão sobre Steve é imprecisa. A partir disso é possível perceber uma oposição na categoria eidética difuso vs. definido, em que: 


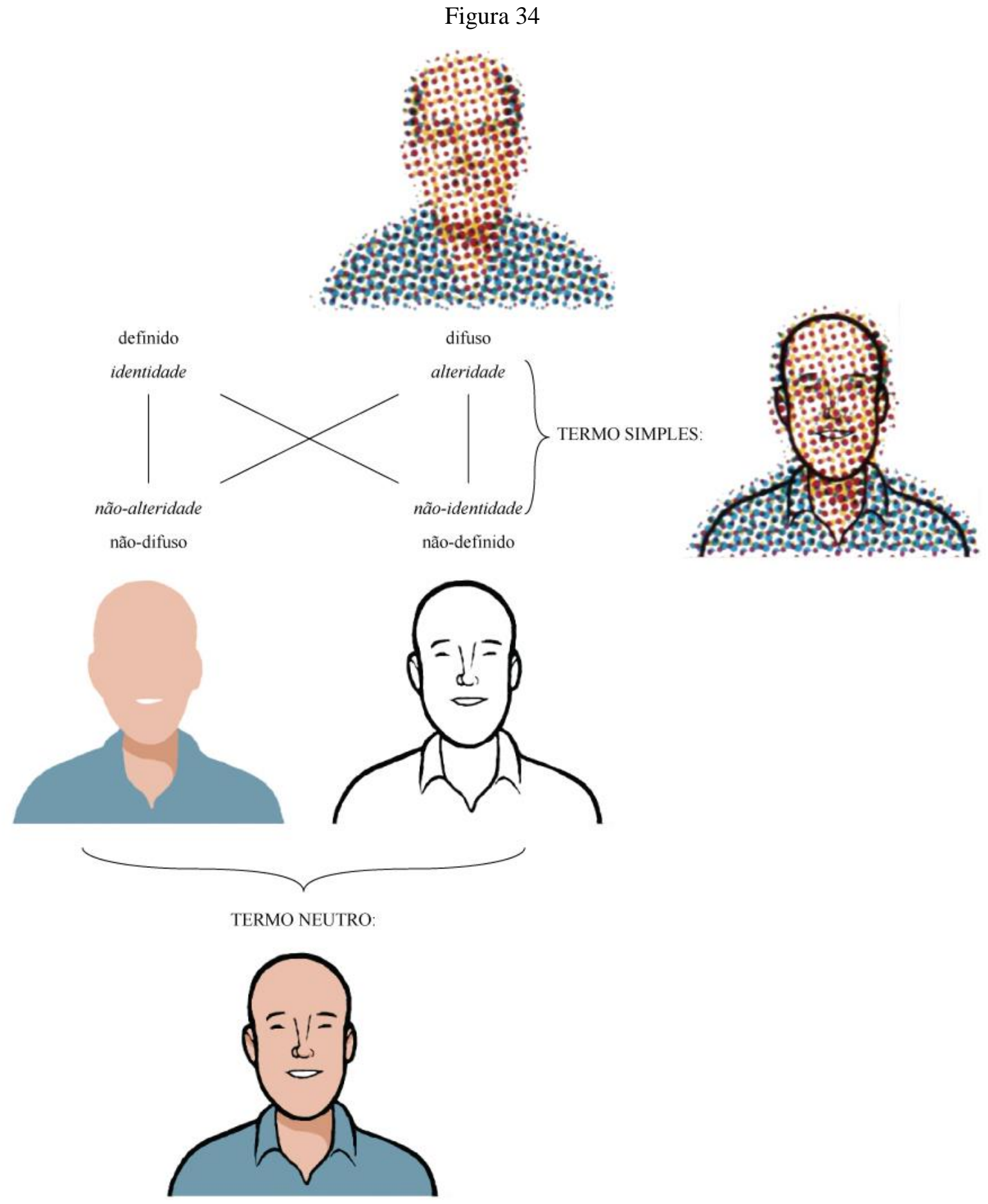

Fonte: Montagem da autora.

O quadrado semiótico apresenta uma imagem não presente no texto: a massa de cores sólidas que preencheriam os traços. Enquanto negação do que é difuso, a negação da textura de retícula seria a massa definida de cor. Falta, no entanto, a imagem relacionada à identidade. Isso levanta questionamentos sobre o que o sujeito Steve é e o que ele aparenta ser. Acompanhando a história pelo ponto de vista da protagonista, o leitor o vê pelos "olhos" dela 
durante a maior parte da narrativa. Nunca se tem uma noção clara, tampouco, de como a filha e o marido o enxergam, para além dos seus julgamentos negativos. Mesmo quando sua visão sobre Steve muda, nunca é mostrada a sua imagem transformada. O que se transforma, porém, é a imagem da própria protagonista (Figura 35).

Figura 35

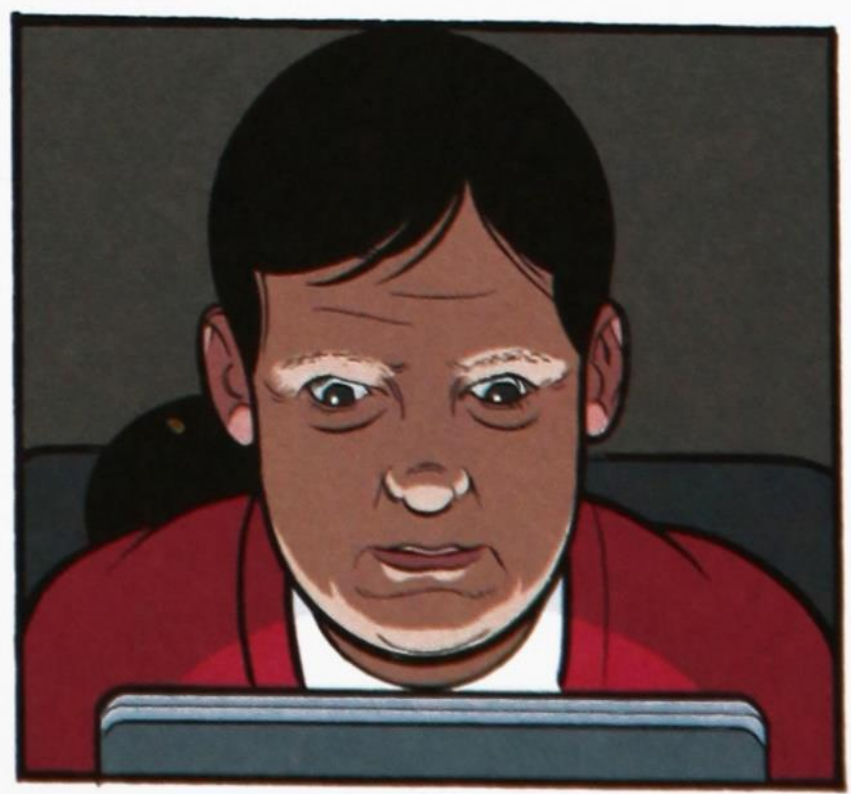

Fonte: WARE (2012)

Seus traços não são mais cartunescos e delicados como em quase toda a história, mas sim realistas ${ }^{13}$, evidenciando os detalhes da sua face (cuja expressão parece mais desagradável com o efeito de sombras do quadro). Isso traz uma pista de como deveria ser a imagem "real" de Steve, ou ao que dela se aproximaria: a visão de um "homem real".

\subsubsection{O outro lado: analisando a segunda história}

\footnotetext{
${ }^{13}$ McCloud (2005, p. 28-38) observa que o cartum possui caráter icônico, sendo possível, com o mínimo de informações plásticas, criar a imagem de um rosto. Ele nota que, quão mais simples é a imagem, mais fácil é para o leitor identificar-se com a figura que vê (e, assim, envolver-se com a história). Uma imagem realista, por outro lado, aponta para a singularização de um indivíduo (que não o leitor, criando um efeito de objetividade). Portanto, o autor coloca que se constroem, pela linguagem dos quadrinhos, efeitos de envolvimento ou afastamento, ou seja, são utilizados mecanismos de debreagens enunciativas e enuncivas por meio da complexidade da imagem.
} 
Figura 36

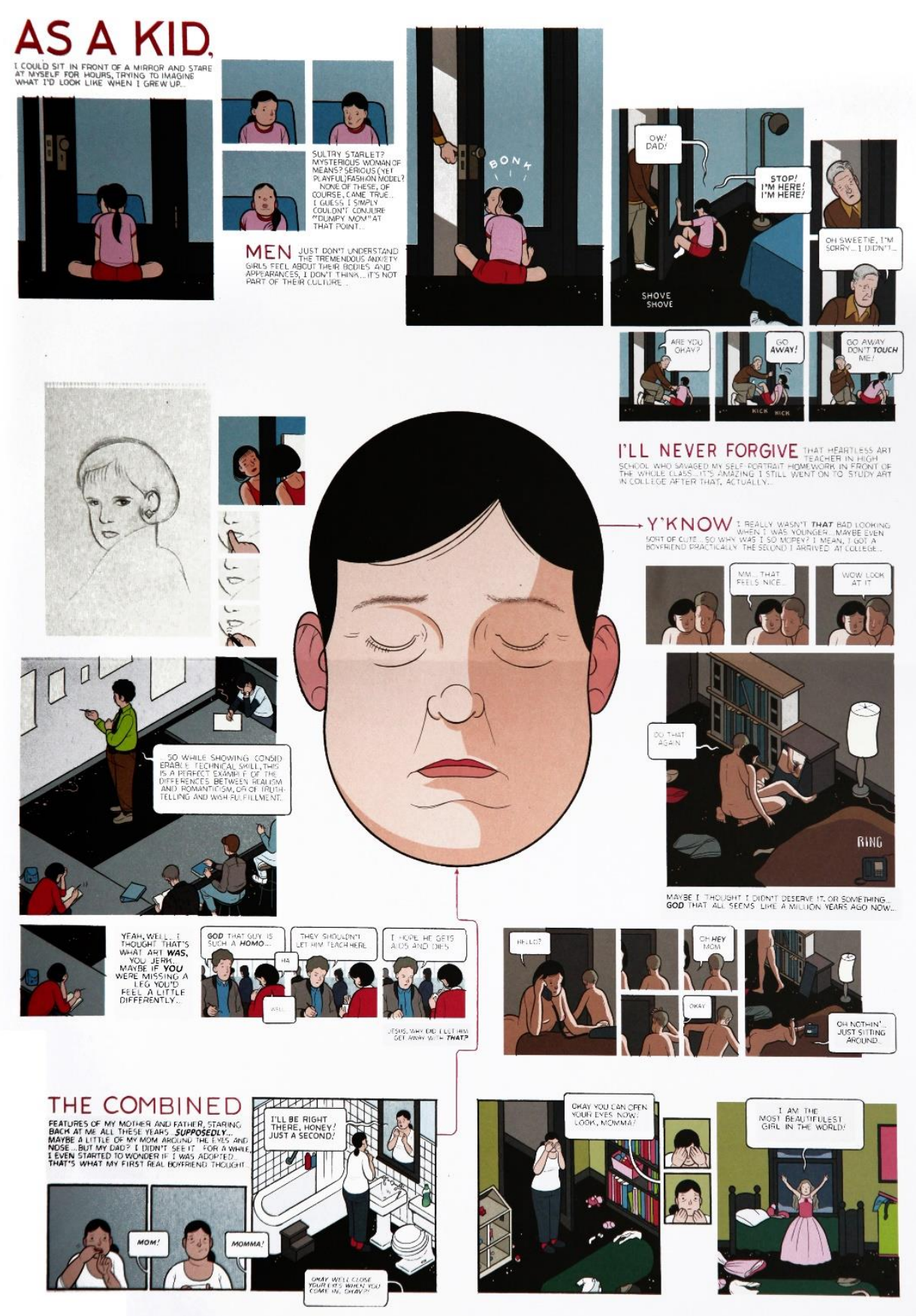

Fonte: WARE (2012).

A história de Ware apresenta a protagonista em diferentes momentos da sua vida. $\mathrm{O}$ período da infância descreve as expectativas que o sujeito tem sobre a mulher que ela se tornaria (“celebridade sensual? Mulher misteriosa e rica? Modelo séria (mas divertida)?”). O primeiro salto no tempo dentro da narrativa a mostra na adolescência, fazendo um autorretrato para a aula de artes. A análise da ilustração pelo professor em sala de aula é traumática para a protagonista, uma vez que ele aprecia a qualidade técnica, mas critica a falta de "sinceridade" 
da representação. O terceiro momento mostra a protagonista durante o período da faculdade, em um momento íntimo com o seu namorado. Nus, eles observam o corpo dela no espelho, enquanto o tocam. A visão sobre si mesma não possui as expectativas da infância, mas sim é mais crua e explícita. A sequência final, então, mostra a protagonista em um momento mais próximo ao presente, já adulta e com uma filha. Ao se observar no espelho, ela percebe quem é a mulher que se tornou, alguém com “os traços combinados da minha mãe e do meu pai”. Sua filha a chama em outro cômodo e, quando a protagonista vai vê-la, é recebida pela frase "sou a garota mais lindíssima do mundo!”.

Tal qual a história anterior, esta narrativa também apresenta a oposição entre alteridade e identidade, sendo uma história sobre a construção da imagem do indivíduo pelas expectativas, desejos e consciência. Realiza-se, portanto, o mesmo percurso alteridade $\rightarrow$ não-alteridade $\rightarrow$ identidade, assim como a relação topológica acima vs. abaixo:

Figura 37

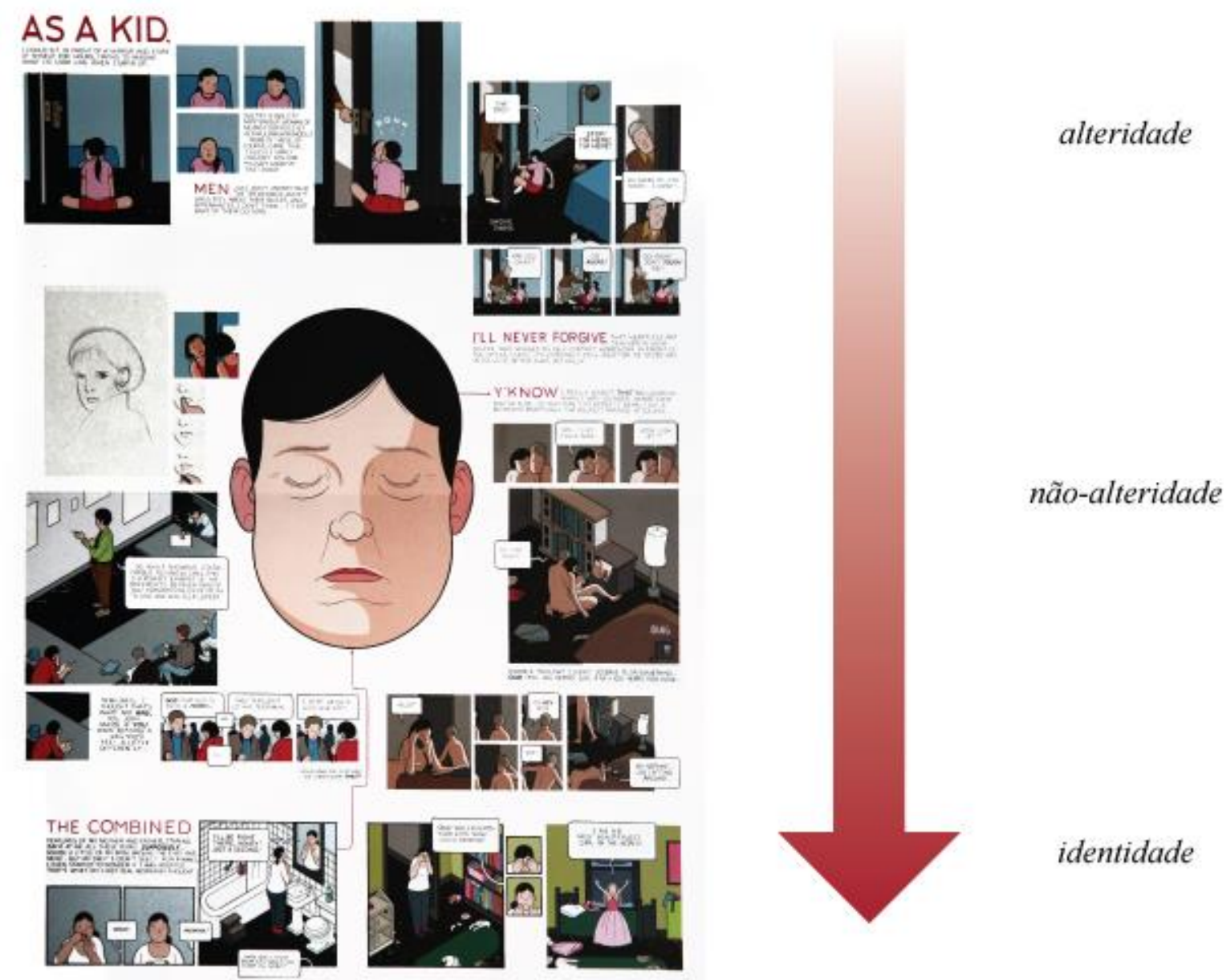

Fonte: WARE (2012). Montagem da autora 
A alteridade é afirmada nos quadros superiores, com a protagonista durante a sua infância, se olhando no espelho e fazendo diferentes expressões faciais como uma forma de antecipar a mulher que se tornaria ("quando criança, eu era capaz de sentar na frente de um espelho e ficar me olhando por horas, tentando imaginar com o que eu me pareceria quando crescesse...”). Assim como ela considera todas as possibilidades, também reflete sobre a pressão sofrida por meninas para atender uma aparência física atraente (segundo os padrões normativos). Quando seu pai sem querer bate a porta nela, a protagonista o expulsa e repele seu toque, como que constrangida ao ser descoberta em um momento tão pessoal.

Figura 38

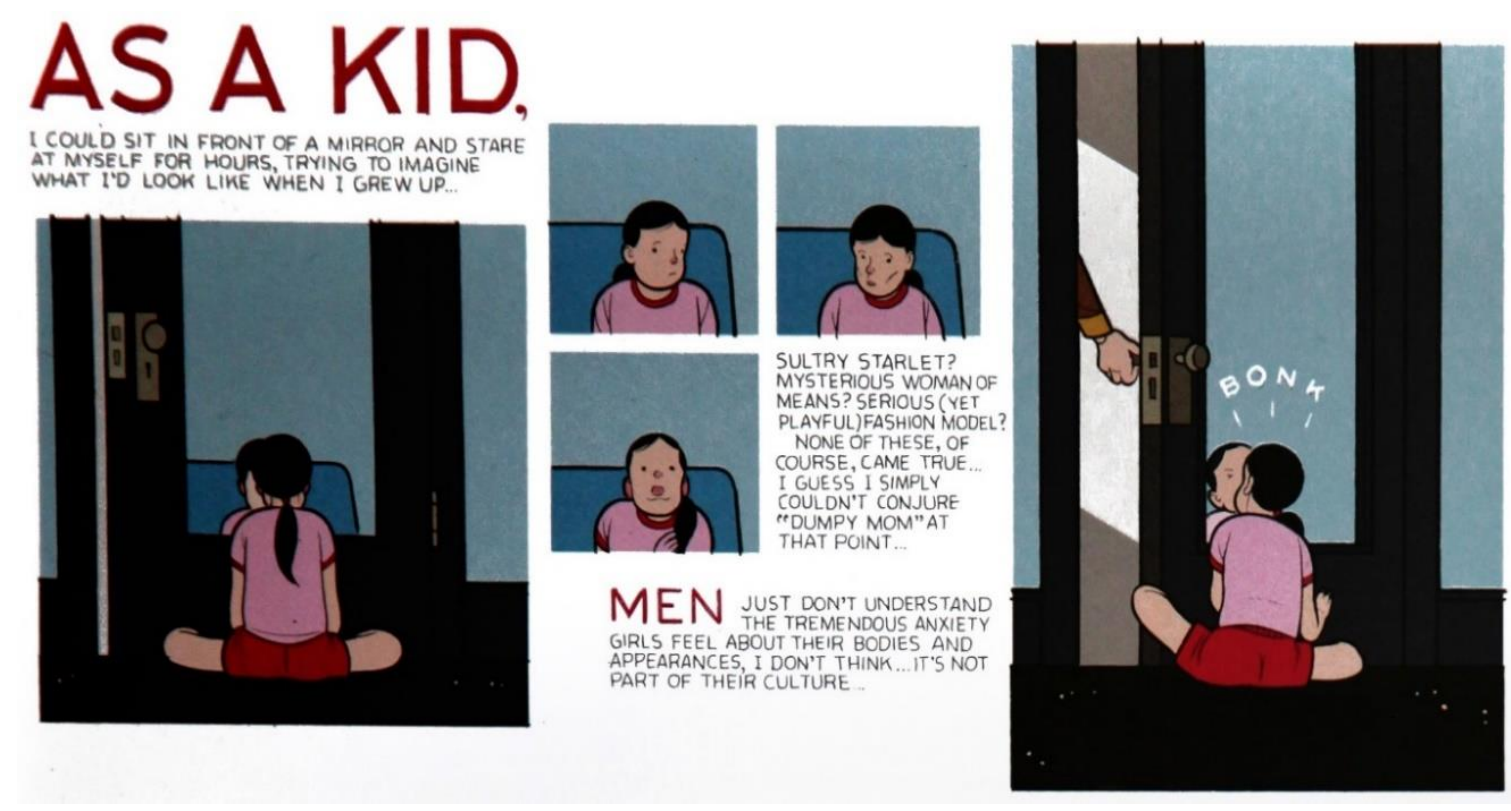

Fonte: WARE (2012)

\section{Tradução nossa:}

"Quando criança, eu era capaz de sentar na frente de um espelho e ficar me olhando por horas, tentando imaginar com o que eu me pareceria quando crescesse..."

"Celebridade sensual? Mulher misteriosa e rica? Modelo séria (mas divertida)? Nenhuma dessas opções se tornou realidade, claro... Eu acho que eu simplesmente não era capaz de conjurar 'mãe atarracada' naquele momento..."

"Homens simplesmente não entendem a tremenda ansiedade que meninas sentem sobre seus corpos e aparências, eu acho... Não é parte da cultura deles..."

A sequência que mostra o sujeito protagonista durante a adolescência apresenta a negação da alteridade ao mostrar o autorretrato. Ela se olha no espelho e faz ajustes no desenho. Ao mostrar para a classe, seu professor diz que "este é um perfeito exemplo entre o realismo e 
o romantismo, ou entre a sinceridade e a realização de desejos....". A fala confronta a visão construída pelo sujeito, passível de distorções por conta de suas expectativas e suas inseguranças, por ser uma jovem que apresenta uma deficiência física ("talvez se você não tivesse uma perna, se sentiria diferente a respeito disso...). O episódio é traumático, fazendo com que a protagonista rejeite a afirmação do professor, chamando-o de "desalmado" e "idiota".

Figura 39

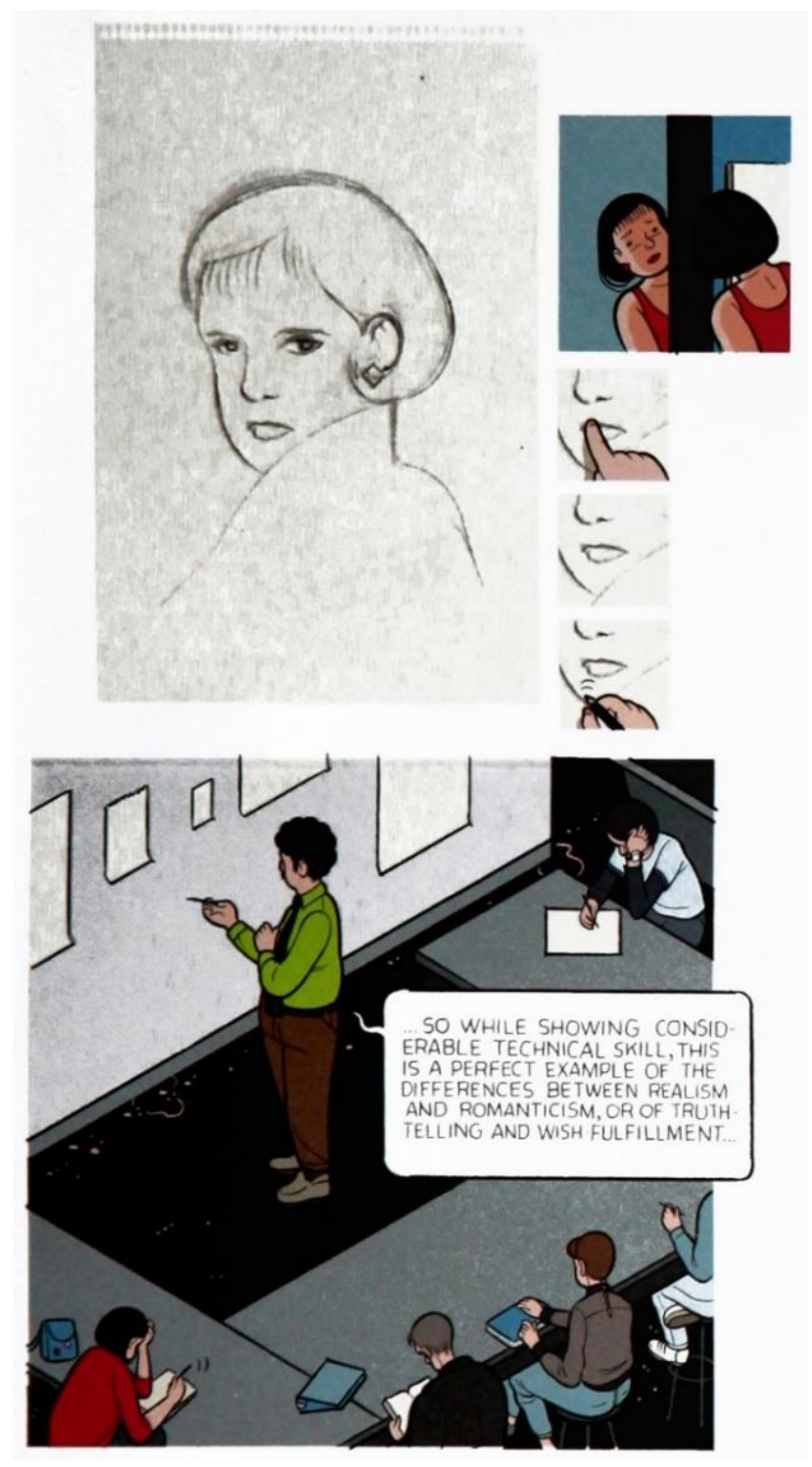

Fonte: WARE (2012)

\section{Tradução:}

“... Então, apesar de mostrar habilidade técnica considerável, este é um perfeito exemplo entre o realismo e o romantismo, ou entre a sinceridade e a realização de desejos..." 
O percurso segue em direção à afirmação da identidade na sequência que mostra o sujeito protagonista durante o início da idade adulta. Sua ponderação fica entre uma visão positiva e negativa de si mesma ("sabe, eu realmente não era tão feia assim quando mais nova... Talvez fosse até bonitinha... Então porque eu era tão cabisbaixa?"). Os quadros mostram a descoberta do corpo e do sexo, uma visão distanciada dos sonhos infantis e das inseguranças da adolescência. Ela não apenas vê o seu corpo, mas também o toca, com o namorado. A narração elabora sobre a melancolia da protagonista, considerando como ela talvez não merecesse o relacionamento que teve, reafirmando seus sentimentos de insegurança.

Figura 40

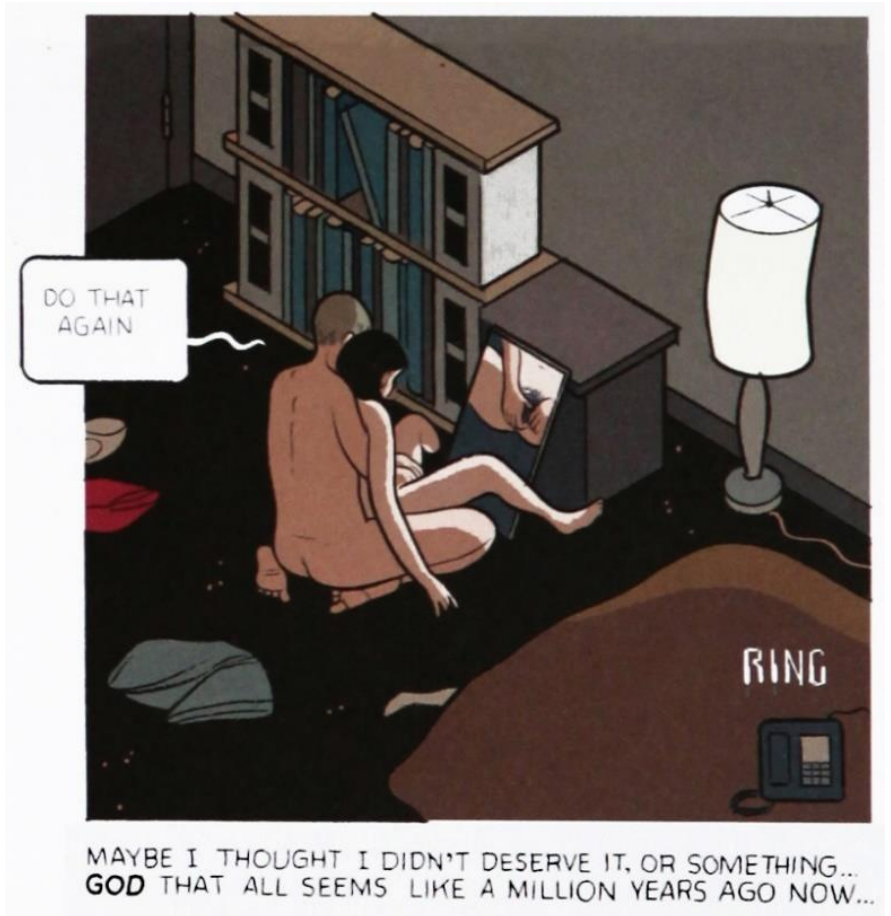

Fonte: WARE (2012)

\section{Tradução:}

"Faz aquilo de novo"

"Talvez eu achasse que eu não merecesse aquilo ou coisa parecida... Deus, tudo parece que faz. milhões de anos..."

A afirmação da identidade aparece nos últimos quadros, na base da página. A protagonista novamente se observa no espelho, percebendo a realidade: "os traços combinados da minha mãe e do meu pai, me encarando de volta depois de todos esses anos...”. Quando sua 
filha a chama, ela cobre seus olhos, mas, ao abri-los, a menina diz "sou a menina mais lindíssima do mundo!". A criança aparenta ter uma percepção mais positiva (e segura) de si do que a protagonista durante sua infância, com uma noção de sua identidade que parece desligada de dúvidas e receios.

Figura 41
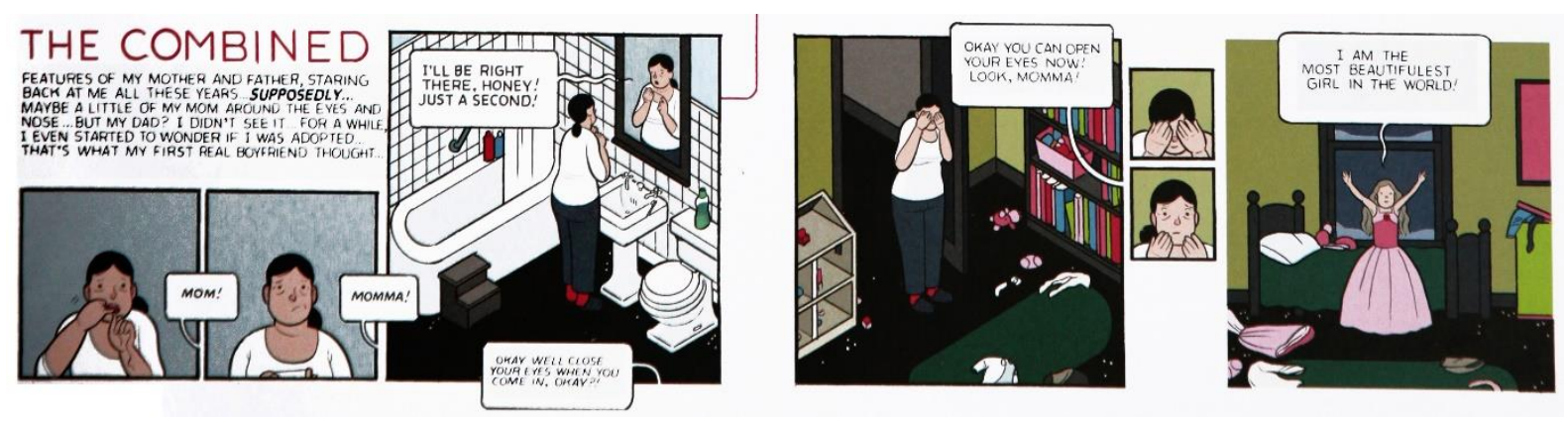

Fonte: WARE (2012)

\title{
Tradução:
}

"Os traços combinados da minha mãe e do meu pai, me encarando de volta depois de todos esses anos... Supostamente... Talvez um pouco da minha mãe em torno dos olhos e nariz... Mas o meu pai? Eu não conseguia ver... Durante um tempo, eu até comecei a achar que era adotada... Era isso que meu primeiro namorado de verdade achava..."

\author{
“Mamãe! Mamãe!” \\ "Já vou em um segundo, querida!" \\ "Ok, bem, fecha os olhos quando vier, tá?" \\ "Ok, você pode abrir os olhos agora, mamãe!" \\ "Eu sou a garota mais lindíssima do mundo!"
}

Ao longo da narrativa, a protagonista apresenta o querer-ser. Ela busca uma definição de si, com suas expectativas sendo mediadas também pelas noções normativas de uma aparência atraente (suas referências são mulheres ricas, estrelas e modelos, figuras femininas ligadas à cultura da celebridade), o que gera ansiedade, visto que os perfis imaginados se encontram distantes da realidade ("mãe atarracada"), algo não experimentado da mesma maneira por meninos e homens, que sofrem menos pressões para se encaixarem no mesmo perfil. Durante a infância, no entanto, ela não possui o saber, o conhecimento necessário que lhe permita conhecer mais profundamente a si mesma.

O olhar sobre si mesma (enviesado pelas inseguranças e desejos) permite que a protagonista crie uma imagem de si. Ela, assim, se mostra capaz de fazer-ser, se tornar, por 
meio da sua expressão artística, a mulher que ela deseja. O professor, no entanto, executa um fazer interpretativo no qual determina que ela não é e não parece, desmascarando-a publicamente, o que lhe causa constrangimento e frustração.

A reação da protagonista apresenta frustração e raiva, assim como não ela não refuta imediatamente o comentário homofóbico de Steve (apesar de ser capaz de perceber o quão condenável foi o seu comportamento, na narração), mostrando a sua insegurança com a própria deficiência física e sua percepção de seu corpo e aparência. O que se observa é a sua dificuldade em lidar com aquilo que pode ser caracterizado como um estigma:

Em vez de se retrair, o indivíduo estigmatizado pode tentar aproximar-se de contatos mistos com agressividade, mas isso pode provocar nos outros uma série de respostas desagradáveis. Pode-se acrescentar que a pessoa estigmatizada algumas vezes vacila entre o retraimento e a agressividade, correndo de um para a outra, tornando manifesta, assim, uma modalidade fundamental na qual a interação face-to-face pode tornar-se muito violenta. (GOFFMAN, 2008, p. 27)

Incapaz de se transformar nas mulheres idealizadas, a protagonista passa por um processo de descoberta de si mesma, percebendo seu corpo nu ou encarando-se novamente no espelho. Cria-se, então, uma consciência de sua identidade, despida de sonhos ou medos. Sua aceitação (ou resignação) dessa realidade não é totalmente clara, mas o último quadro, com sua filha se julgando positivamente, apresenta outro sujeito que é e parece e se mostra capaz de aceitar-se como tal.

O olhar-se no espelho, presente nos quatro momentos da narrativa, mostra a relação do sujeito protagonista com o objeto de valor "beleza normativa" e sua busca, pontuada pela maneira como ela se vê. O sujeito protagonista quer-ser "bela", "misteriosa", "modelo", reproduzindo valores estéticos socialmente bem-vistos. Seu olhar sobre si, portanto, é acompanhado e conduzido por uma série de pressões externas sobre a sua aparência. Ela se olha no espelho, mas suas percepções são influenciadas por uma sociedade que apresenta parâmetros inalcançáveis de beleza para mulheres (o que é particularmente mais intenso com ela, que apresenta desde a infância uma deficiência física). Isso marca a sua insegurança na adolescência, ao tentar tornar-se, pela expressão artística, essa mulher desejada. O momento em que outro sujeito a desmascara apenas evidencia a sua disjunção com o objeto de valor, causando-lhe amargura. Durante o começo de sua vida adulta, a narração aponta para a persistência de sua insegurança e insatisfação, mas o olhar distancia-se da face e mostra o corpo 
de maneira explícita e sem o romantismo das aspirações infantis, apontando para a possibilidade de rejeição do objeto de valor "beleza normativa". A resignação com a situação de disjunção com o objeto de valor é sugerida nos quadros inferiores, pelo reconhecimento da sua aparência tal como ela é. Os últimos quatro quadros, no entanto, mostram a filha declarando-se bela. A ausência do espelho (instrumento utilizado para a protagonista julgar-se em relação aos valores desejáveis) nessas últimas cenas mostra o sujeito que está em conjunção com o objeto de valor "beleza", mas este objeto não é determinado por pressões sociais e sim pela consciência de si mesmo, sem comparar-se a outros sujeitos para determinar sua identidade.

\subsubsection{O paralelismo e a superposição como síntese da narrativa}

As duas histórias apresentam narrativas diferentes, mas complementares. Ambas lidam com as percepções do indivíduo sobre si e sobre os outros. Esses olhares, moldados pela memória, pelo desejo ou pela consciência, determinam a construção de sua identidade. Os dois lados repetem a ideia dessa identidade, construída, percebida ou descoberta, utilizando a organização do espaço da página como uma orientação para a leitura e interpretação.

A orientação acima $\rightarrow$ abaixo acompanha o percurso alteridade $\rightarrow$ não-alteridade $\rightarrow$ identidade. Isto permite identificar também o paralelismo temático, ainda que cada história trate de momentos diferentes da vida da protagonista e julgamentos sobre personagens distintos. Neste posicionamento, a incerteza (alteridade e não-alteridade) é reafirmada nos quadros iniciais, enquanto a consciência da identidade se apresenta nos quadros finais, indicando a possibilidade de repetição de comportamentos (história apresentada na Figura 23) ou o indivíduo aceitando-se como tal (história apresentada na Figura 36).

Foi explorado anteriormente, na narrativa da Figura 23, a relação da imagem central (semelhante a uma máscara) com a história como um todo. A história da Figura 36 apresenta também relação com o tema explorado. Apesar de não estar acompanhada da narração como na Figura 25, o desenho do rosto da protagonista possui setas ligadas a dois momentos na história: a sequência que a mostra no começo da vida adulta aponta a primeira instância no texto em que o sujeito protagonista se vê de forma não idealizada, enquanto a seta inferior liga-se à consciência de quem ela é (seu rosto com traços não tão cartunescos, mostram suas marcas de 
expressão, semelhante ao quadro final da história anterior). A imagem, portanto, aproxima-se da identidade.

Figura 42

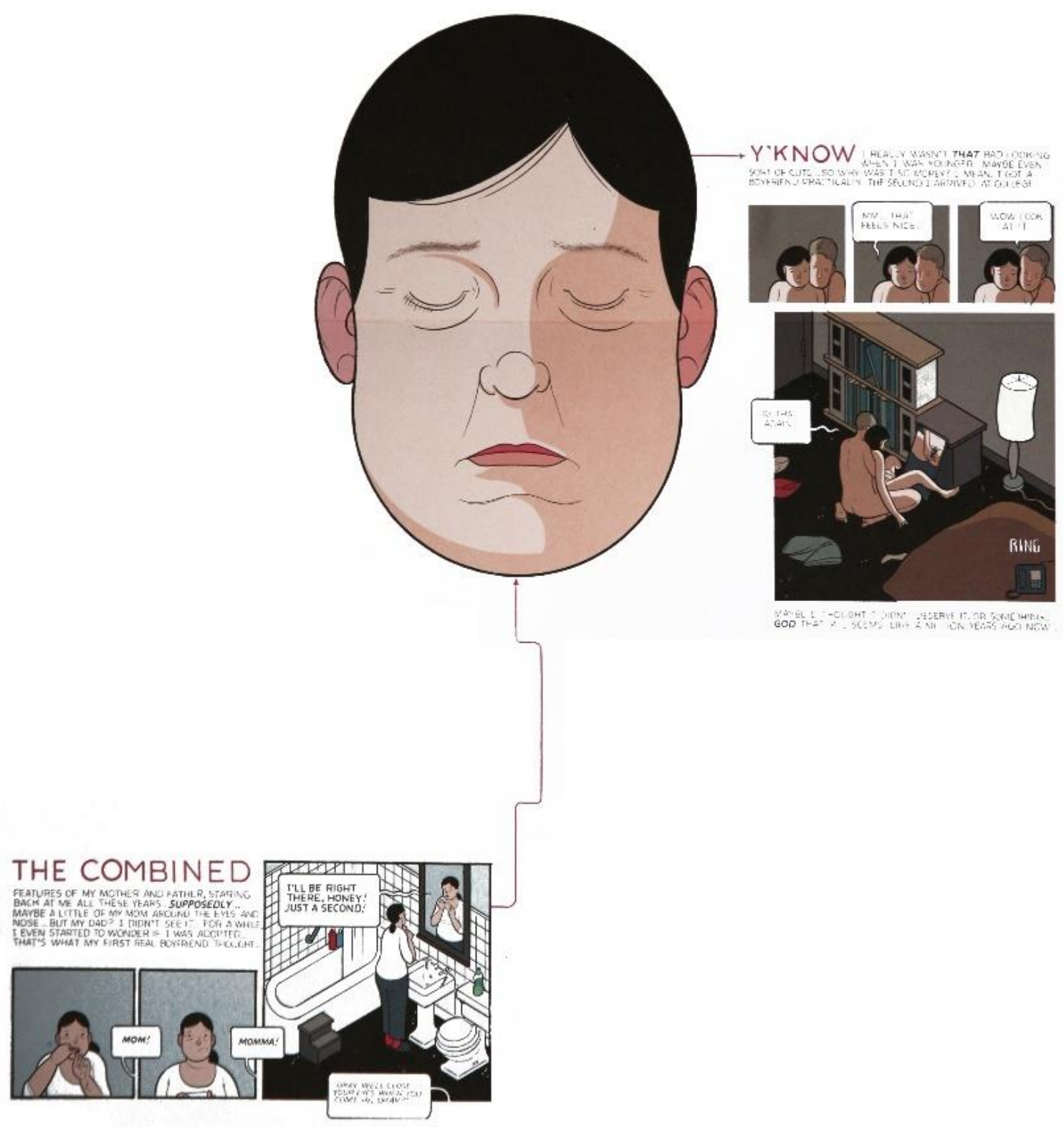

Fonte: WARE (2012). Montagem da autora.

Retomando o que foi já explorado no item 2.2.1, a imagem central, a "máscara", reafirma a percepção da protagonista, influenciada pela nostalgia. Aquilo que ela "vê" tem a interferência de suas memórias, da figura do amigo construída por fragmentos de suas lembranças. A imagem, que apresenta além da narração, as figuras em traços e reticulada de Steve, aproxima-se da alteridade. 
Figura 25

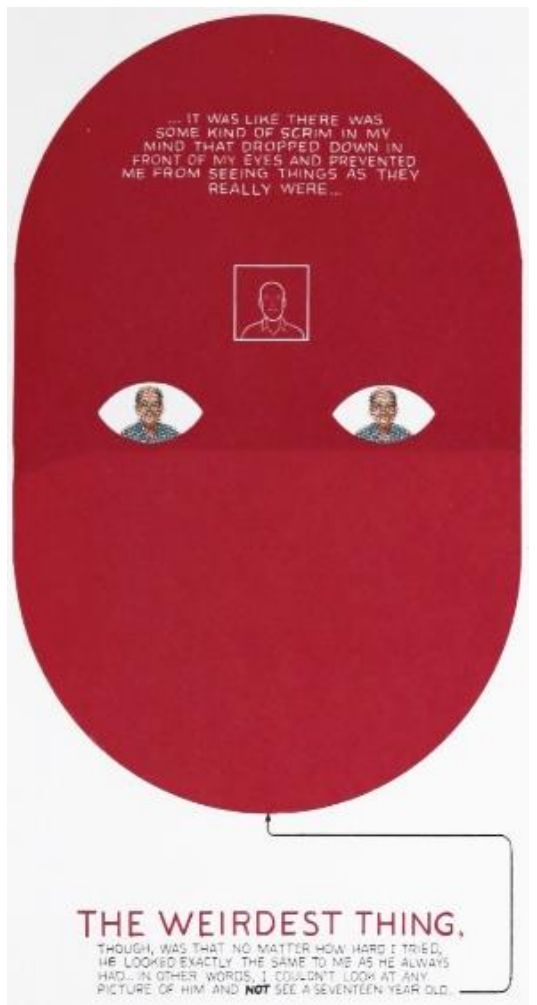

Fonte: WARE (2012)

O posicionamento das imagens, no centro da folha, é significativo para estabelecer a relação entre as duas narrativas e sua complementaridade. Ao contrário das outras partes da história, elas não apresentam a limitação do quadro. Diametralmente opostas na folha de papel, é possível percebê-las como a frente e o verso uma da outra. A sobreposição das imagens permite uma visualização mais clara:

Figura 43

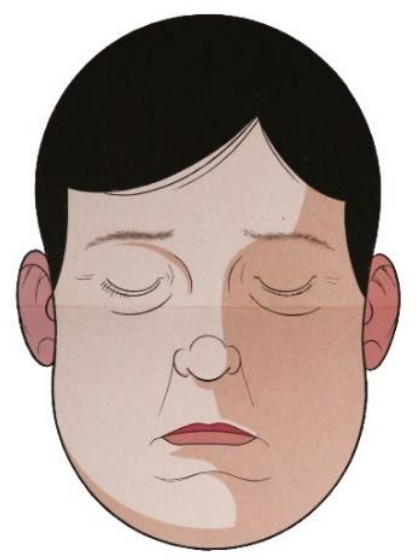

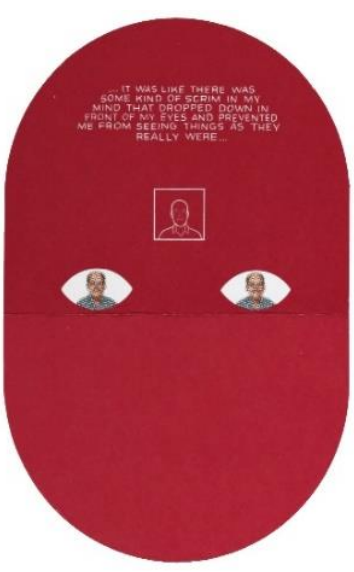

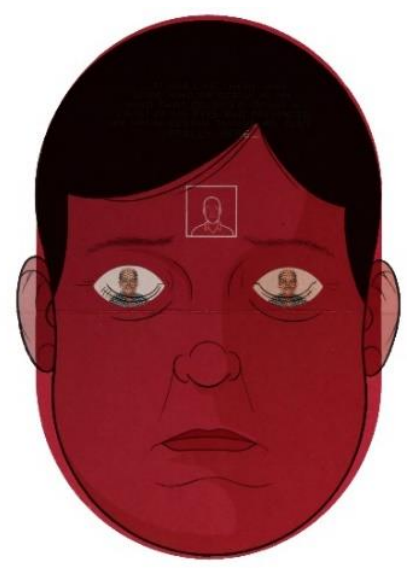

Fonte: WARE (2012). Montagem da autora 
Outro elemento significativo são os olhos nas duas ilustrações: enquanto o rosto do sujeito se mostra com os olhos fechados, a "máscara" possui os olhos abertos. É possível olhar para si com os olhos abertos, mas aos olhos fechados atribui-se a reflexão, a meditação, o olhar íntimo e “interior”. Os olhos abertos, por sua vez, percebem aquilo que se apresenta à superfície, sendo passíveis de engano. A segunda história, na qual a face da protagonista é central na página, evidencia o caráter manipulador da visão com a presença do espelho ao longo da narrativa (complementando a imagem e história do verso).

Dois níveis do indivíduo são apresentados: de um lado, há aquele ligado à identidade, à consciência do sujeito que é e parece; por outro lado, há a percepção superficial, a aparência, a alteridade, aquilo que parece, mas não é, a face que é construída para e pelo outro. Goffman (2008), ao discorrer sobre a existência de uma "identidade social", descreve o primeiro contato com um estranho e a possibilidade de prever seus atributos; são feitas afirmações sobre o que ele deveria ser. O caráter imposto a esse indivíduo "poderia ser encarado mais como uma imputação feita por um retrospecto em potencial - uma caracterização "efetiva", uma identidade social virtual" (ibid., p. 12). À identidade social real, atribui-se o que é passível de prova. Identidade social e a real são passíveis de discrepâncias, levando a avaliações positivas ou negativas do indivíduo, considerando que, quando negativas, não necessariamente consideram todos os atributos indesejáveis do indivíduo, mas somente aqueles que se mostram incongruentes com o estereótipo criado para ele.

A presença das duas imagens mostra, portanto a dualidade da vida social e suas faces construídas, ocultas e conhecidas. O posicionamento das ilustrações, portanto, oferece uma síntese das histórias, evidenciando a identidade e a alteridade antes mesmo que se escolha uma ordem de leitura.

\subsection{Uma consideração sobre o tempo em Building Stories}

Conforme foi colocado no item 2.2, o planejamento gráfico da história em quadrinhos, cria diversos efeitos, entre eles, de aceleração e lentidão. Portanto, diferentes configurações do quadro apresentam, plasticamente, efeitos de aceleração e desaceleração. Zilberberg (2006, p. 137), define a aceleração e desaceleração pelos conceitos de cronotrofia e cronopoiese: 
O poder de configuração do fazer missivo não é menor para o espaço do que para o tempo. Por uma razão óbvia porém inconcebível, tudo se passa como se o tempo e o espaço estivessem em razão um do outro:

- Toda remissão pode se configurar como uma cronopoiese, "implosão" em relação ao tempo e como fechamento quanto ao espaço.

- Toda emissão pode se configurar como cronotrofia em relação ao tempo e como abertura quanto ao espaço

Apesar das definições de Zilberberg serem aplicáveis a variadas formas de narrativa, é necessário tomar cuidado com a sua aplicação aos quadrinhos. É válido considerar que os estudos dos quadrinhos fora da semiótica observam que tempo e espaço também se encontram relacionados, sendo o espaço uma representação do tempo, conforme é explicado por Gravett (2013, p. 56, tradução nossa):

Tamanho realmente importa em quadrinhos, não apenas por quanto mais ou menos se pode colocar dentro de um quadro, mas porque é o meio no qual tempo é igual a espaço. Como regra geral, quadros menores tendem a representar períodos mais curtos de tempo e, portanto, podem ser ideais para comunicar um processo ou uma sucessão mais rápida de eventos próximos em um período de tempo.

Essa consideração observa a relação de espaço com tempo sob o ponto de vista não do sujeito narrativo, mas sim do processo de leitura. Convencionalmente, quadros pequenos sugerem uma contração no espaço: reduzido, permite uma leitura mais rápida, na qual uma quantidade menor de elementos gráficos ou verbais precisa ser apreendida pelo leitor e a “aceleração" no processo de leitura provoca a percepção de uma aceleração no tempo. Em contrapartida, quadros maiores sugerem uma expansão no espaço e uma desaceleração no tempo: a ampliação do espaço gráfico permite a aplicação de mais detalhes pictóricos e de balões e caixas de texto com mais conteúdo verbal. Um espaço pictórico ampliado e detalhado convida a uma leitura "mais lenta": a presença de mais elementos plásticos (além da sua disposição topológica no quadro maior, da página simples ou dupla) "retém" o olhar e desacelera o processo de leitura, provocando a percepção de um tempo desacelerado.

Nos estudos semióticos, as relações de tempo e espaço nos quadrinhos foram exploradas por Portela e Tomasi (2012), ao observarem como a correlação entre tempo e espaço na missividade nas narrativas gráficas se dá de maneira distinta à relação proposta por Zilberberg, apresentando, de fato, uma inversão de equivalência: à cronopoiese, a expansão do espaço, descontinuidade; à cronotrofia, fechamento do espaço e continuidade. Em suas análises das histórias "Gino Amleto Meneghetti”, de Luiz Gê, e "Mumin e os invasores”, de Tove Jansson, os pesquisadores observaram que 
estamos diante de sujeitos cujas narrativas só ganham figurativamente em abertura espacial quando a remissividade vem à tona, ao contrário do que se esperaria que acontecesse de acordo com o modelo zilberberguiano, no qual a abertura equivale à emissividade e o fechamento, à remissividade.

[...] Embora o arranjo espaço-temporal zilberberguiano para a missividade possa dar conta da dimensão figurativa de um grande número de narrativas, sua contradição fundamental parece ser a de avaliar o fechamento espacial como sendo sempre da ordem do remissivo e, portanto, da esfera do antissujeito. Essa avaliação cria uma relação necessária entre medidas do tempo e do espaço, limitando a independência dessas duas dimensões do discurso e, de certo modo, desafiando um princípio conhecido na tradição da semiótica europeia a partir de Saussure: o princípio da arbitrariedade. (idem, p. 26)

Observe-se como Ware trabalha com o tempo na história analisada anteriormente:

Figura 11

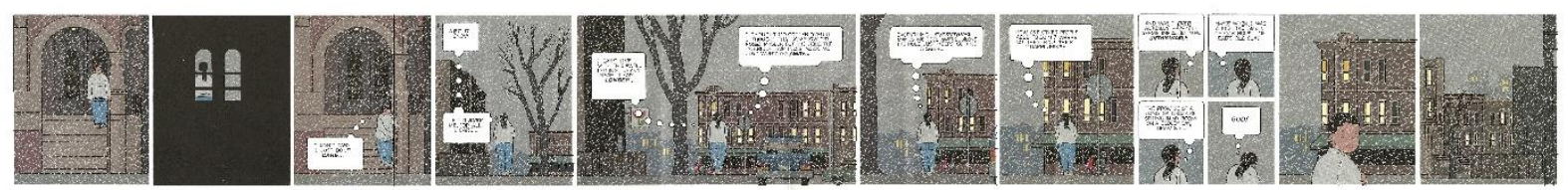

Fonte: WARE (2012)

Figura 12

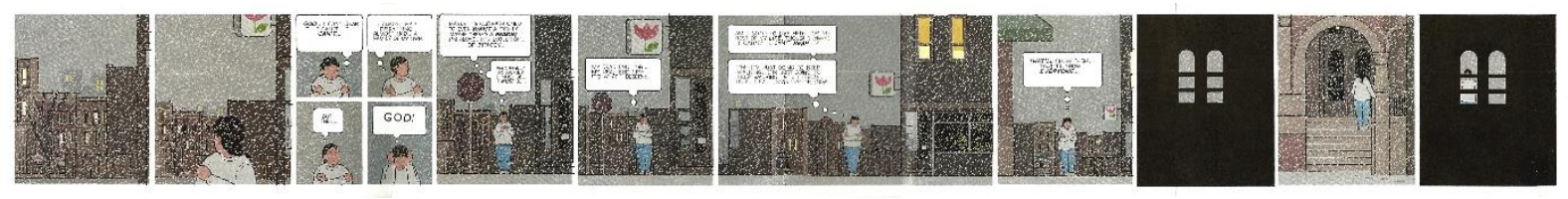

Fonte: WARE (2012)

Nesta história, os desejos da protagonista que apontam para uma ideia de futuro, felicidade, se apresentam como da ordem do emissivo. Este é definido na tensão entre o sujeito narrativo, figurativizado pela protagonista, e o objeto de valor, colocado como "feliz", "felicidade", "família". O sujeito em disjunção com o objeto de valor se mostra angustiado, o que é amplificado pelo fato de que não há indicação no texto da possibilidade de conjunção.

A posição da protagonista na rua deve ser considerada: quando está mais próxima do seu prédio (com seu interior escuro), ela se encontra em movimento; seu sentimento de frustração é mais intenso e esta insatisfação a move, motiva a sua busca por algo diferente da vida presente. Então, ela vai aos poucos se aproximando dos prédios com as luzes acesas, refletindo sobre a possibilidade de alcançar a felicidade, pensando na infância, nas 
oportunidades perdidas (e, assim como as luzes, tais ideias parecem distantes). Ela pausa e se mostra incapaz de seguir em frente, de se aproximar mais das luzes, retornando à frente do seu prédio. A incapacidade de entrar no prédio mostra como a insatisfação do sujeito com a própria vida não o deixa confortável em se manter onde está, enquanto o medo não lhe permite seguir em frente para obter aquilo que deseja.

Os quadros menores, nos quais a protagonista encontra-se mais próxima da identidade, reduzem o espaço e trazem a parada no tempo: enquanto os quadros maiores a integram ao cenário à sua volta (e sugerem a expansão do espaço), os quadros menores a isolam (com a eliminação de informações de cenário à sua volta), enquanto ela nostalgicamente reflete sobre sua infância ou sobre a oportunidade de ter uma família (por um breve momento, há o relaxamento da protagonista). Há pequena variedade de movimentos da protagonista, também, sugerindo que os pensamentos passam pela sua mente, ainda que brevemente, até que ela é novamente trazida à sua realidade e retorna ao movimento.

Dito isto, é possível perceber que, apesar da demonstração da relação cronotrofia fechamento do espaço - emissividade e cronopoiese - expansão do espaço - remissividade nos quadros menores e maiores, a remissão é predominante no texto. Observa-se que os espaços entre os quais o sujeito se alterna - em meio à sua dúvida sobre manter conjunção ou disjunção com o objeto de valor -, são espaços fechados (o prédio, as janelas das casas), enquanto o espaço ocupado de fato na narrativa é a rua, o espaço aberto. Topologicamente na história, isso é demonstrado no tamanho dos quadros. O enquadramento (que mostra a protagonista como que na mesma posição), por sua vez, cria o efeito de estaticidade da protagonista: ela parece não caminhar de fato, mas sim que o espaço se move à sua volta (ela se sente presa em sua insatisfação, apesar de outros serem capazes de "encontrar a felicidade"). O tempo passa, mas ela se vê presa em sua insatisfação e dúvida, incapaz de entrar em conjunção com o seu objeto de valor.

Ware também usa quadros menores como um recurso para dilatar o tempo. Gravett (2013, p. 60, tradução nossa) nota que:

Chris Ware descobriu que a inserção de grupos de quadros de mesmo tamanho, dividindo a altura do quadro regular em dois, é uma forma extremamente eficiente de representar transições ou ações, frequentemente mínimas e com um ponto de vista fixo, semelhante a animações em miniatura. 
A separação desses pequenos "frames" de tempo leva à leitura de cada quadro individualmente. Por meio desse recurso, cria-se a percepção de um momento breve sendo expandido, com uma pausa no tempo, como se percebe no trecho a seguir:

Figura 44

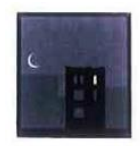

2 a.m

September 23 rd, 2000
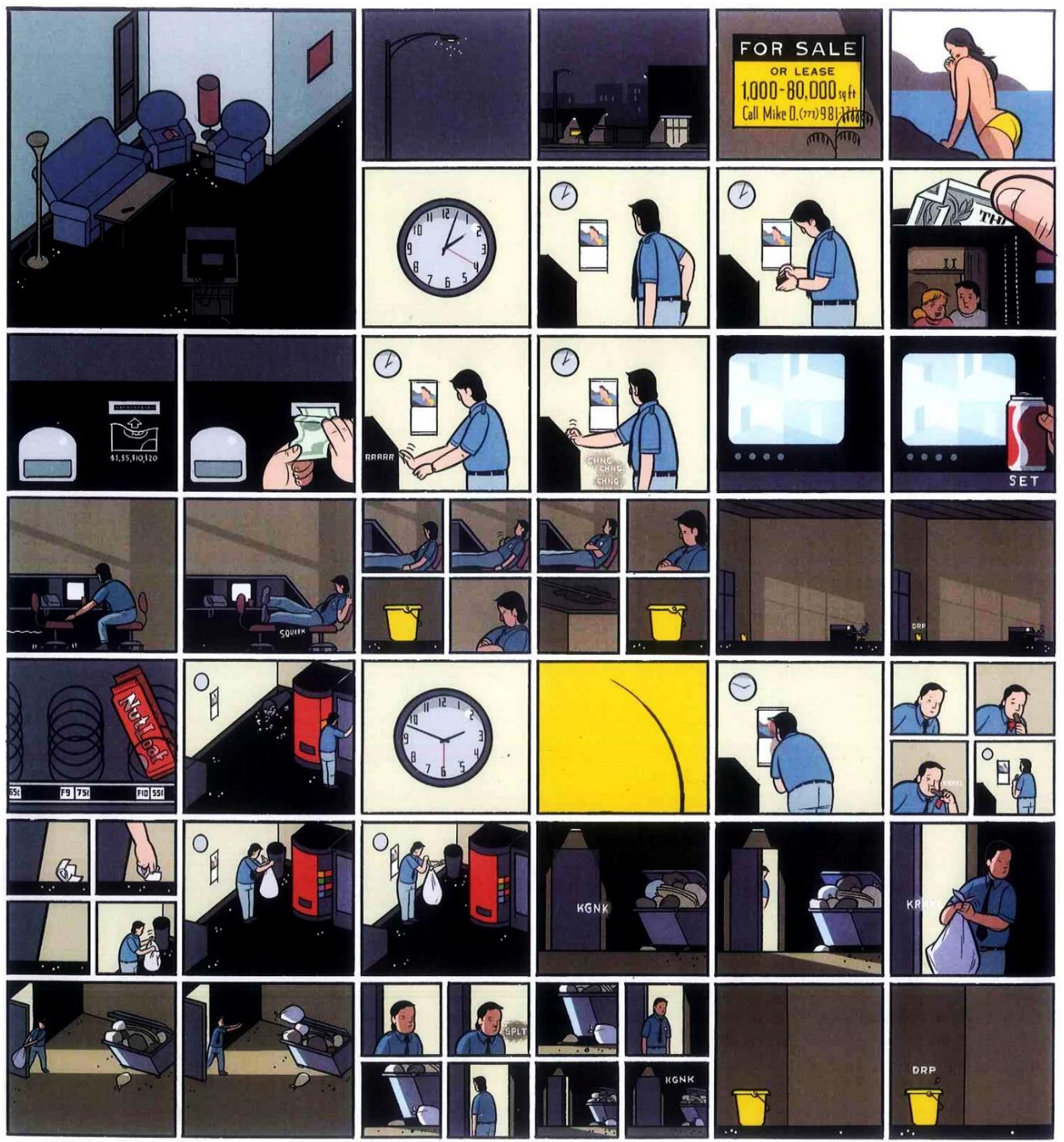

Fonte: WARE (2012) 
A sequência mostra os eventos que ocorrem durante o período de uma hora (a história em questão mostra o período de vinte e quatro horas na vida dos habitantes do prédio, sendo um deles o sujeito do trecho acima), com a marcação clara de dois momentos distintos: um, às 2 horas e 3 minutos e outro, às 2 horas e 48 minutos. O protagonista da história é um vigia, que aguarda pacientemente o fim da sua jornada de trabalho. $\mathrm{O}$ primeiro quadro estabelece a proporção inicial que determinará o tamanho dos quadros restantes. Os quadros reduzidos mostram pequenas mudanças: o sujeito procurando a sua carteira e retirando o dinheiro, colocando o dinheiro em uma máquina para retirar um refrigerante.

Há ainda quadros que apresentam uma segunda redução, como aqueles que mostram o protagonista sentado na sua cadeira, mordendo uma barra de doce, pegando um papel do chão. O espaço é ainda mais reduzido e as variações de movimento das cenas são mínimas, provocando a percepção de uma fragmentação da ação.

Figura 45
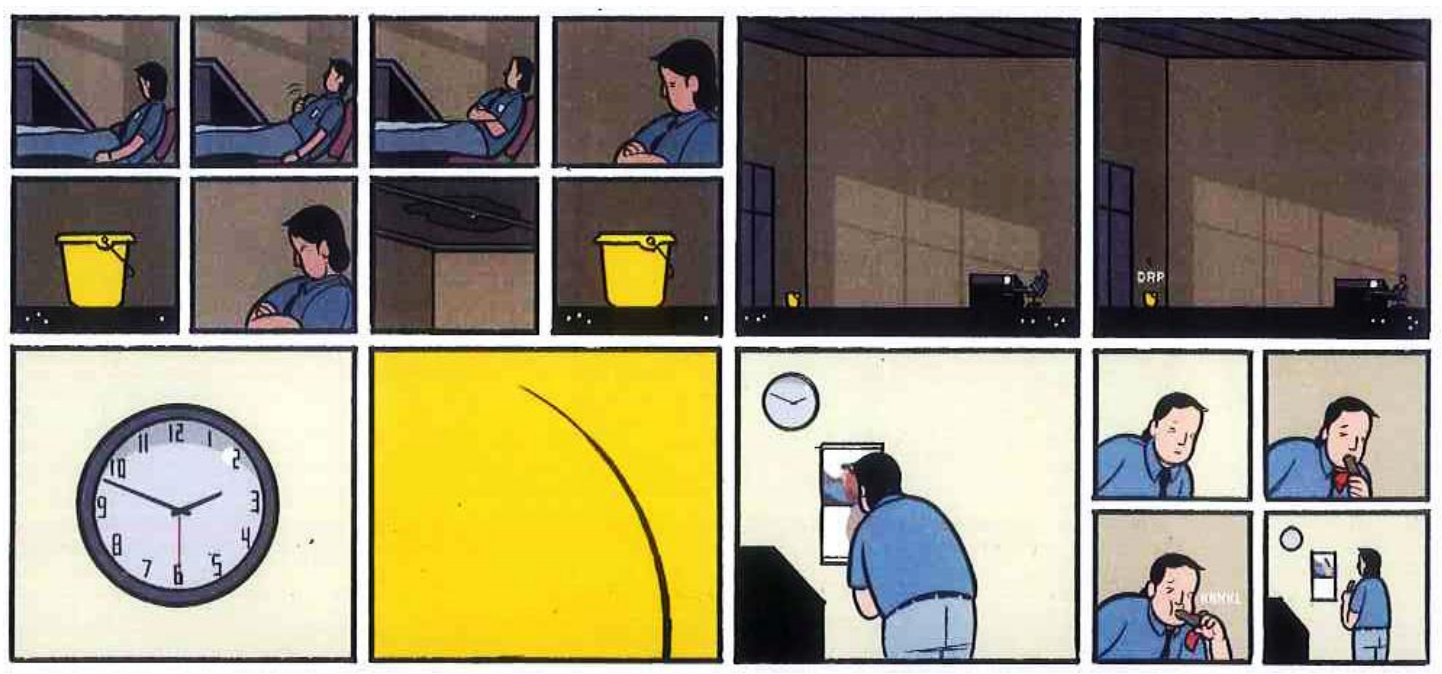

Fonte: WARE (2012)

Os quadros reduzidos marcam o fechamento do espaço e a remissividade, mas o tempo não parece andar. O primeiro quadro, o maior na sequência, mostra a sala de estar da casa do protagonista (lugar onde ele preferia estar). A partir do momento que ele se encontra em seu trabalho, tempo e espaço se contraem cada vez mais. Os dois momentos apresentados nos relógios mostram, cada um, a marcação de um minuto, muito embora não seja possível determinar a duração exata do tempo em cada uma dessas sequências, uma vez que o ponteiro do relógio parece não se movimentar em diversos quadros. O efeito de contração do espaço gráfico e sua aglutinação (além, é claro, da repetição de quadros quase idênticos), não criam o 
efeito de movimento e avanço da narrativa, mas sim o oposto: uma longa espera, na qual cada segundo é percebido, visto que aparece aqui a parada que o distancia de seu objeto.

A abordagem do tempo por Ware, portanto, não obedece necessariamente às convenções gráfico-narrativas dos quadrinhos, que Schneider (2016, p. 181, tradução nossa) observa como "uma relação relutante à imersão espacial e temporal e sua predileção à imobilidade, repetição e personagens do cotidiano". O autor manipula graficamente tempo e espaço para criar diferentes percepções de tempo, estas, dependentes de como se busca representar o estado emocional de seus personagens em seu contexto. 


\subsection{Fragmentação, interação e memória}

Building Stories é uma caixa com quatorze impressos, composta por quadrinhos de diferentes formatos e tamanhos. As histórias acompanham as vidas dos moradores de um edifício, com destaque para uma jovem solitária e melancólica, cuja vida é acompanhada antes, durante e depois de morar no edifício em questão. $\mathrm{O}$ verso da caixa apresenta o seguinte texto introdutório da obra:

Devido à crescente incorporealidade eletrônica da existência, às vezes é reconfortante - talvez até necessário - ter algo que se possa segurar. Portanto, dentro desta colorida caixa de lembranças o comprador encontrará uma variedade de materiais de leitura, prontos para atender praticamente qualquer gosto poético ou artístico imaginável, do sarcasmo corrosivo da juventude até a sinceridade nauseante da maturidade - enquanto se descobre uma protagonista imaginando se ela algum dia se mudará do alojamento fechado da solidão, na jovem vida adulta, para a vastidão hipotecada do amor e casamento -. Esteja você sentindo-se sozinho em sua companhia ou na companhia de alguém, este livro certamente simpatizará com o sentimento esmagador de vida desperdiçada, oportunidades perdidas e sonhos criativos abandonados que afligem o público literário de classe média e alta (sonhos estes que pode retornar a esse grupo em condições um tanto quanto avariadas durante o sono REM).

Uma listagem pictográfica de todos os 14 itens (260 páginas ao todo) aparece abaixo, incluindo sugestões de lugares apropriados para colocá-los, esquecêlos, ou até mesmo perder qualquer uma de suas partes entre as paredes de uma casa devidamente mobiliada. Conforme vistos nas páginas do The New Yorker, The New York Times e McSweeney's Quarterly Concern, Building Stories agrupa uma década de trabalho, com diversas páginas "nunca antes publicadas" (isto é, aquelas consideradas muito obtusas, obscenas ou só incoerentes para serem oferecidas a um periódico de respeito). (WARE, 2012, tradução nossa)

Os formatos de Building Stories compreendem um tabuleiro, um quadrinho de bolso, tiras de papel, um álbum de capa dura, um encadernado que se assemelha a um volume da coleção de livros infantis Little Golden Book, jornais, panfletos e impressos grampeados, com proporções de revista. Devido a seu formato inusitado, Building Stories coloca um problema para a classificação graphic novel, ao propor diferentes abordagens de leitura e a oportunidade dada ao leitor de "construir" a narrativa central, por meio da livre seleção de suas partes. 
Figura 46 - Building Stories aberto

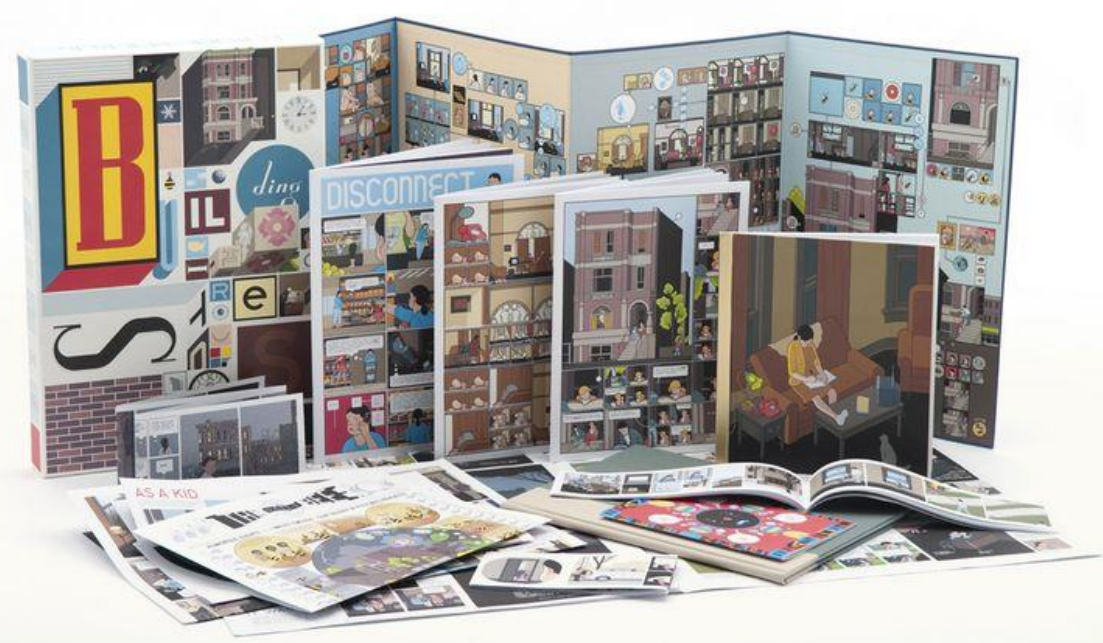

Fonte: WARE (2012)

Conforme colocado anteriormente, Ware utiliza-se de diversas referências além do quadrinho em seu processo criativo, tendo como influências a arquitetura, o design gráfico, a publicidade e as artes plásticas. Os diferentes impressos de Building Stories e seu armazenamento trazem à lembrança a Boîte-en-valise, ou Caixa-valise, do dadaísta Marcel Duchamp. A valise de couro contém 69 itens “de ou por Duchamp ou Rrose Sélavy”, incluindo as pinturas mais importantes do artista, como $\mathrm{Nu}$ descendo a escada (1912), e mais uma obra, esta original. O crítico de arte Calvin Tomkins (2013, p. 351), coloca que, "quando Walter Arensberg viu o objeto pronto em 1943, comentou que Duchamp havia inventado 'um novo tipo de autobiografia"”.

Figura 47 - Boîte-en-valise (1935-1941), de Marcel Duchamp

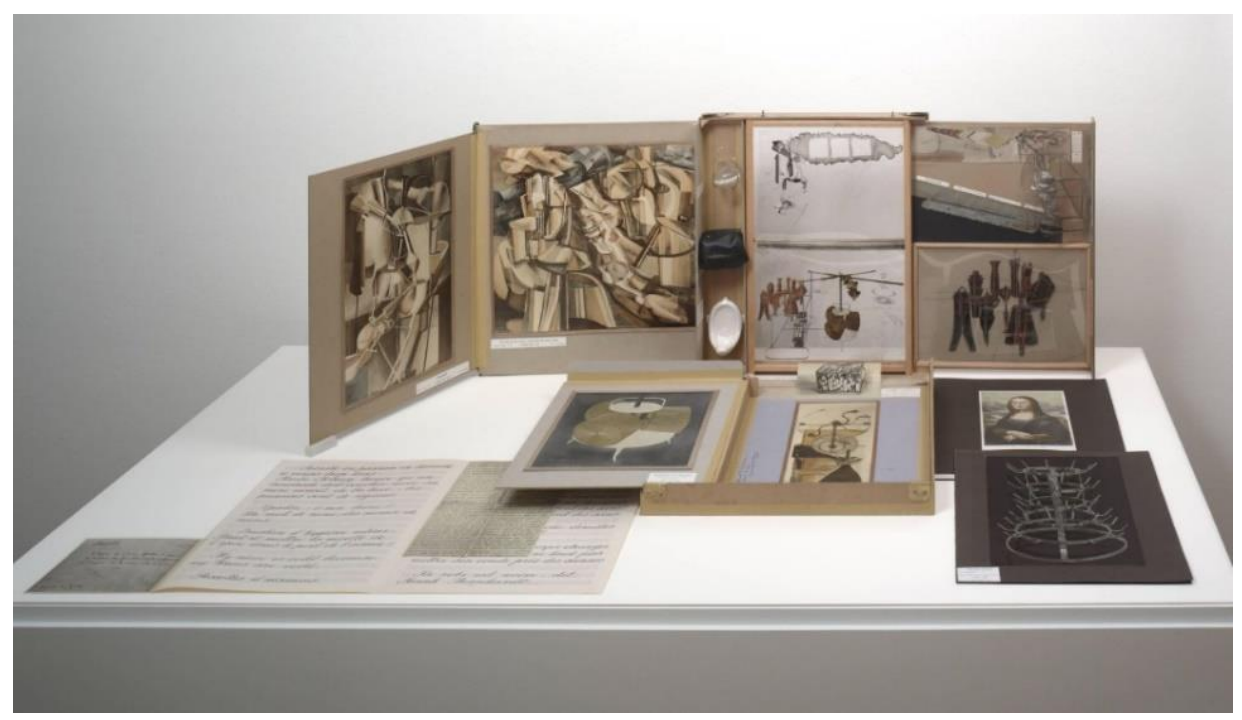

Fonte: DUCHAMP (1935-1941) 
Building Stories propõe uma "caixa de memórias" de outra ordem. Pela disposição de histórias fisicamente separadas, sem indicação de ordem de leitura, há diversas combinações que permitem construir a biografia de seus personagens aos poucos. Em entrevista para o site The Comics Journal (MAUTNER, 2012, tradução nossa), à época do lançamento de Building Stories, Ware justificou a escolha do formato, explicando:

Eu queria tirar mais proveito da forma como histórias e memórias estão disponíveis por todos os lados e momentos nas nossas lembranças, e não como parte de um contínuo; eu não acho que temos um "livro da vida" nos nossos cérebros, que nós folheamos para encontrar capítulos e passagens; nossa memória é mais como uma gema ou uma flor ou algo tridimensional que podemos manipular, virar do avesso, entrar e sair. E também, sendo um quadrinho, ele cresce do quadro para a página para o panfleto para, finalmente, um pacote ou presente.

Os formatos das histórias, por sua vez, acrescentam um aspecto interativo à obra de Ware, evidenciando seu caráter experimental, no qual se cria "uma demanda pelo engajamento físico e uma consciência da materialidade" (SCHNEIDER, 2016, p. 174, tradução nossa): não apenas as histórias devem ser escolhidas uma a uma, mas um tabuleiro deve ser desdobrado, a leitura de um quadro demanda a rotação do seu livro para que seja possível acompanhar o texto, histórias em impressos semelhante a cadernos de jornal exigem a aproximação e afastamento do olhar para que o espaço seja percebido tanto no detalhe quanto na sua totalidade. Tal exercício transforma a leitura em um ato cooperativo, porquanto trabalhoso. 
Figura 48 - página a lápis e nanquim de Building Stories, enquanto parte de história presente originalmente na ACME Novelty Library 18 (2007)

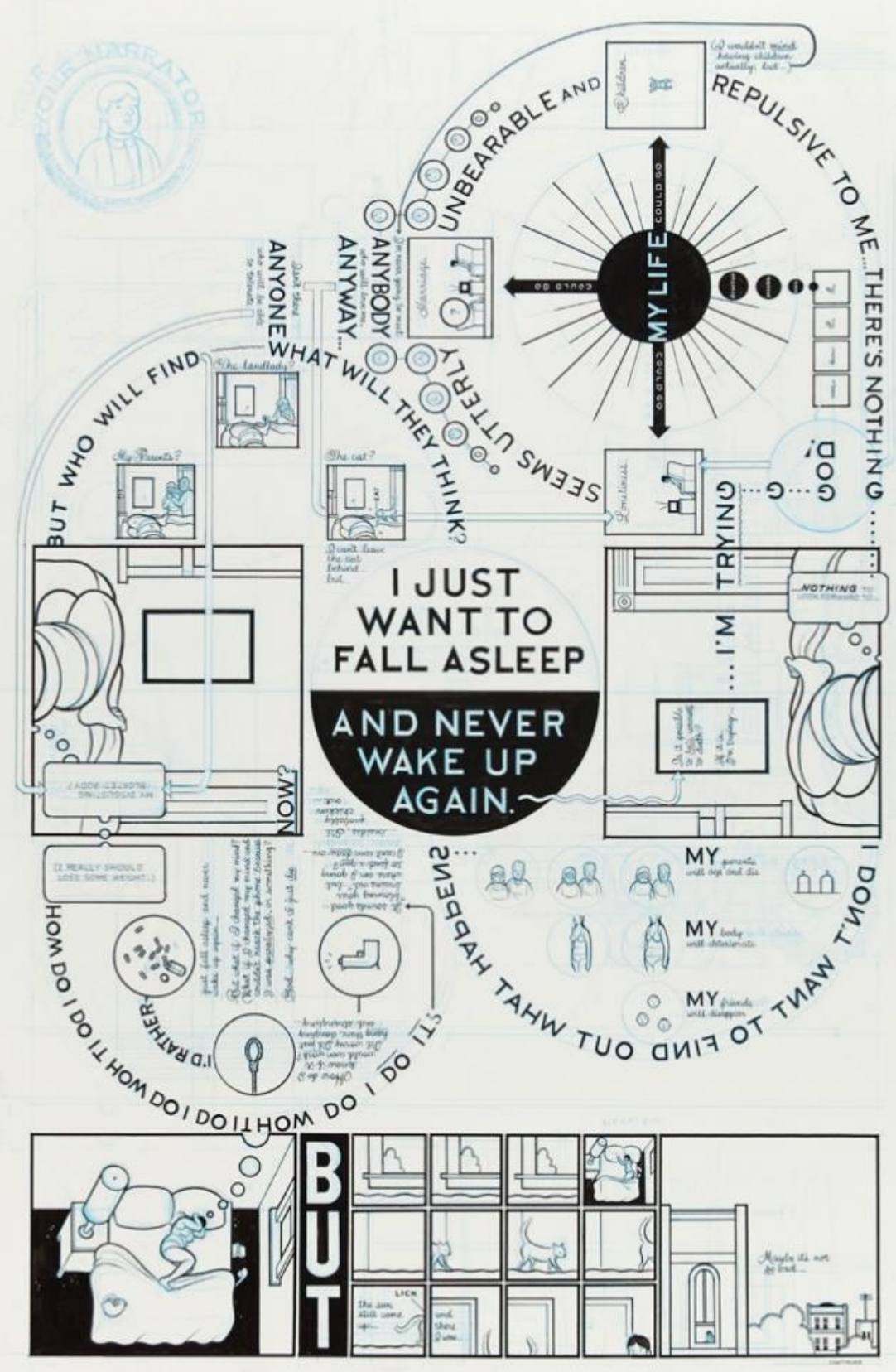

Fonte: WARE (2002).

Ware executa, em Building Stories, aquilo que Umberto Eco (1991) apresenta como "obra aberta": típico da arte e das vanguardas, tem por características ser afastada da univocidade, “apresenta-nos as coisas de um modo novo, para além dos hábitos conquistados, infringindo as normas da linguagem às quais havíamos sido habituados. [...] o discurso aberto 
se torna a possibilidade de discursos diversos, e para cada um de nós é uma contínua descoberta do mundo" (ibid., p. 280). Eco ressalta também que a característica do que chama de discurso aberto envolve cuidado particular para com a estrutura da obra: o "modo como se diz" se coloca como dotado de significado. A partir disso, "a mensagem não se consuma jamais, permanece sempre como fonte de informações possíveis e responde de modo diverso a diversos tipos de sensibilidade e de cultura" (ibid., p. 280). Esta arte, portanto, convida à renovação de percepções e estimula a mudança de perspectivas.

A maneira como Ware realiza isso é por meio da fragmentação da narrativa. Abrem-se possibilidades de diferentes abordagens e leituras da obra, sendo o ato de leitura ele mesmo dotado de significado. A proposta de fragmentação da narrativa por meio da linguagem dos quadrinhos não é nova, entretanto. Em 1989, Richard McGuire publicou Here (Figura 3) na antologia $R A W$ (e, posteriormente, no formato graphic novel em 2014). A história acompanha um mesmo espaço (o canto de uma sala) ao longo do tempo, com quadros mostrando desde 500.957.406.073 a.C., até 2033. A sobreposição e justaposição de quadros faz diferentes períodos no tempo conviverem no espaço da página. Observa-se, no nível do discurso, o uso da debreagem enunciativa espacial, com o espaço marcado pelo título da história, "aqui" (a representação do apartamento do autor), criando efeito de aproximação da cena enunciativa. $\mathrm{O}$ primeiro quadro não mostra nenhum personagem ou data, recuperando o agora e o eu ou $t u$. A partir desse quadro, o tempo é ancorado nas caixas de legenda que marcam cada ano: 1957 (ano do nascimento de McGuire), 1922, 1870, etc.. Todos os períodos no tempo relacionam-se ao agora do primeiro quadro. O espaço não muda, mas, embora as legendas apresentem diferentes datas, McGuire joga com a noção de presente, passado e futuro durante o ato de leitura dos quadrinhos. Gravett (2013, p. 62, tradução nossa) explica isso como

[...] diferentes durações de tempo podem transpirar entre quadros, grandes ou pequenos. Às vezes, enquanto lemos e examinamos através do painel, tanto a pergunta quanto a resposta, ou a causa e o efeito, podem ocorrer dentro do mesmo espaço único. Dentro desta área, o tempo se torna espaço, elástico e mutável, e o instante mais efêmero pode se expandir em toda uma vida diante dos seus olhos. Com narrativas compostas de imagens fixas, a arte dos quadrinhos é uma mídia como nenhuma outra ao nos permitir observar o passado, presente e futuro simultaneamente e permanentemente ao nos mover livremente pelas páginas, viajando no tempo enquanto viramos as folhas para frente e para trás, segurando toda uma vida em nossas mãos. Onde mais poderíamos ter a oferta de tal visão geral tanto da passagem quanto da sincronicidade do tempo? Esta é uma das formas como os quadrinhos parecem personificar nossos processos de pensamento associativo, fluidos, pelos quais nossos pensamentos, nossa atenção, podem estar no presente, no passado e no futuro a qualquer momento. 
Figura 3 - Primeira página de Here (1989), de Richard McGuire, publicada na antologia RAW.
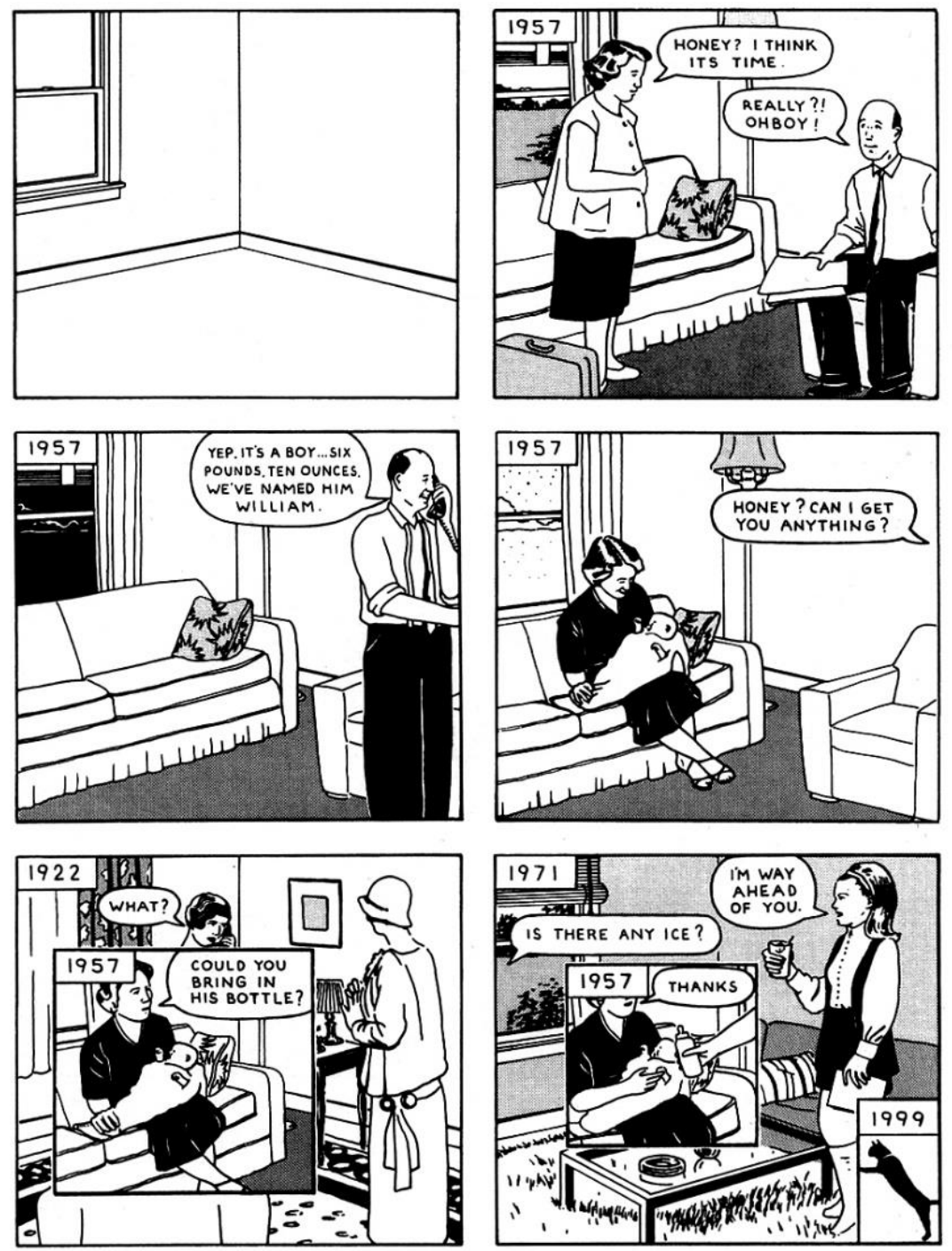

Fonte: McGUIRE (1989)

Constrói-se pela linguagem dos quadrinhos, portanto, uma embreagem temporal em Here, com a percepção de um tempo elástico, mutável e transitório, em que presente, passado e futuro são vividos simultaneamente. Here é uma das inspirações de Building Stories, com Ware descrevendo o quadrinho (em resenha à época do lançamento da graphic novel) como algo que

implodiu os limites da narrativa gráfica, e expandiu seu universo em um flash incendiário, introduzindo uma nova dimensão para a narrativa visual que se afastava radicalmente da leitura de cima para baixo e da esquerda para direita 
nos quadrinhos convencionais. E a estrutura era orgânica, apontando não apenas para o passado da mídia, mas também sugerindo o seu futuro. ${ }^{14}$

Enquanto a narrativa de Here ainda apresenta alguma conformidade com o formato padrão dos quadrinhos, apesar de subvertê-lo na sobreposição de quadros, Building Stories mostra aquilo que pode ser considerado o "futuro" ao qual Ware se referia: a experiência de leitura mais orgânica e interativa, pela fragmentação física da narrativa em impressos de diferentes formatos. Here apresenta uma estrutura a princípio linear, mas permite idas e vindas durante a leitura, com a conexão de momentos semelhantes (de mesma data, por exemplo) e o estabelecimento de suas relações sincrônica e diacronicamente. A fragmentação do tempo ocorre ainda dentro das limitações da página, respeitando os limites do seu suporte. Building Stories, por sua vez, também fragmenta o tempo, mas em uma estrutura que promove a leitura não linear: as histórias individuais possuem o seu sentido, lidas isoladamente. A leitura do conjunto, porém, permite observar seus personagens sob diferentes pontos de vista, de acordo com a ordem escolhida; suas identidades e relações são construídas conforme se avança na leitura.

Ware fala sobre memórias não pertencentes a um "contínuo". A proposta de fragmentação de Building Stories, coloca a oposição entre continuidade vs. descontinuidade, seja observando vida e memória em oposição, ou até mesmo o processo de leitura. A vida apresenta continuidade, fluxo, linearidade. A memória, porém, é o fragmento, a interrupção que retira o sujeito do fluxo constante e, no quadrinho, é apresentada como fruto de uma operação de triagem, com a seleção de episódios específicos ${ }^{15}$. O leitor deve escolher cada história e lêla separadamente, sendo cada uma delas parte de um todo, o quadrinho total. Joga-se com o ato de leitura dos quadrinhos: uma história convencional permite a fruição em um ritmo constante (uma história com "começo, meio e fim"). Building Stories torna a interrupção parte do processo de leitura. A apreciação dos fragmentos permite digressões e cria lacunas na

${ }^{14}$ WARE, Chris. Chris Ware on Here by Richard McGuire - a game-changing graphic novel. The Guardian. Disponível em: <https://www.theguardian.com/books/2014/dec/17/chris-ware-hererichard-mcguire-review-graphic-novel>. Acesso em 15 de maio de 2016. Tradução nossa.

${ }^{15}$ Em sua análise da memória e fragmentação presente em Infância, de Graciliano Ramos, Barros (2011, p. 79-86) observa que "A memória é veículo de sensações antigas que ganham materialidade ao tornarem-se imagem e, assim, lembrança. [...] A lembrança instaura a continuidade do passado no presente, enquanto o esquecimento produz a fratura. [...] O esquecimento também evidencia a falta de controle do sujeito recordador sobre sua memória. Por mais que ele se esforce, algumas lembranças permanecem ocultas.”. 
compreensão plena entre as histórias dos personagens, ficando a cargo do leitor interpretar os eventos ali apresentados e dar-lhes unidade.

\subsection{Fragmentação e combinação}

Building Stories oferece 87.178.291.200 possibilidades diferentes de leitura. A partir disso é possível concluir o seguinte: ao apresentar gama tão vasta de combinações, a preocupação do leitor não deve ser a busca de uma ordem ideal, ou que encapsularia perfeitamente a obra. A fragmentação em Building Stories indica que esse não é o seu objetivo. De fato, no próprio verso da caixa (Figura 49), o autor coloca o seguinte:

Uma listagem pictográfica de todos os 14 itens (260 páginas ao todo) aparece abaixo, incluindo sugestões de lugares apropriados para colocá-los, esquecêlos, ou até mesmo perder qualquer uma de suas partes entre as paredes de uma casa devidamente mobiliada. (WARE, 2012; tradução nossa)

Figura 49 - Verso da caixa de Building Stories

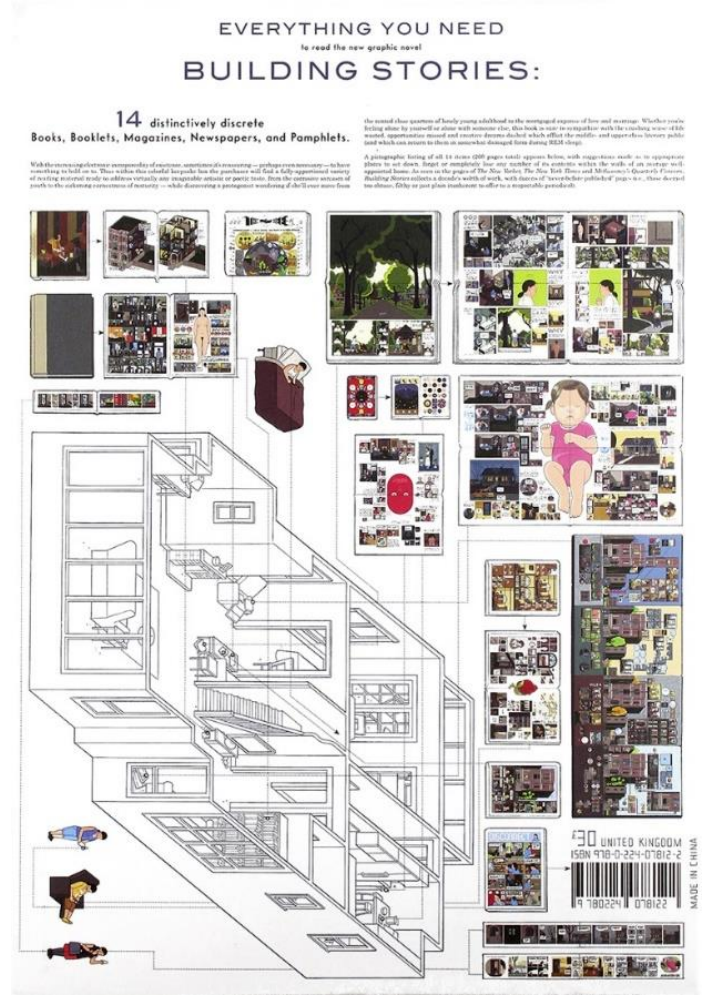

Fonte: WARE (2012). 
Ao afirmar que o leitor pode distribuir os impressos (e até mesmo perdê-los) em sua casa, Ware adianta como nem mesmo ele irá propor uma ordem de leitura e, se o leitor quiser organizar sua ordem a partir de onde posicionou cada item em sua moradia, isso será definido por como faz uso de cada um dos cômodos e de qual maneira, algo muito particular de pessoa para pessoa. Há a possibilidade, no entanto, para o leitor que se sentir inclinado, de organizar cronologicamente as histórias. Esse mesmo esse exercício, no entanto, pode ser difícil, uma vez que a cronologia de várias narrativas não é claramente estabelecida.

O título apresenta um jogo de palavras que dá uma pista sobre o que esperar do quadrinho. As definições de "building" são "edifício, estrutura" e também significa o "processo e trabalho de construção"16; enquanto as definições de "story" se apresentam como: "relato, história" e também é a variante norte-americana da palavra "storey"17, que significa "andar (de um prédio)".

O que se observa, portanto, é que Ware privilegia o processo de leitura ele mesmo e propõe uma leitura alternativa que depende da interação física do leitor com a obra. Ao apresentar bilhões de combinações, o autor cria uma história "sem fim" e uma experiência de conhecimento e reconhecimento das personagens que se dá aos poucos. Ware coloca a personagem das histórias analisadas anteriormente, uma jovem que não tem uma perna, como a protagonista, mas a história não se concentra apenas nela. Outros personagens são apresentados: a senhoria do edifício, um casal com problemas de relacionamento, uma abelha que vaga pelo espaço do prédio e até mesmo o edifício aparece como um personagem que possui seus pensamentos e anseios. Ao acompanharmos estas histórias, tem-se uma visão mais ampla do universo habitado pela protagonista.

\subsubsection{Sintagma e paradigma}

\footnotetext{
${ }^{16}$ building. Disponível em: < https://en.oxforddictionaries.com/definition/building>. Acesso em $15 \mathrm{de}$ setembro de 2017. Tradução nossa.

${ }^{17}$ storey. Disponível em: <https://en.oxforddictionaries.com/definition/storey>. Acesso em 15 de setembro de 2017. Tradução nossa.
} 
O Dicionário de Semiótica oferece a seguinte definição de sintagma (GREIMAS; COURTÉS, 2013, p. 469):

1. Designa-se pelo nome de sintagma uma combinação de elementos copresentes em um enunciado (frase ou discurso), definíveis, não apenas pela relação de tipo "e...e" que permite reconhecê-los, mas também por relações de seleção ou de solidariedade que mantêm entre si, bem como pela relação hipotáxica que os liga à unidade superior que constituem.

O termo compõe uma das dicotomias saussurianas, paradigma e sintagma. Esses termos definem as relações de seleção e de combinação entre os elementos linguísticos. O paradigma constitui a classe de elementos que podem ocupar um mesmo lugar em uma cadeia sintagmática, podendo substituir uns aos outros em um mesmo contexto (GREIMAS, COURTÉS, 2013, p. 358). O sintagma, por sua vez, apresenta-se sob uma forma "encadeada", sendo que nele não são combinados elementos aleatoriamente: essa combinação obedece um padrão que é definido pelo sistema (tomando como exemplo a língua).

Em sua explicação de relação sintagmática, Saussure (2006, p. 143) coloca que

uma unidade linguística é comparável a uma parte determinada de um edifício, uma coluna, por exemplo; a coluna se acha, de um lado, numa certa relação com a arquitrave que a sustém; essa disposição de duas unidades igualmente presentes no espaço faz pensar na relação sintagmática; de outro lado, se a coluna é de ordem dórica, ela evoca a comparação mental com outras ordens (jônica, coríntia, etc.), que são elementos não presentes no espaço: a relação é associativa $^{18}$.

As relações paradigmáticas, portanto, são aquelas em que o elemento selecionado exclui os demais da relação. Por isso, estas relações se dão in absentia, contrariamente às relações sintagmáticas, que ocorrem in presentia (pela presença dos elementos que se relacionam).

\subsubsection{A relação sintagmática em Building Stories}

\footnotetext{
${ }^{18}$ É possível notar que Saussure não utiliza o termo "paradigma". De fato, ele usa o termo "relação associativa", sendo o nome "paradigma" cunhado posteriormente pela Linguística para se referir às relações associativas entre signos.
} 
Compreendido o conceito de sintagma na língua, surge a dúvida de como poderia ser aplicado fora desse sistema. Barthes (2012, p. 80) fornece um modelo, tomando como exemplo o vestuário: esse sistema é composto por peças que podem ser usadas ao mesmo tempo em diferentes partes do corpo, cuja variação incorre em mudanças no sentido da indumentária (chapéu de palha vs. gorro, sapato social vs. tênis, etc.); o sintagma desse sistema, portanto, seria a justaposição de elementos diferentes em um mesmo conjunto (como camiseta-bermudachinelo).

A proposta de Barthes abre janela interessante para a reflexão. A leitura de Building Stories se dá também de forma encadeada (não é possível ler simultaneamente duas histórias, por exemplo), mas a combinação de seus 14 itens pode se dar de forma aleatória. $\mathrm{O}$ autor não apresenta um plano de leitura e tampouco o leitor tem essa obrigação. Histórias podem ser lidas com ou sem repetições, sendo que, em alguns casos, a construção da própria história permite que o leitor fique "preso" indefinidamente em uma narrativa. A partir da tabela de sistema e sintagma de Barthes (ibid., p. 80), propõe-se algo semelhante para identificar o sistema e sintagma em Building Stories:

\section{Sistema}

Grupo de 14 histórias, fisicamente separadas, com diferentes acabamentos e narrativas, compreendendo episódios na vida de 6 personagens. A leitura das histórias é linear, mas a escolha de cada texto pode ser feita aleatoriamente.

\section{Sintagma}

Encadeamento de histórias escolhidas de acordo com a vontade do leitor, criando a possibilidade de diferentes combinações a cada leitura.

Tomando cada história de Building Stories individualmente, pode-se considerar o que as aproxima (estilo de desenho, cores utilizadas, temática das histórias), mas é mais evidente o que permite criar entre elas relações de oposição (formatos e tamanho dos impressos, número de páginas, narrativas individuais). Uma vez tomada cada história como unidade sintagmática, busca-se verificar quais são as regras de combinação dentro do sistema. Essas combinações, apesar de numerosas, são finitas, com a mudança da ordem não afetando o sentido geral da obra, mas a escolha de uma ordem traz informações distintas a cada novo texto. 
Para aprofundar a compreensão sobre a relação sintagmática em Building Stories, considera-se o artigo escrito por Pietroforte (2016), no qual se encontra a análise do poema “canção da árvore de mil folhas", de Claudio Daniel:

o que exprime

essa esgrima silenciosa

esse pugilato de sombras?

simulacro de suave tigre de água e leo dragão de vento

flama de branca acácia e de salmão-pequeno

que combate no limiar entre a pele e a alma.

o que irradia

esse lento balé de plumas

esse desfile de facas e leques?

dança que traduz em passos de pantera

a canção da árvore de mil folhas

que não sabe da língua

mas do coração

Em sua análise, Pietroforte observa que o poema se encontra dividido em duas perguntas e suas respectivas respostas: [o que (exprime/irradia) (esselessa) X? Y]. X e Y, por sua vez, são sintagmas nominais de mesma estrutura sintática (um substantivo modificado por adjetivos simples, locuções adjetivas ou orações subordinadas adjetivas). Na formulação das perguntas, Pietroforte nota, não é possível saber se os sintagmas X e Y são sujeitos ou objetos dos verbos, decorrendo na indefinição de qual é a pergunta e qual é a resposta. O semioticista conclui: "Verifica-se, sob a linearidade prosódica, o objeto narrativo está definido em um labirinto semiótico" 19 .

Enquanto estrutura arquitetônica, o labirinto é o espaço da desorientação, aquele que contraria o linear. Conforme é colocado por Teixeira (2009), os labirintos têm sua origem atribuída a cultos religiosos da pré-História, com outras manifestações no Egito, Grécia, Oriente e Ocidente cristão. A natureza religiosa torna o labirinto uma representação da "confusão da

19 PIETROFORTE, Antonio Vicente. Livro dos Orikis. Musa Rara. Disponível em: <http://www.musarara.com.br/livro-dos-orikis>. Acesso em 21 de setembro de 2017. 
alma imersa no mundo profano e também a jornada cuja meta é a conquista espiritual" (ibid., p. 30). Com o passar dos séculos, porém, o simbolismo religioso do labirinto foi diminuindo e, em seu lugar, passou a ser valorizado o caráter lúdico e racional do labirinto enquanto um desafio à inteligência.

Na literatura, labirintos poéticos estão presentes no barroco português: são textos visuais que permitem uma pluralidade de leituras. Um labirinto poético, então, apresenta uma estrutura com diferentes caminhos de significação: ele demanda ser decifrado. Seu leitor deve apresentar não apenas um pensamento, mas um olhar particular àquilo que lhe é apresentado (ibid, p. 34).

Figura 50 - Poema visual do barroco português: Joseph Pereira Velozo, Desejos Piedosos de Huma Alma Saudosa, Lisboa, 1688

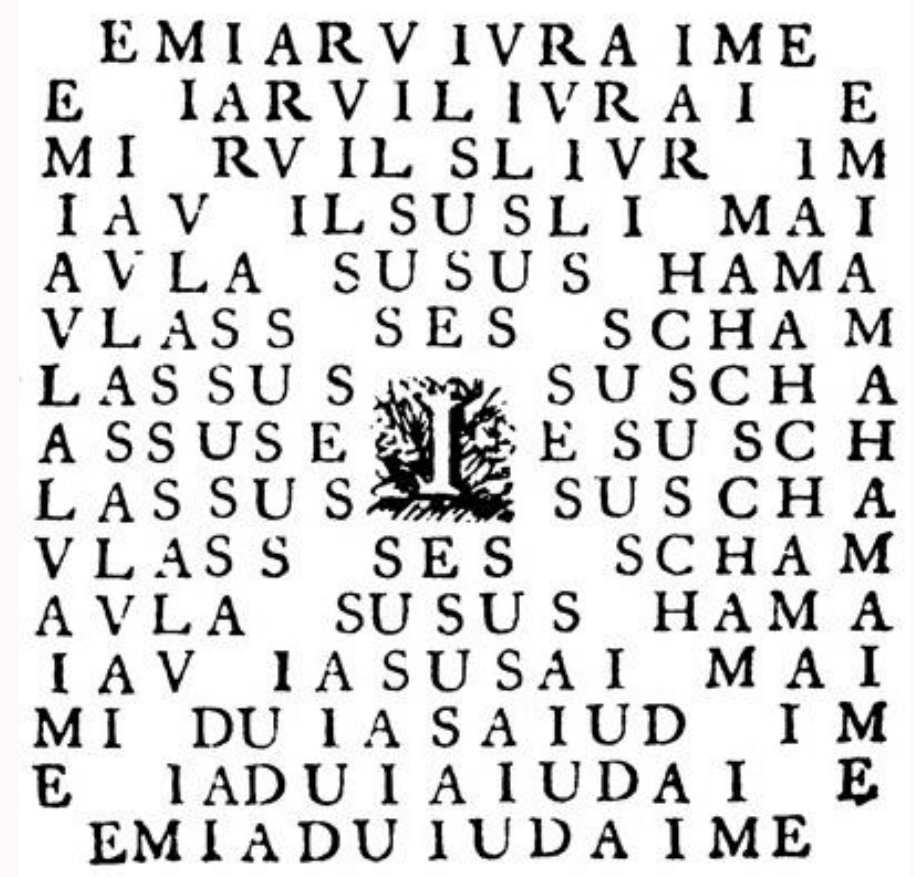

Fonte: HATHERLY (1983)

Retornando a Building Stories, observa-se que a história apresenta quatorze "entradas" e uma multiplicidade de caminhos a se percorrer na leitura. O formato do suporte é tão importante quanto as narrativas em si e suas coerções são determinadas pela configuração formal do quadrinho: não há leitura sem seleção e combinação. A obra se trata, pois, de um labirinto semiótico: as unidades sintagmáticas podem ser alternadas em qualquer ordem possível, sem que isso comprometa a compreensão do texto como um todo. Pelo contrário, o fato de que essa estrutura traz outras possibilidades de leitura e combinação acrescenta uma nova camada de sentido que aquela obtida apenas em uma leitura linear e convencional. 
Acrescente-se a isso o experimentalismo presente nas histórias individuais de Building Stories e o que se obtém é uma obra de complexidade singular, que subverte a maneira como se aborda a construção da narrativa gráfica e o seu ato de leitura. 
4. CONSIDERAÇÕES FINAIS 
A linguagem verbovisual dos quadrinhos encontra-se bem constituída e convencionada. Chris Ware, com seu repertório e habilidade, consegue manipular o sistema dos quadrinhos e seus componentes, criando novos sentidos que ultrapassam aqueles que a leitura convencional e linear propõe. Foi observado ao longo deste trabalho o vasto repertório do autor sobre as práticas dos quadrinhos, que sofisticaram as formas de sua linguagem até o momento presente. Ware se faz valer desse repertório ou subverte-o, explorando os recursos visuais da narrativa gráfica fora do padrão. A abordagem peculiar de Ware sobre a narrativa gráfica permite ir além da leitura da narrativa e considerar o ato de ler, ele mesmo, dotado de significação.

O experimentalismo de Ware, contudo, deve a seus antecessores: sejam os que fizeram parte do surgimento dos quadrinhos, ou os que promoveram a ruptura com as convenções, abrindo espaço para o trabalho autoral e experimental. As contribuições desses autores não apenas promoveram uma mudança na estrutura de mercado dos quadrinhos, como sua influência manifesta-se na obra dos autores contemporâneos.

A partir dos recortes feitos sobre os quadrinhos de Ware busca-se demonstrar não apenas a engenhosidade do autor, mas também as possibilidades de exploração que sua obra oferece para o pesquisador de semiótica. O experimentalismo do autor, ao se distanciar do modelo de construção textual convencional das narrativas gráficas, oferece campo fértil para que se testem as teorias semióticas. Espera-se, portanto, que este trabalho faça uma contribuição aos estudos semióticos sobre os quadrinhos, em particular os quadrinhos experimentais, apresentando exemplos e análises que, porquanto não satisfaçam a abordagem de toda a obra de Chris Ware, ofereçam possibilidade de diálogo com os estudos teóricos de quadrinhos e os estudos semióticos. 
REFERÊNCIAS 


\section{REFERÊNCIAS BIBLIOGRÁFICAS}

BALL, David M.; KUHLMAN, Martha B. (org). The comics of Chris Ware: drawing is a way of thinking. Jackson: University Press of Mississipi, 2010.

BARROS, Diana Luz Pessoa de. Teoria semiótica do texto. São Paulo: Ática, 2005.

BARROS, Mariana Luz Pessoa de. O discurso da memória: entre o sensível e o inteligível. 309 fls. Tese (Doutorado) - Faculdade de Filosofia, Letras e Ciências Humanas, Universidade de São Paulo, 2011.

BARTHES, Roland. Elementos de semiologia. Tradução de Izidoro Blikstein. São Paulo: Cultrix, 2012.

CAMARGO, Débora C. Ferreira. Fun Home: os efeitos de referencialidade na autobiografia de Alison Bechdel. 112 f. Dissertação (Mestrado) - Faculdade de Filosofia, Letras e Ciências Humanas, Universidade de São Paulo, 2013.

DUNCAN, Randy, SMITH, J. Matthew. The power of comics: History, form and culture. Nova York: Continuum, 2009.

ECO, Umberto. Obra aberta. São Paulo: Perspectiva, 1991.

EISNER, Will. Narrativas gráficas: princípios e prática da lenda dos quadrinhos. Tradução de Leandro Luigi Del Manto. São Paulo: Devir, 2013.

. Quadrinhos e arte sequencial: princípios e práticas do lendário cartunista. Tradução de Luis Carlos Borges e Alexandre Boide. São Paulo: Martins Fontes, 2015.

FIORIN, José Luiz. Elementos da análise do discurso. São Paulo: Contexto/Edusp, 2009.

FIORIN, José Luiz (org.). Introdução à linguística: I. Objetos teóricos. São Paulo: Contexto, 2015 .

FLOCH, Jean-Marie. Petites mythologies de l'œil et de l'esprit: Pour une sémiotique plastique. Paris: Éditions Hàdes-Benjamins, 1985. 
FONTANILLE, Jacques. Semiótica do discurso. Tradução de Jean Cristtus Portela. São Paulo: Contexto, 2015.

GOFFMAN, Erving. Estigma: notas sobre a manipulação da identidade deteriorada. Tradução de Márcia Bandeira de Mello Leite Nunes. Rio de Janeiro: LTC, 2008.

GOIDANICH, Hiron Cardoso. Enciclopédia dos quadrinhos. Porto Alegre: L\&PM, 1990.

GRAVETT, Paul. Comics Art. New Haven: Yale University Press, 2014.

GREIMAS, Algirdas Julien. Sobre o sentido II: ensaios semióticos. Tradução de Dilson Ferreira da Cruz. São Paulo: Nankin: Edusp, 2014.

GREIMAS, A. J.; COURTÉS, J. Dicionário de semiótica. Tradução de Alceu Dias Lima, Diana Luz Pessoa de Barros, Eduardo Peñuela Cañizal, Ignacio Assis da Silva, Maria José Castagnetti Sombra e Tieko Yamaguchi Miyazaki. 2. ed., $2^{\mathrm{a}}$ reimpressão. São Paulo: Contexto, 2013.

GROENSTEEN, Thierry. O sistema dos quadrinhos. Tradução de Érico Assis e Francisca Ysabelle Manriquez Reyes. Nova Iguaçu: Marsupial Editora, 2015.

HATFIELD, Charles. Alternative comics: an emerging literature. Jackson: University Press of Mississipi, 2005.

HATHERLY, Ana. A experiência do prodígio: bases teóricas e antologia de textos-visuais portugueses dos séculos XVII e XVIII. Lisboa: Imprensa Nacional Casa da Moeda, 1983.

HJELMSLEV, Louis. Ensaios linguísticos. Tradução: Antônio de Pádua Danesi. São Paulo: Perspectiva, 1991.

Prolegômenos a uma teoria da linguagem. Tradução de J. Teixeira Coelho Netto. São Paulo: Perspectiva, 1975.

JAKOBSON, Roman. Linguística e comunicação. Tradução de Izidoro Blikstein e José Paulo Paes. São Paulo: Cultrix, 2010. 
JAMESON, Fredric. Pós-modernismo: A lógica cultural do capitalismo. Tradução: Maria Elisa Cevasco. São Paulo: Ática, 1997.

MAUTNER, Chris. "I hoped that the book would just be fun": a brief interview with Chris Ware. The Comics Journal, 10 de outubro de 2012. Disponível em: <http://www.tcj.com/ihoped-that-the-book-would-just-be-fun-a-brief-interview-with-chris-ware/>. Acesso em $10 \mathrm{de}$ outubro de 2017.

MAZUR, Dan; DANNER, Alexander. Quadrinhos: História moderna de uma arte global. Tradução: Marilena Moraes. São Paulo: Editora WMF Martins Fontes, 2014.

McCLOUD, Scott. Desenhando quadrinhos. Tradução de Roger Maioli dos Santos. São Paulo: Makron Books, 2008.

Desvendando os quadrinhos. Tradução de Helcio de Carvalho e Marisa do Nascimento Paro. São Paulo: Makron Books, 2005.

OXFORD LIVING DICTIONARIES. Disponível em: < https://en.oxforddictionaries.com/>. Acesso em 15 de setembro de 2017.

PIETROFORTE, Antonio Vicente S.. Semiótica visual: os percursos do olhar. São Paulo: Contexto, 2004.

Análise textual da história em quadrinhos: uma abordagem semiótica da obra de Luiz Gê. São Paulo: Annablume, 2009.

O discurso da poesia concreta: uma abordagem semiótica. São Paulo: Annablume; Fapesp, 2011.

. Livro dos Orikis. Musa Rara. Disponível em: <http://www.musarara.com.br/livro-dos-orikis〉. Acesso em 21 de setembro de 2017.

PORTELA, Jean Cristtus; TOMASI, Carolina. Cronopoiese e cronotrofia na história em quadrinhos. Estudos Semióticos. [on-line] Disponível em: <http://www.fflch.usp.br/dl/semiotica/es>. Editores responsáveis: Francisco E. S. Merçon e Mariana Luz P. de Barros. Volume 8, número 2, São Paulo, Novembro de 2012, p. 21-27. Acesso em 20 de junho de 2017. 
RAEBURN, Daniel. The Smartest Cartoonist on Earth. The Imp, Chicago, v. 1, no 3, p. 1-19, 1999.

RAMOS, Paulo. A leitura dos quadrinhos. São Paulo: Contexto, 2014.

REBLIN, Iuri Andréas. O Alienígena e o Menino. Jundiaí: Paco Editorial, 2015

SCHNEIDER, Grace. What happens when nothing happens - Boredom and everyday life in contemporary comics. Leuven: Leuven University Press, 2016.

SMOLDEREN, Thierry. The origins of comics: from William Hogarth do Winsor McCay. Tradução de Bart Beaty e Frank Nguyen. Jackson: University Press of Mississipi, 2014.

TOMKINS, Calvin. Duchamp: uma biografia. Tradução de Maria Thereza de Rezende Costa. São Paulo: Cosac Naify, 2013.

KANNENBERG JR., Gene. The comics of Chris Ware. In: VARNUM, Robin, GIBBONS, Christina T. (org.). The Language of Comics: word and image. Jackson: University Press of Mississipi, 2001.

WARE, Chris. Building Stories. Nova York: Pantheon Books, 2012.

Chris Ware on Here by Richard McGuire - a game-changing graphic novel. The Guardian. Disponível em: <https://www.theguardian.com/books/2014/dec/17/chrisware-here-richard-mcguire-review-graphic-novel>. Acesso em 15 de maio de 2016.

. Cover story: moving images. The New Yorker. Disponível em: <https://www.newyorker.com/culture/culture-desk/cover-story-2015-12-07>. Acesso em $10 \mathrm{de}$ novembro de 2017.

Chris Ware, the art of comics no. 2. Entrevista concedida a Jeet Heer. The Paris Review. Nova York, $\mathrm{n}^{\circ}$ 210, 2014. Disponível em:

$<$ https://www.theparisreview.org/interviews/6329/chris-ware-the-art-of-comics-no-2-chrisware >. Acesso em 01 de fevereiro de 2017. 
ZILBERBERG, Claude. Razão e poética do sentido. Tradução: Ivã Lopes, Luiz Tatit, Waldir Beividas. São Paulo: Editora da Universidade de São Paulo, 2006.

\section{REFERÊNCIAS DAS FIGURAS}

CRUMB, Robert. The complete Zap Comix (2014). Disponível em:

< http://www.tcj.com/reviews/the-complete-zap-comix/>. Acesso em 21 de setembro de 2017.

DC COMICS: the 75th anniversary poster book. Quirk Books: Philadelphia, 2010.

DUCHAMP, Marcel. Caixa-valise. 1935-1941. Escultura, reproduções fotográficas, celuloide, gesso, porcelana, vinil, papel, madeira e compensado, dimensões ad lib. Coleção SFMOMA. Tradução de: La-boîte-en-valise. Disponível em: <https://www.sfmoma.org/artwork/81.40.AQQQ>. Acesso em 10 de outubro de 2017.

McGUIRE, Richard. Here. SPIEGELMAN, Art (editor). RAW, Vol. 2, no. 1: Open wounds from the cutting edge of commix. Penguin: 1989. Disponível em: <http://thebeautifulcomics.tumblr.com/post/99631361887/here-1989-by-richard-mcguire-rawmagazine>. Acesso em 21 de maio de 2016.

SPIEGELMAN, Art (editor). RAW, Vol. 2, no. 1: Open wounds from the cutting edge of commix. Penguin: 1989.

SPIEGELMAN, Art. The complete Maus. Londres: Penguin Books, 2003.

WARE, Chris. ACME 18 - I just want to fall asleep. 2002. Nanquim e lápis azul sobre papel, dimensões $73 \mathrm{~cm}$ por $50,8 \mathrm{~cm}$. Original exibido na Adam Baumgold Gallery (Nova York) em 2012. Disponível em: <http://adambaumgoldgallery.com/Ware/2012/building_stories.htm>. Acesso em 17 de maio de 2017.

ACME Novelty Library \#4. Seattle: Fantagraphics, 1995. Disponível em: <http://www.comicscube.com/2010/07/comics-techniques-and-tricks-chris-ware.html>. Acesso em 19 de agosto de 2017.

Building Stories. Nova York: Pantheon Books, 2012. 
I Guess (a.k.a. "Thrilling Adventure Stories"). SPIEGELMAN, Art (editor). RAW, Vol. 2, no. 3: High Culture for Lowbrows. Penguin: 1991. Disponível em: <http://gladyou-asked.blogspot.com.br/2010/01/ee-comics.html>. Acesso em 19 de agosto de 2017. 
Anexo 1A: História analisada no item 2.1. Tradução nossa.
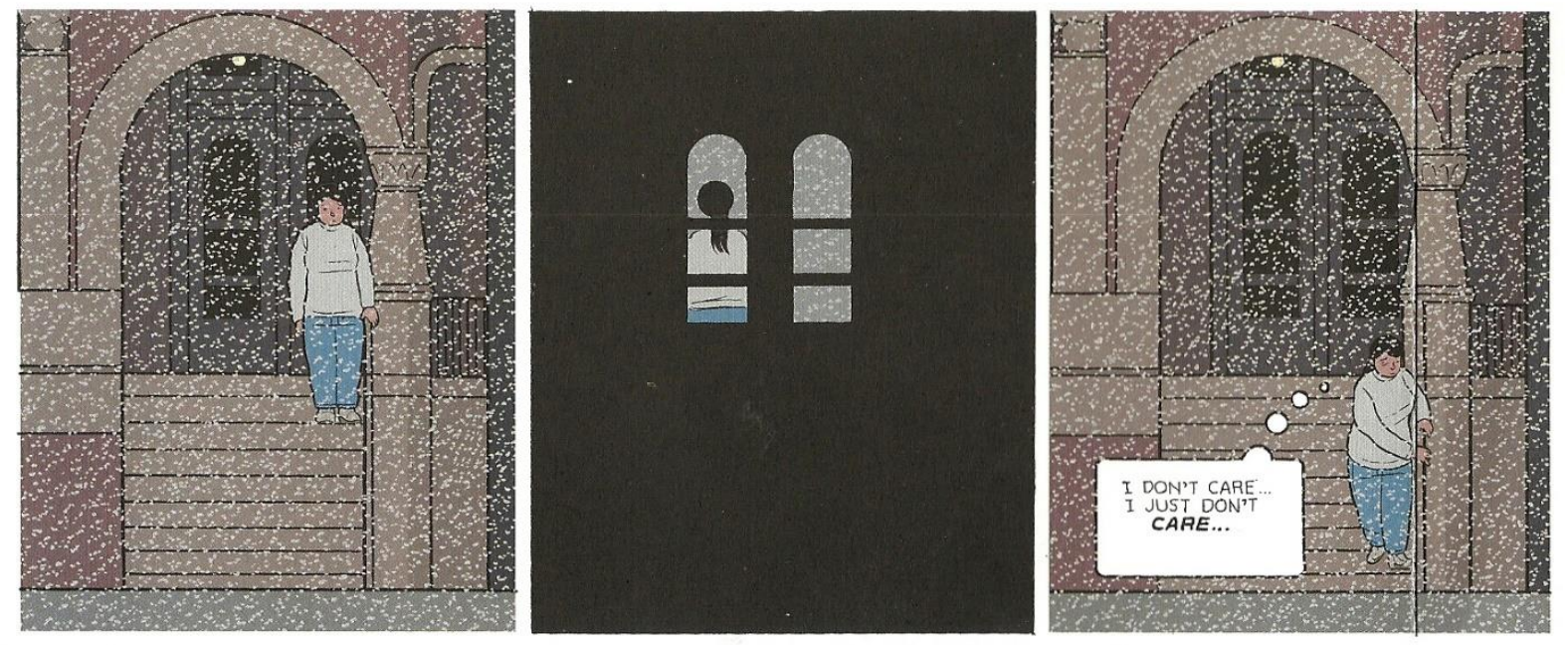

Eu não me importo... Eu simplesmente não me importo...
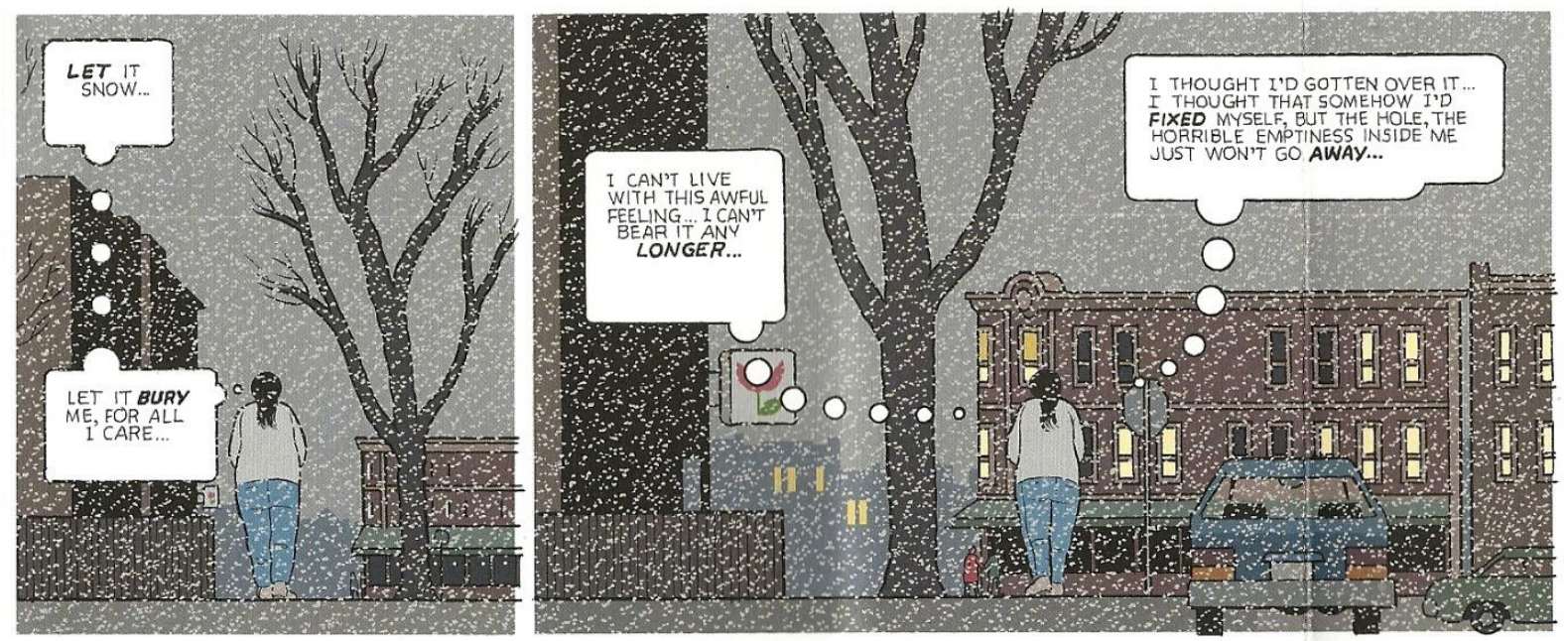

Deixe que neve... Deixe que me enterre, eu não ligo...

Eu não posso viver mais com esse sentimento horrível... Eu não consigo mais aguentar... Eu achei que teria superado... Eu achei que se eu tivesse de alguma forma me consertado, mas esse buraco, este vazio horrível dentro de mim apenas não vai embora... 

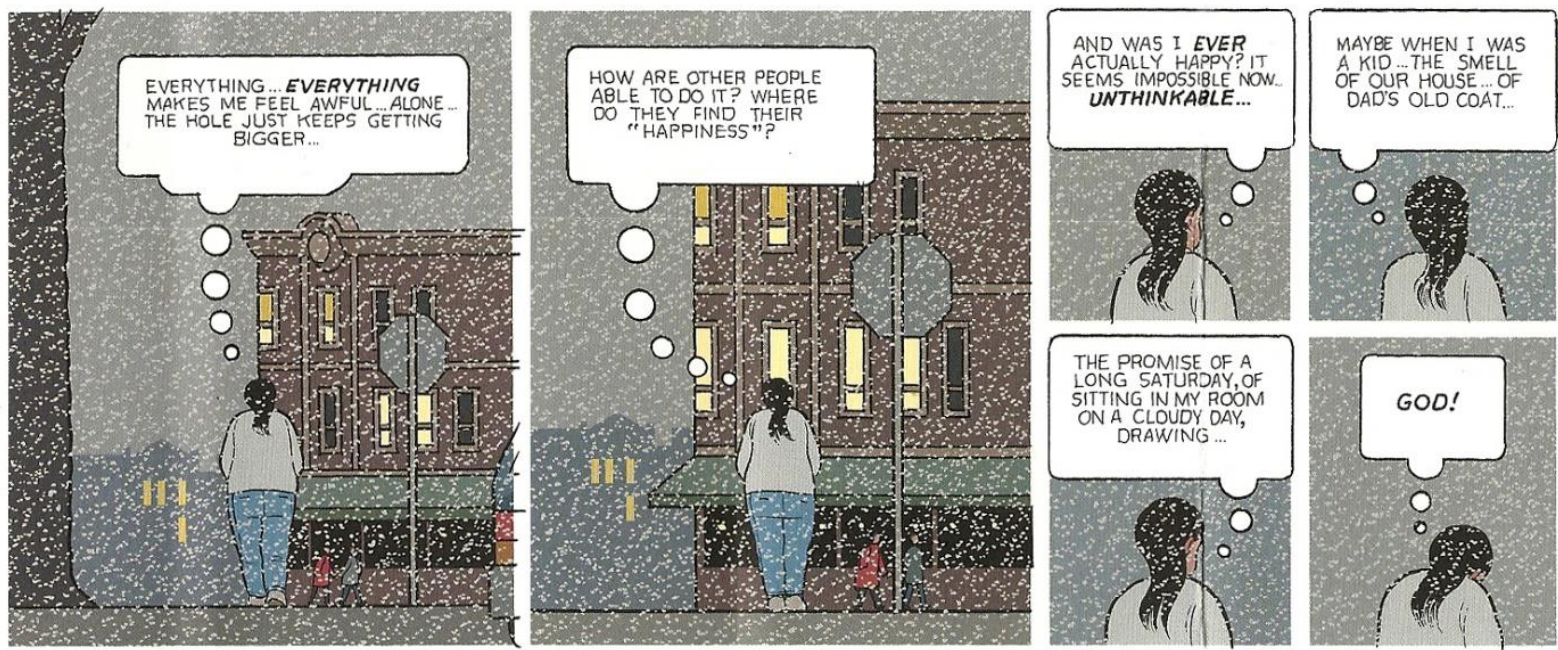

Tudo... Tudo faz com que eu me sinta horrível... Sozinha... O buraco só vai aumentando...

Como outras pessoas conseguem? Onde elas acham a sua "felicidade"?

E eu fui alguma vez verdadeiramente feliz? Parece impossível agora... Impensável...

Talvez quando eu era criança... O cheiro da nossa casa... Do velho casaco do papai...

A promessa de um longo sábado, sentada no meu quarto em um dia nublado, desenhando...

\section{Deus!}
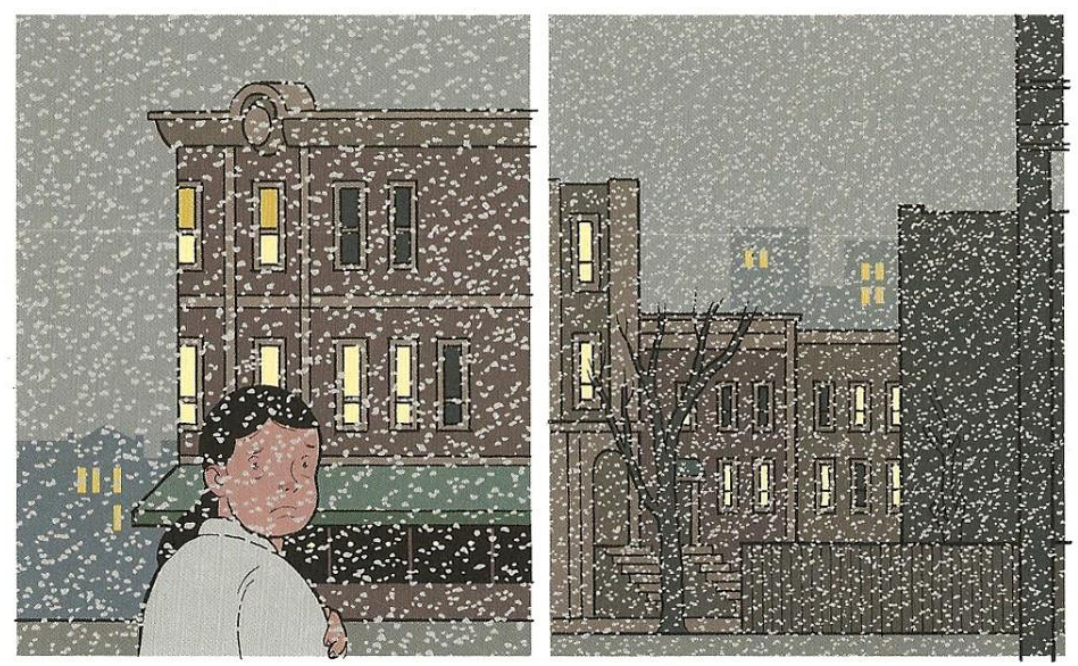
Anexo 1B: História analisada no item 2.1. Tradução nossa.
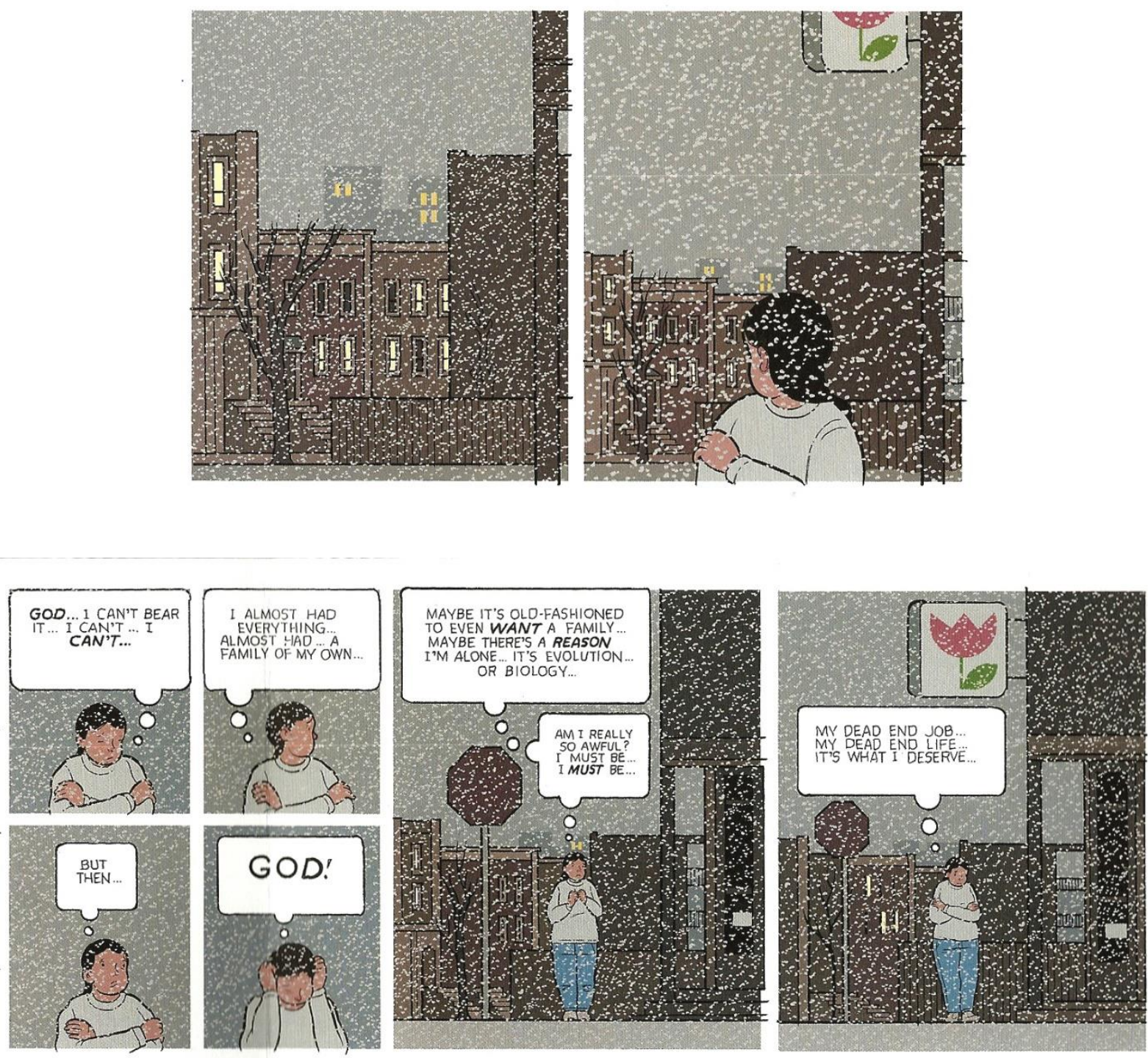

Deus.. Eu não posso mais aguentar... Eu não posso.. Não posso...

Eu quase tive tudo... Quase tive... Uma família minha...

Mas então...

\section{DEUS!}

Talvez seja antiquado até mesmo querer uma família... Talvez exista uma razão para eu ser sozinha... É evolução ou biologia...

Eu sou mesmo tão horrível? Eu devo ser... Eu devo ser...

Meu trabalho sem futuro... Minha vida sem futuro... É o que eu mereço... 

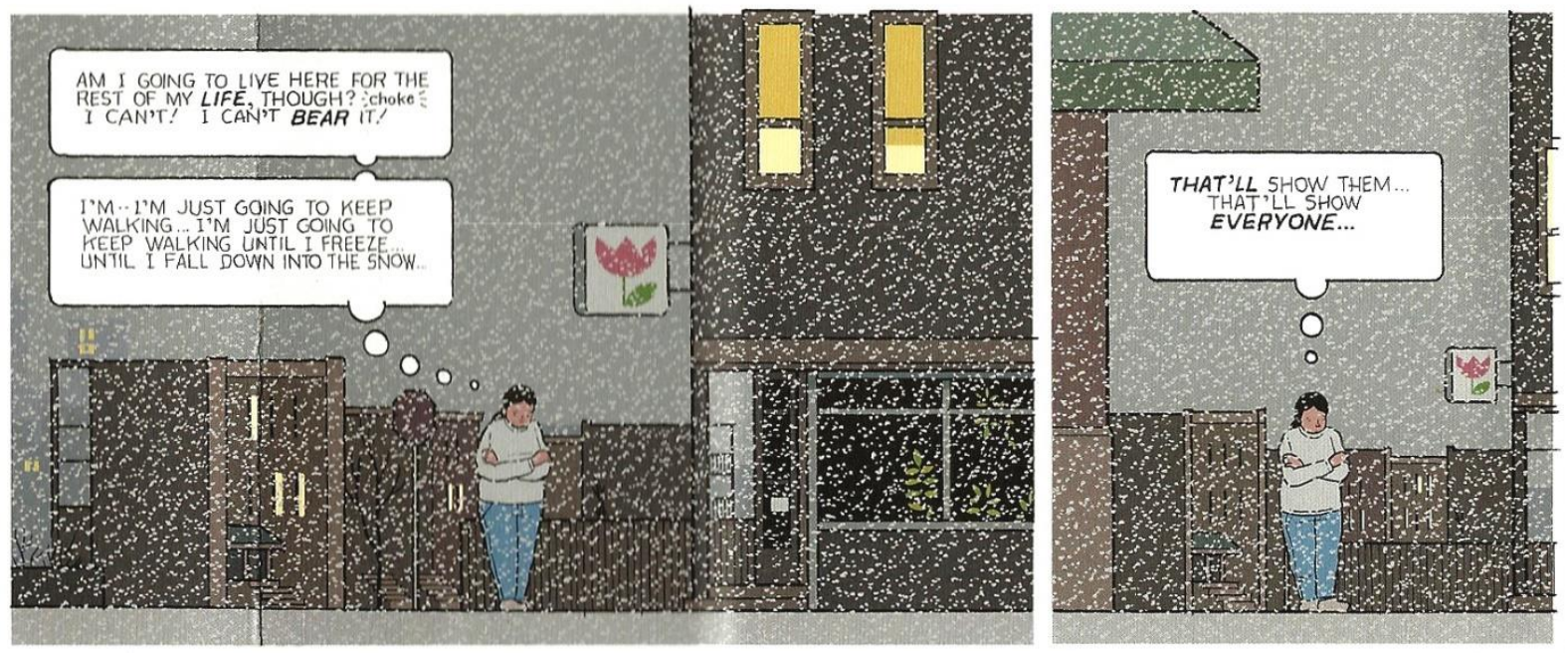

Eu vou viver aqui pelo resto da minha vida, então? *esgasgo* Não posso! Eu não posso aguentar!

Eu... Eu vou apenas continuar andando até eu congelar... Até eu cair na neve...

Isso vai mostrar pra eles... Isso vai mostrar pra todo mundo...
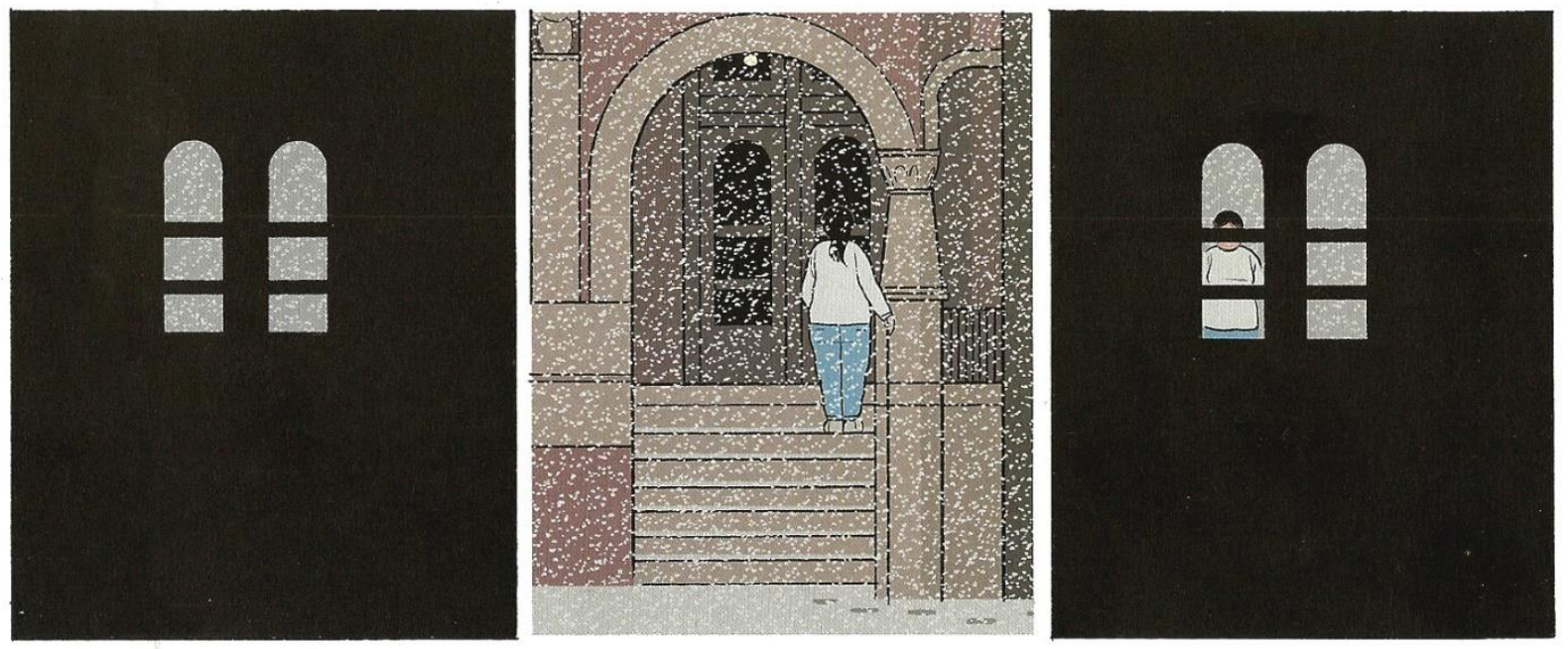
Anexo 2A: História analisada no item 2.2. Tradução nossa.

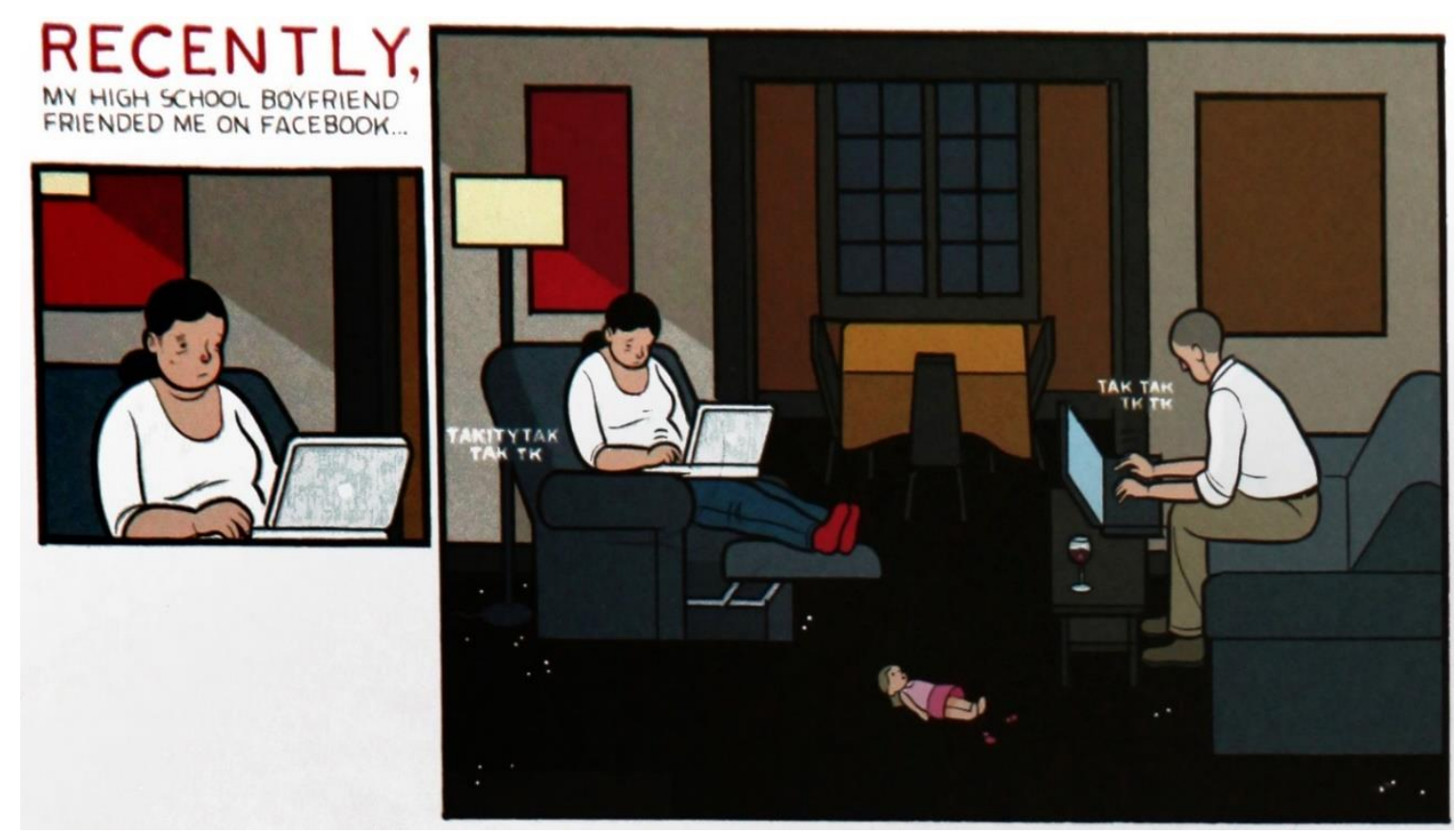

NARRAÇÃO: Recentemente, meu namorado de colégio me adicionou no Facebook...

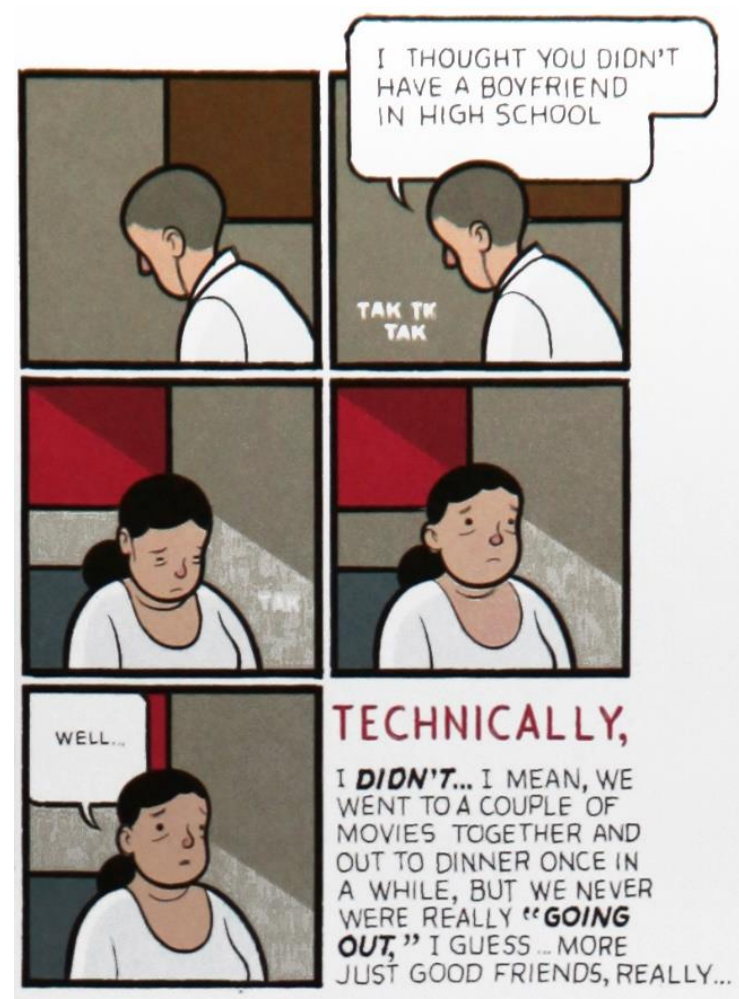

- Eu achava que você não tinha um namorado no colégio."

- Bem... 
NARRAÇÃO: Tecnicamente eu não tinha... Quer dizer, nós saímos para ver alguns filmes e para jantar de vez em quando, mas nunca "saímos" juntos, eu acho... Éramos mais bons amigos, mesmo...
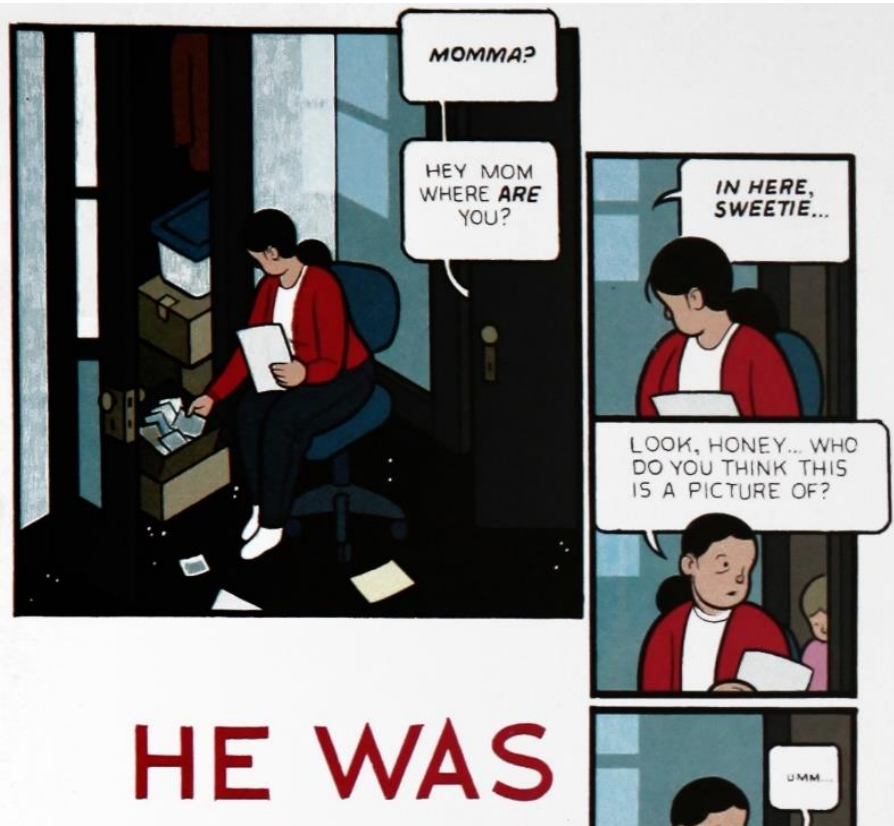

A REALLY NICE GUY, AND WE HAD A LOT IN COMMON, LIKE HATING SPORTS AND LIKING SOMERSET MAUGHAM . HE WAS JUST THE KIND OF NON-THREATENING BOY A SHY GIRL LIKE ME NEEDED IIM PRETTY SURE T WAS THE FIRST GIRL HE EVER HUNG OUT WITH, GIRL HE ENER
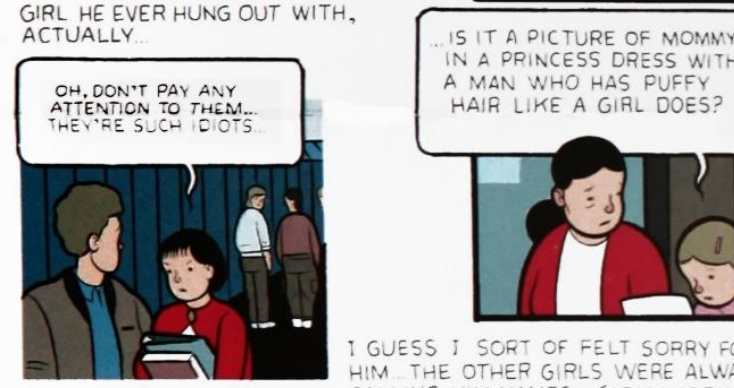
IS IT A PICTURE OF MOMMY
IN A PRINCESS DRESS WITH A MAN WHO HAS PUFEY A MAN WHO HAS PUFYY
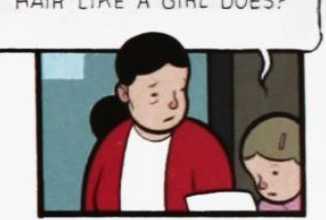

I GUESS I SORT OF FELT SORRY FOR HIM THE OTHER GIRLS WERE ALWAYS CALLING HIM NAMES (ADMITTEDLY, HE WAS PRETTY MUCH A TOTAL NERD́

- Mamãe? Ei, mamãe, cadê você?

- Aqui, querida... Olha aqui, benzinho... De quem você acha que é essa fotografia?

- É uma foto da mamãe em um vestido de princesa com um homem de cabelo fofo que nem uma menina?

NARRAÇÃO: Ele era um cara legal e tínhamos muito em comum, como odiar esportes e gostar de Somerset Maugham. Ele era o tipo de rapaz não ameaçador que uma garota tímida como eu precisava... Tenho quase certeza de que eu fui a primeira garota com quem ele saiu, na verdade...

Acho que eu sentia pena dele... As outras garotas estavam sempre chamando ele de vários nomes... (Mas eu admito que ele era um completo $n e r d . .$. 


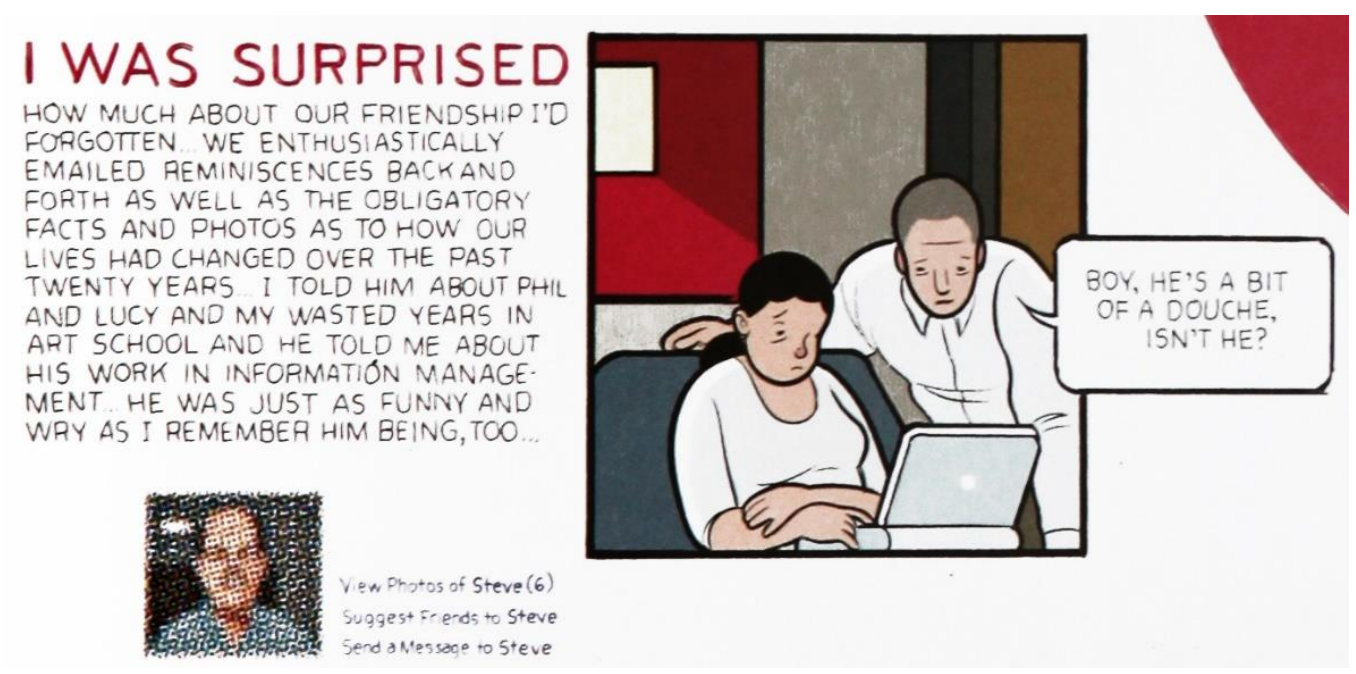

NARRAÇÃO: Eu fiquei surpresa com quanto havia esquecido da nossa amizade. Entusiasmados, nos enviamos e-mails diversas vezes relembrando o passado, além dos fatos e fotos obrigatórios sobre como nossas vidas mudaram nos últimos vinte anos. Eu contei para ele sobre os meus anos na escola de arte e ele me contou sobre o seu trabalho em gerência de informação. Ele era engraçado e sarcástico como eu lembrava, também...

- Nossa, ele é meio babaca, não? 


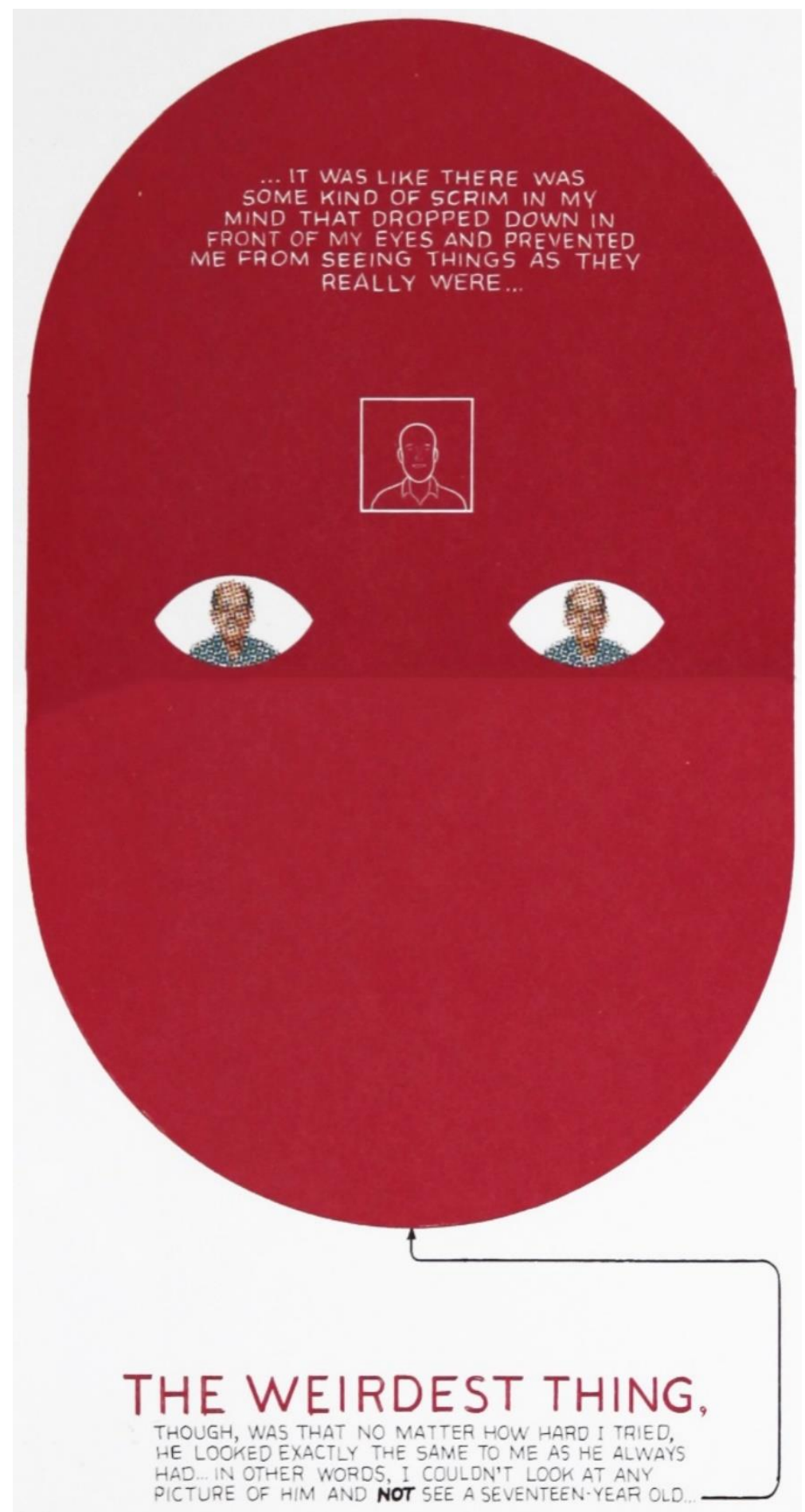

NARRAÇÃO: Era como se eu tivesse uma espécie de bloqueio na minha mente que cobria os meus olhos e me impedia de ver as coisas como elas eram...

A coisa mais estranha, no entanto, era que, não importava o quanto eu tentasse, ele parecia igual ao que ele sempre foi para mim. Em outras palavras, eu não conseguia olhar nenhuma foto dele e não ver um garoto de dezessete anos. 


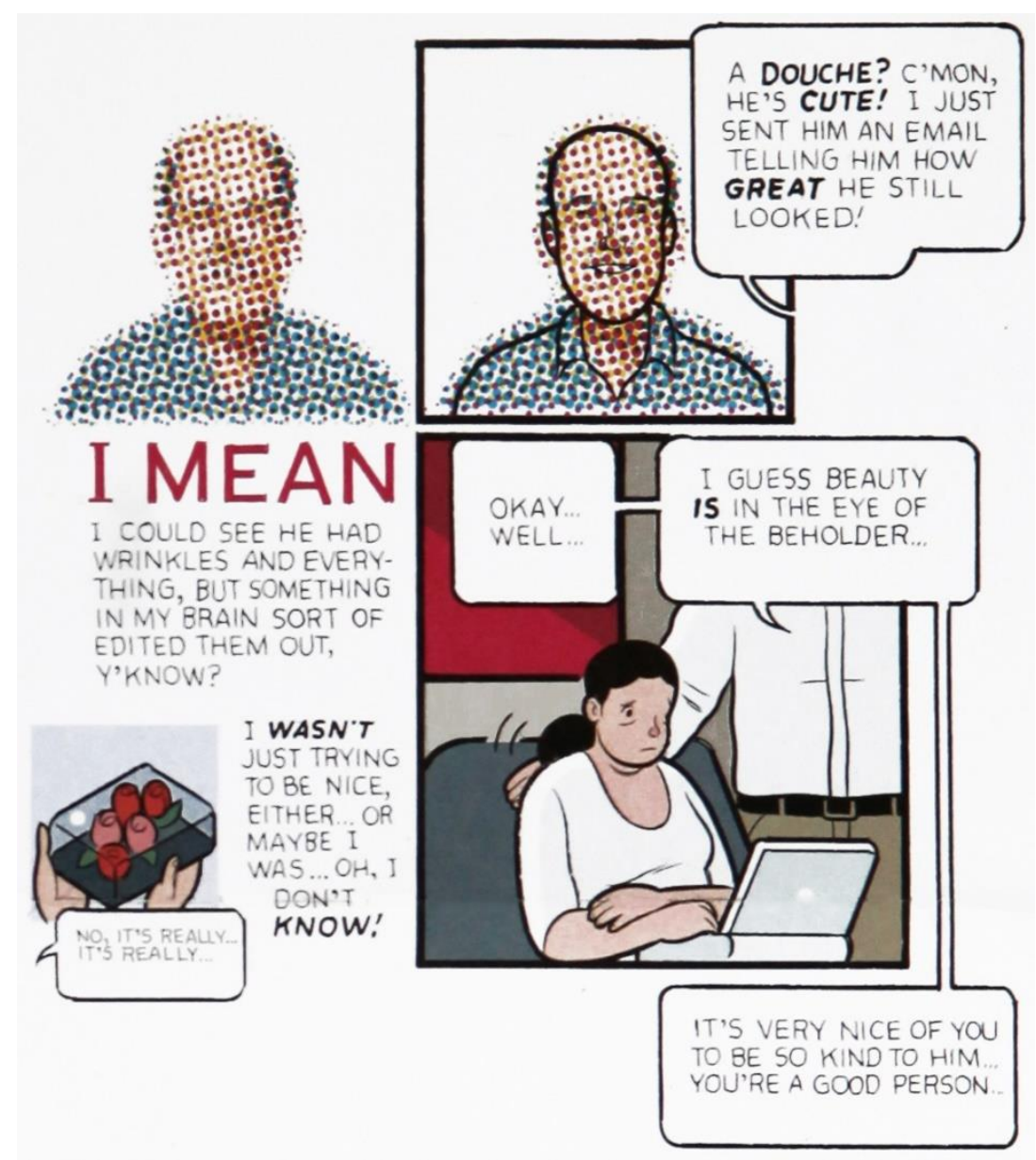

- Um babaca? Ah, vai, ele é uma graça! Eu acabei de mandar pra um e-mail falando como ele ainda estava ótimo!

NARRAÇÃO: Quer dizer, eu conseguia ver que ele tinha rugas e tudo, mas alguma coisa no meu cérebro meio que editou fora essas partes, sabe?

- Ok... Bem... Acho que a beleza está nos olhos de quem vê...

É muito bonito da sua parte ser tão gentil com ele... Você é uma boa pessoa...

NARRAÇÃO: Eu não estava tentando ser gentil, também... Ou talvez eu estava... Oh, eu não sei!

- Não, é mesmo... É mesmo... 


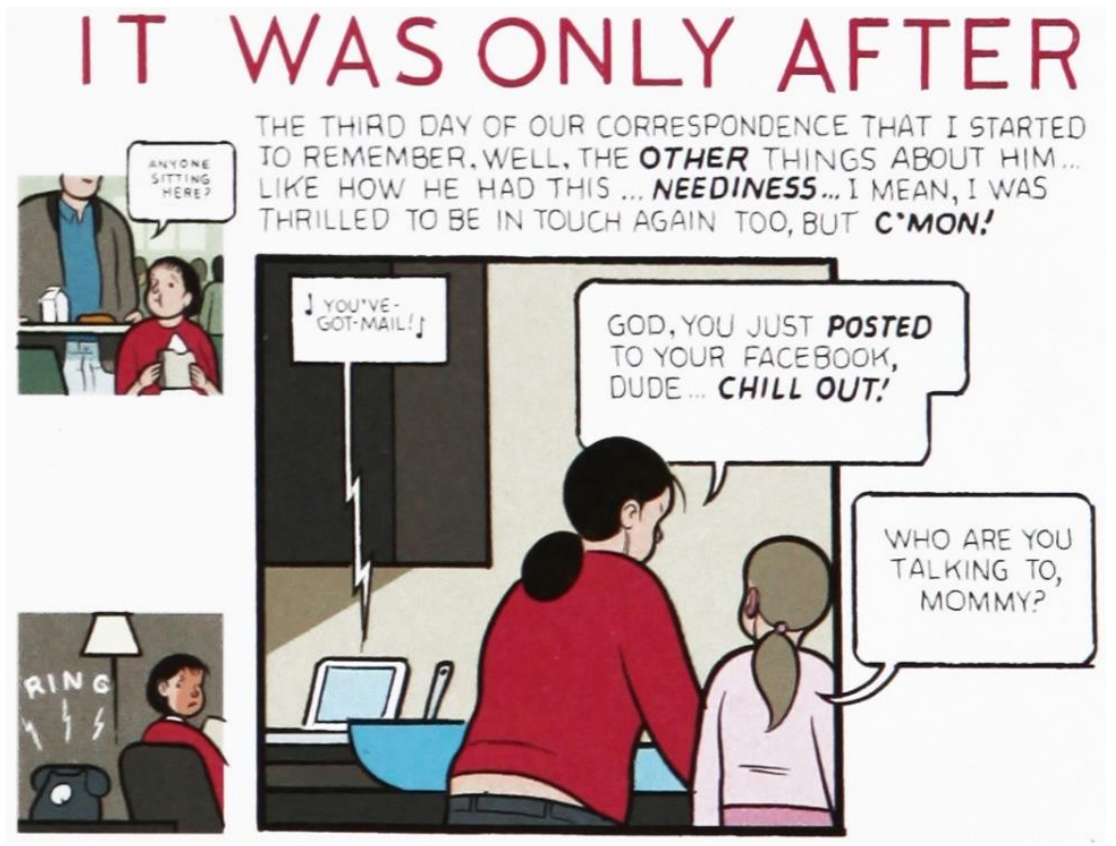

NARRAÇÃO: Foi só depois do terceiro dia da nossa correspondência que eu comecei a me lembrar, bem, das outras coisas sobre ele... Como, por exemplo, ele tinha essa... Carência... Quer dizer, eu estava animada por estarmos nos falando de novo também, mas calma lá!

\section{"VOCÊ TEM UMA NOVA MENSAGEM!"}

- Meu Deus, você acabou de postar no seu Facebook, cara... Relaxa!

- Com quem você está falando, mamãe?
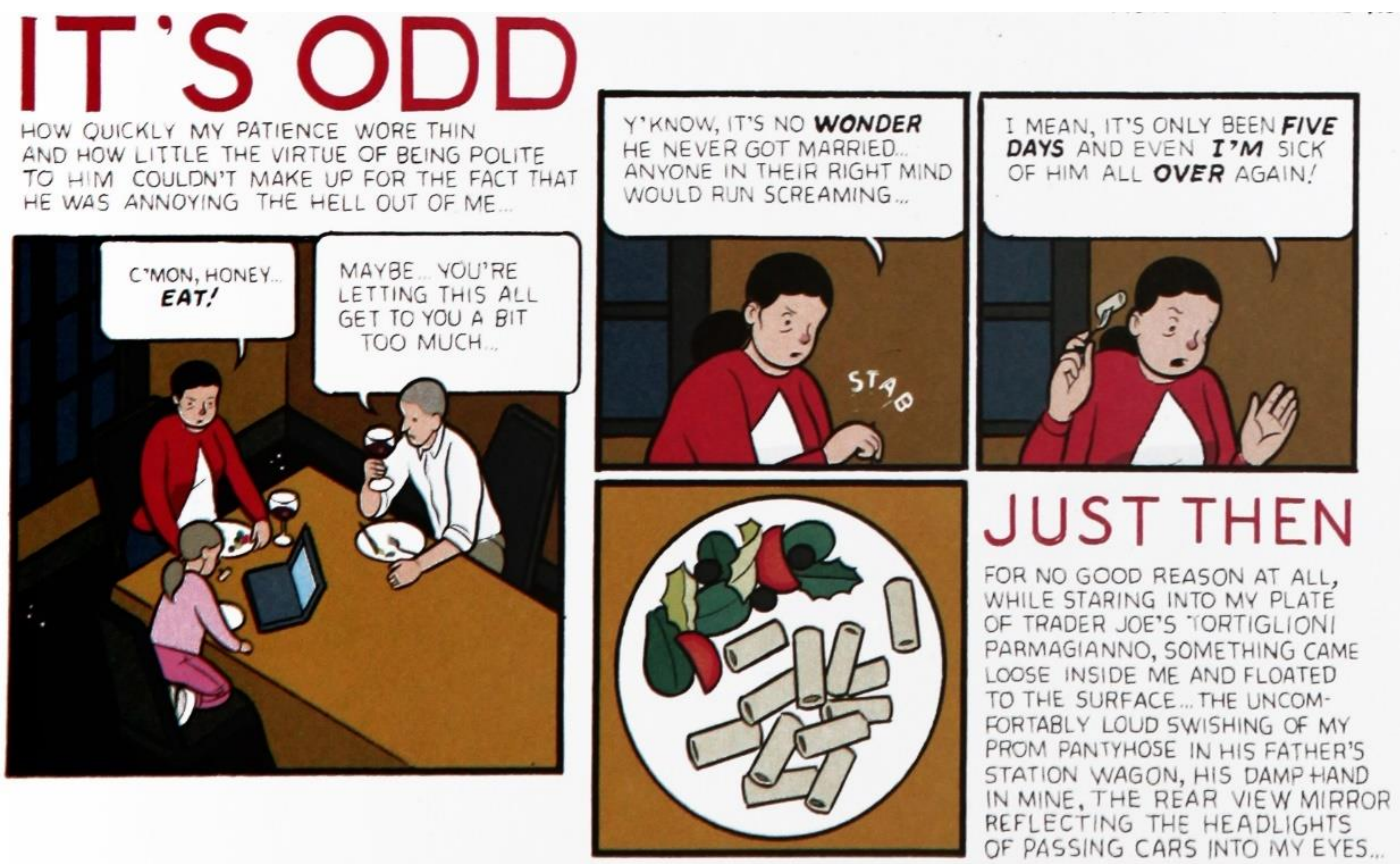
NARRAÇÃO: É estranho como minha paciência se esgotou e como a minha virtude de ser educada com ele pouco compensava o fato de que ele estava me irritando muito...

- Vamos, lá, querida... Coma!

- Talvez... Você esteja deixando isso te afetar um pouco demais...

- Sabe, não é de se espantar que ele nunca se casou... Qualquer um com juízo sairia correndo... Quer dizer, faz apenas cinco dias e até eu estou cansada dele de novo!

NARRAÇÃO: Só então, sem nenhum motivo, enquanto eu encarava meu prato de tortiglioni parmagianno do Trader Joe, alguma coisa se soltou dentro de mim e subiu à superfície... O deslizar alto e desconfortável da minha meia-calça de formatura na perua do pai dele, a sua mão suada sobre a minha, o espelho retrovisor refletindo nos meus olhos os faróis dos carros que passavam...
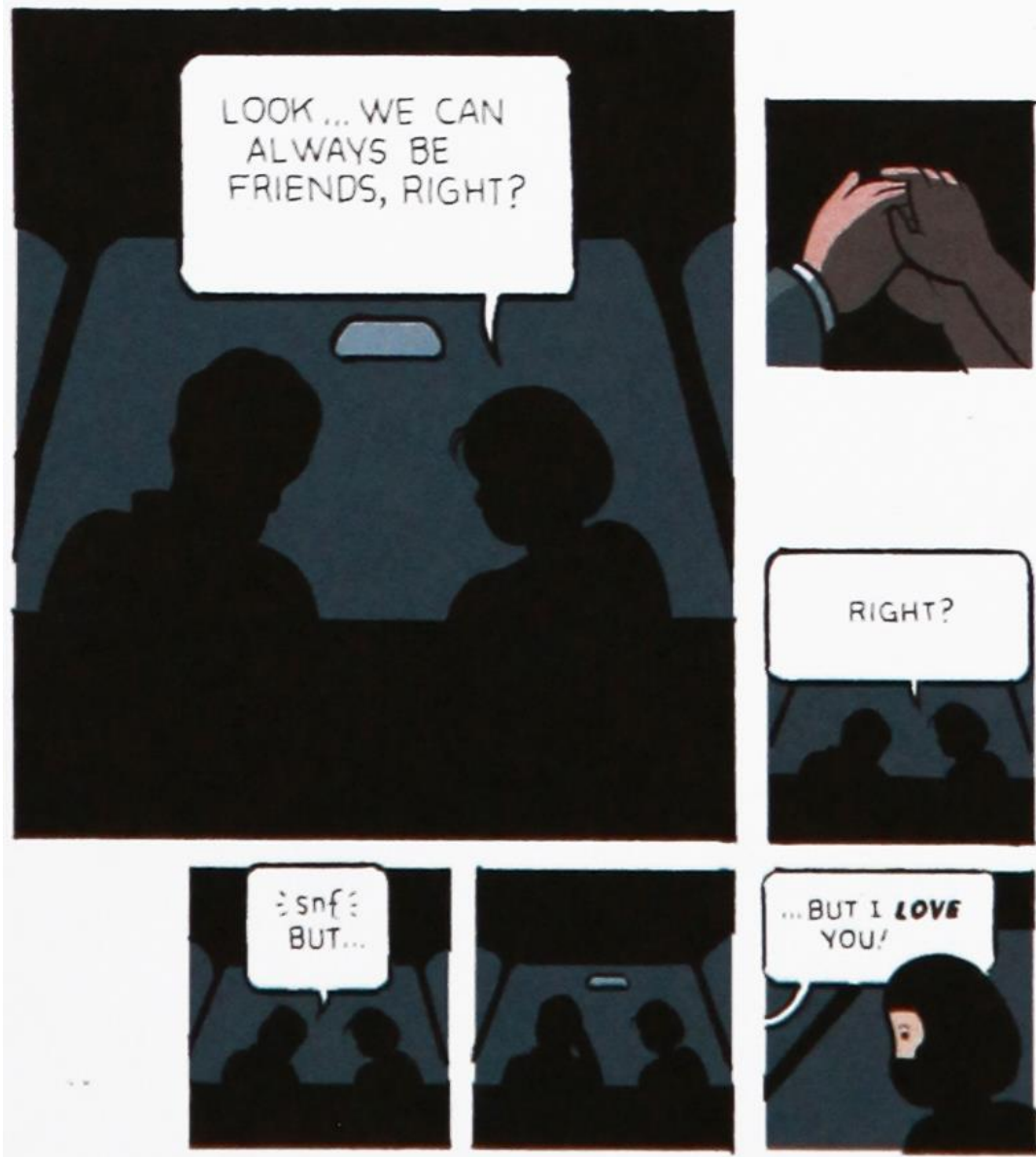

- Olha... Nós podemos sempre ser amigos, certo?

Certo?

- Mas...

... Mas eu amo você!

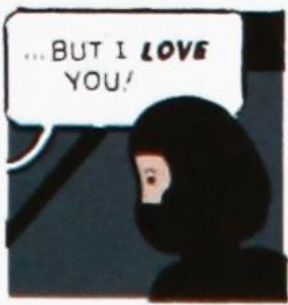



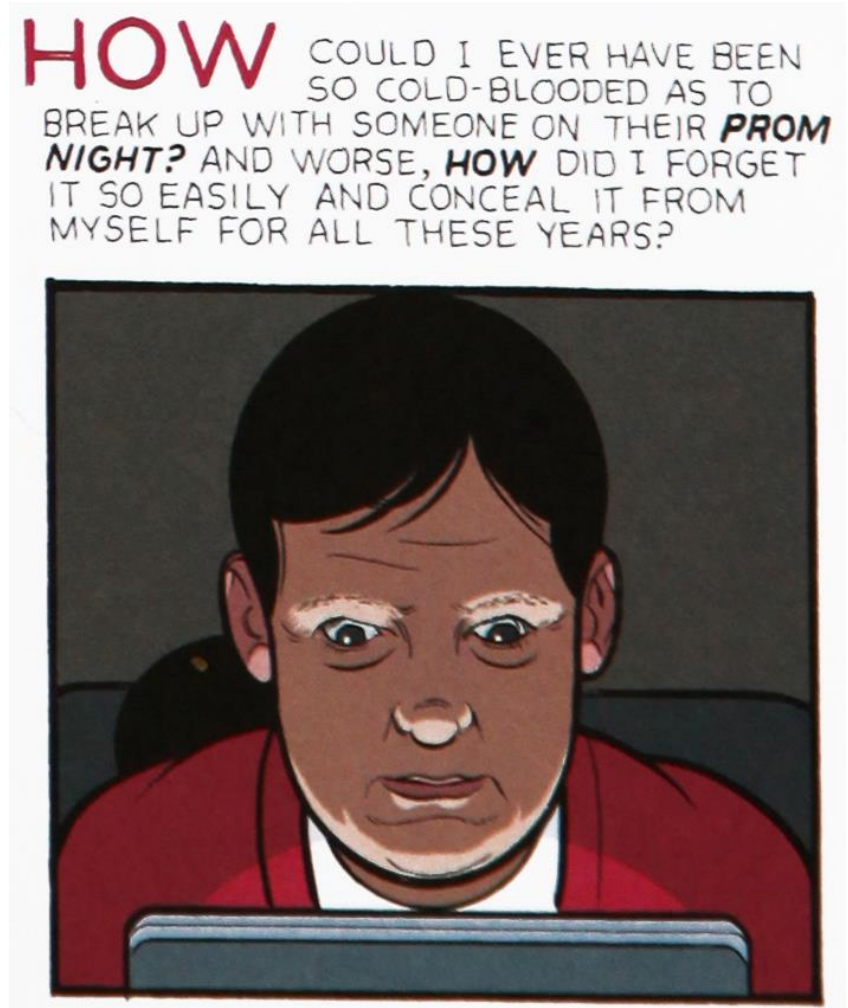

I STARTED WRITING HIM AN APOLOGY, BUT OUR CORRESPONDENCE HAD ALREAOY STARTED TO FADE, SO I ABANDONED IT... I MEAN, WHAT GOOD WOULD IT DO? HE'D ONLY USE IT AS AN EXCUSE TO START WRITING TO ME AGAIN AND THAT IS, LIKE, THE LAST THING I WANT.

NARRAÇÃO: Como eu pude ter o sangue tão frio a ponto de terminar com alguém na sua noite de formatura? E pior, como eu pude esquecer e esconder isso de mim mesma por todos esses anos?

Eu comecei a escrever para ele um pedido de desculpas, mas nossa correspondência já tinha começado a diminuir, então eu o abandonei. Quer dizer, que bem isso faria? Ele só ia usar como uma desculpa para começar a me escrever de novo e isso era, bem, a última coisa que eu queria... 
Anexo 2B: História analisada no item 2.2. Tradução nossa.

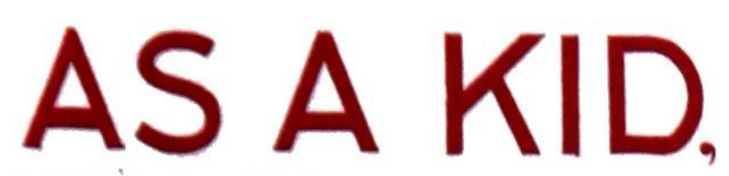

1 COULD SIT IN FRONT OF A MIRROR AND STARE AT MYSELF FOR HOURS, TRYING TO IMAGINE WHAT I'D LOOK LIKE WHEN I GREW UP..

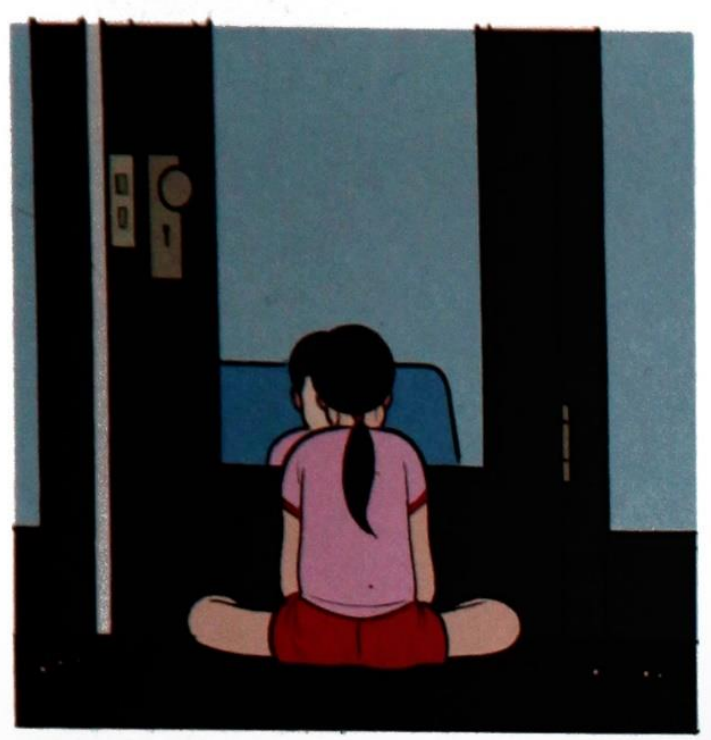

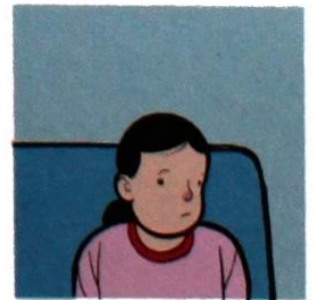

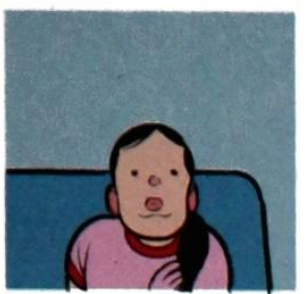

SULTRY STARLET? MYSTERIOUS WOMANOF MEANS? SERIOUS (YET PLAYFUL)FASHION MODEL

NONE OF THESE, OF COURSE, CAME TRUE. I GUESS I SIMPLY COULDN'T CONJURE "DUMPY MOM"AT THAT POINT..

MEN JUST DONT UNOERSTAND GIRLS FEEL. ABOUT THEIR BODIES AND APPEARANCES, I DON'T THINK ... IT'S NOT PART OF THEIR CULTURE.

NARRAÇÃO: Quando criança, eu era capaz de sentar na frente de um espelho e ficar me olhando por horas, tentando imaginar com o que eu me pareceria quando crescesse...

Celebridade sensual? Mulher misteriosa e rica? Modelo séria (mas divertida)? Nenhuma dessas opções se tornou realidade, claro... Eu acho que eu simplesmente não era capaz de conjurar "mãe atarracada" naquele momento...

Homens simplesmente não entendem a tremenda ansiedade que meninas sentem sobre seus corpos e aparências, eu acho... Não é parte da cultura deles... 

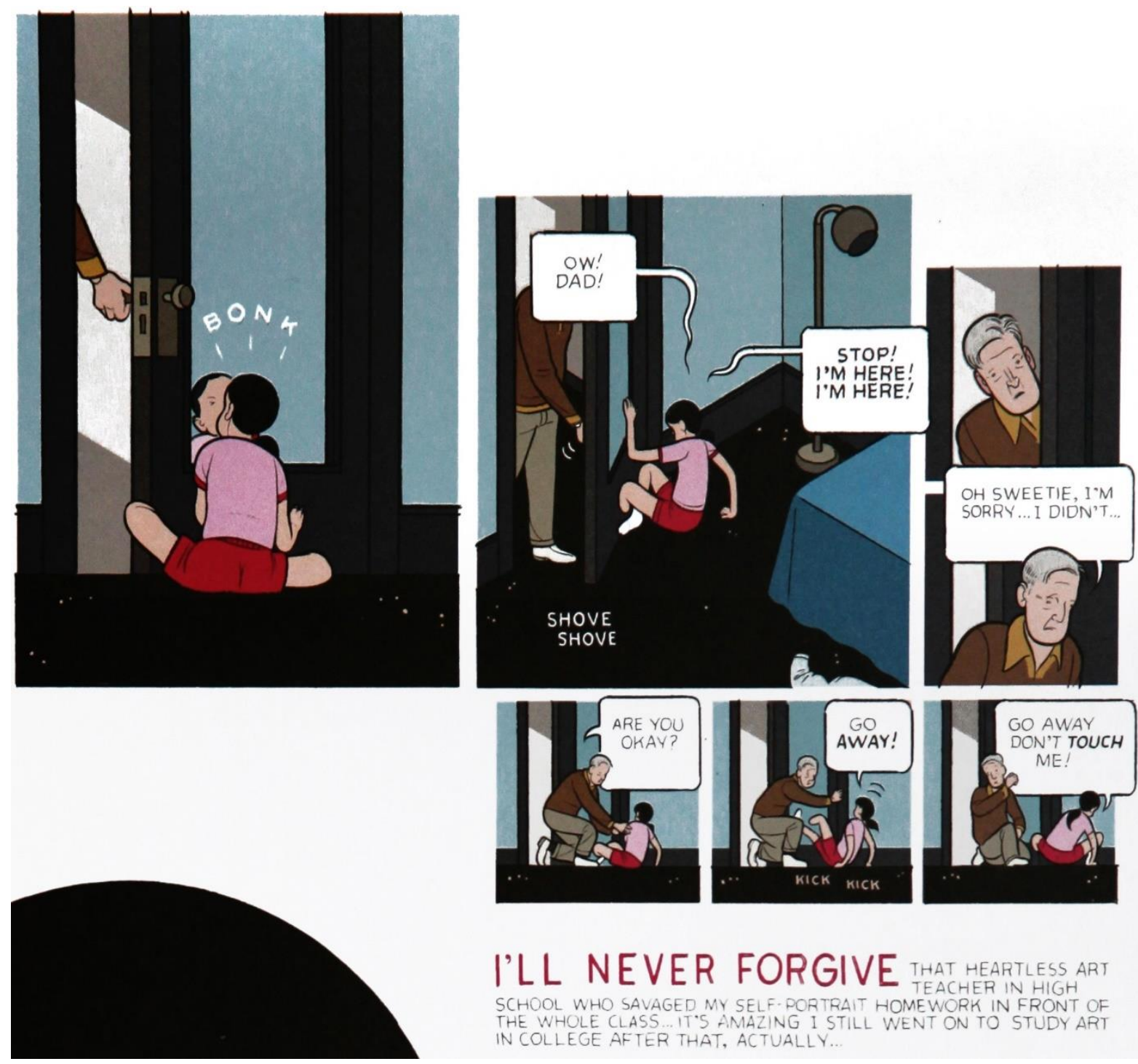

\section{I'LL NEVER FORGIVE THAT MEARTLESS ART SCHOOL WHO SAVAGED MY SELF.PORTRAIT HOMEWORK IN FRONT OF THE WHOLE CLASS ... IT'S AMAZING I STILL WENT ON TO STUDY ART IN COLLEGE AFTER THAT, ACTUALLY..}

QUADRO 6: Ai! Papai!

\section{Pára! Estou aqui! Estou aqui!}

QUADRO 8: Oh, querida, me desculpe... Eu não...

QUADRO 9: Você está bem?

\section{QUADRO 10: Vai embora!}

QUADRO 11: Vai embora, não encosta em mim!

NARRAÇÃO: Eu nunca vou perdoar aquele professor desalmado de artes no colégio que destruiu minha tarefa de autorretrato na frente da sala toda... É incrível que eu tenha ido estudar arte na faculdade, na verdade... 


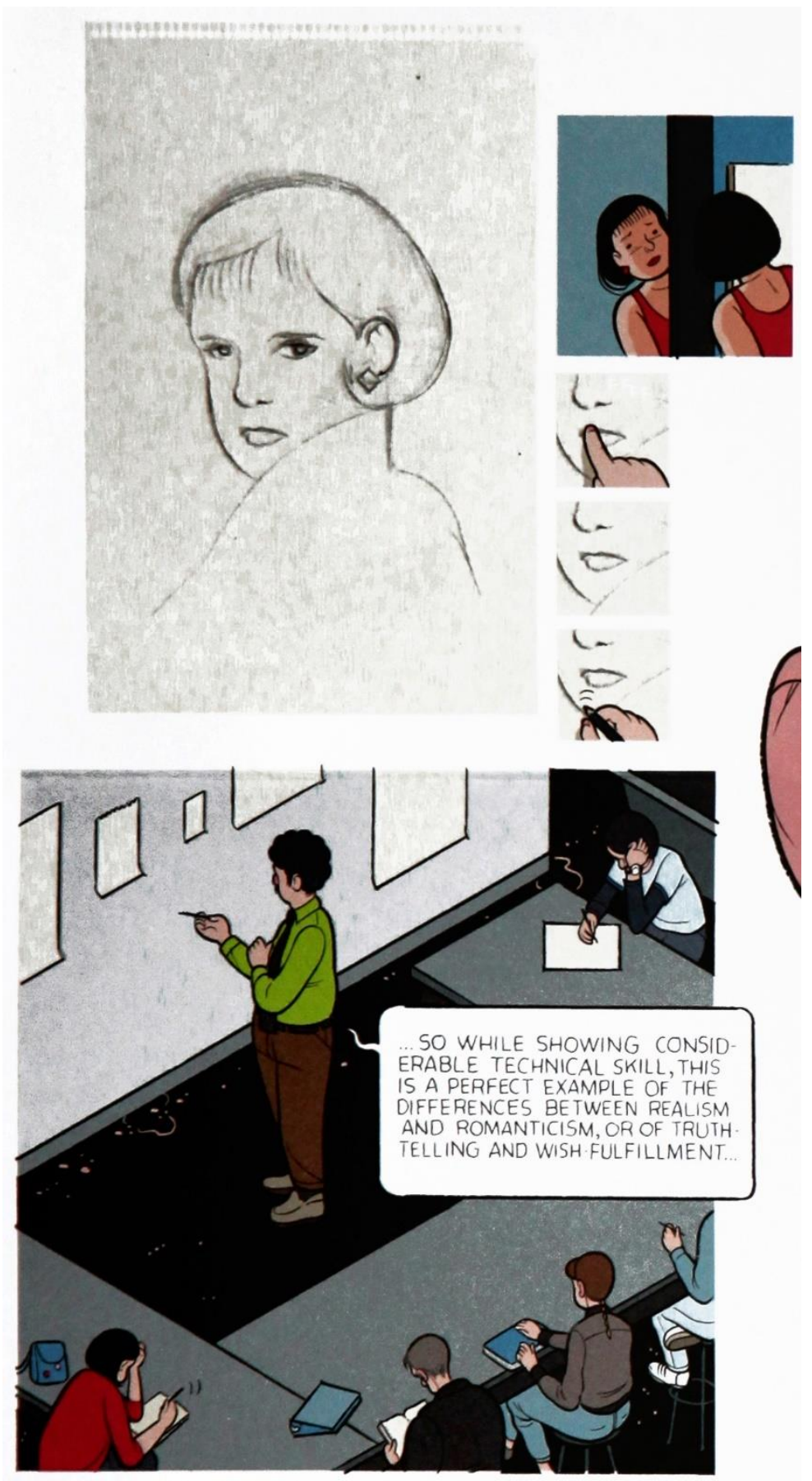

QUADRO 16: ... Então, apesar de mostrar habilidade técnica considerável, este é um perfeito exemplo entre o realismo e o romantismo, ou entre a sinceridade e a realização de desejos... 

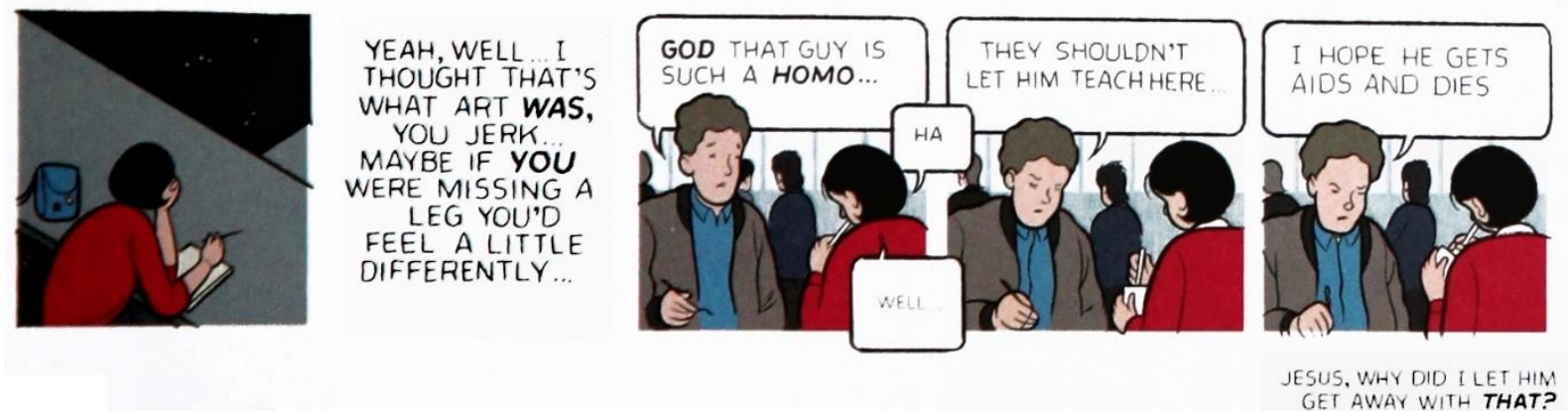

NARRAÇÃO: É, bem... Eu achei que isso era sobre isso que arte se tratava, seu idiota... Talvez se você não tivesse uma perna, se sentiria diferente a respeito disso...

- Deus, aquele cara é uma bicha...

- Haha...

Bem...

- Não deviam deixá-lo ensinar aqui...

Espero que ele pegue AIDS e morra.

NARRAÇÃO: Jesus, como eu deixei ele falar aquilo?
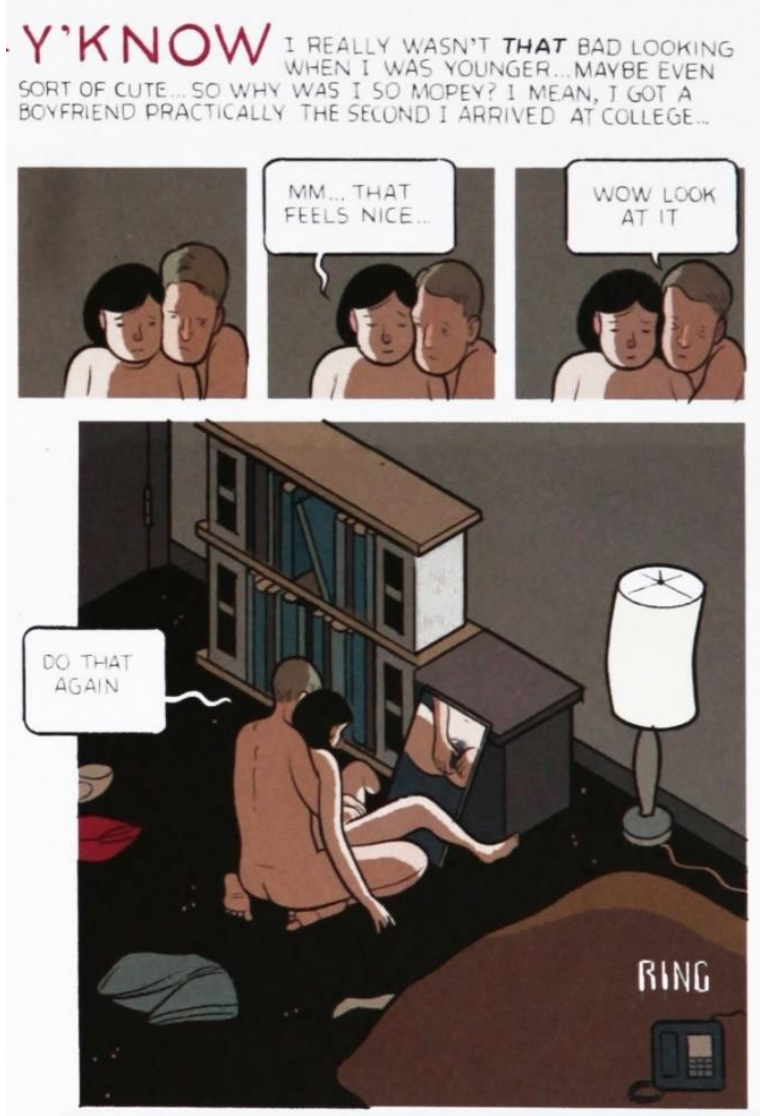

MAYBE I THOUGHT I DIDN T DESERVE IT, OR SOMETHING GOD THAT ALL SEEMS LIKE A MILLION YEARS AGO NOW... 
NARRAÇÃO: Sabe, eu realmente não era tão feia assim quando mais nova... Talvez fosse até bonitinha... Então porque eu era tão cabisbaixa? Quer dizer, eu tive um namorado praticamente no segundo em que entrei na faculdade...

- Mmm... Isso é bom...

- Nossa, olha isso.

- Faz aquilo de novo...

NARRAÇÃO: Talvez eu achasse que eu não merecesse aquilo ou coisa parecida... Deus, tudo parece que faz milhões de anos...
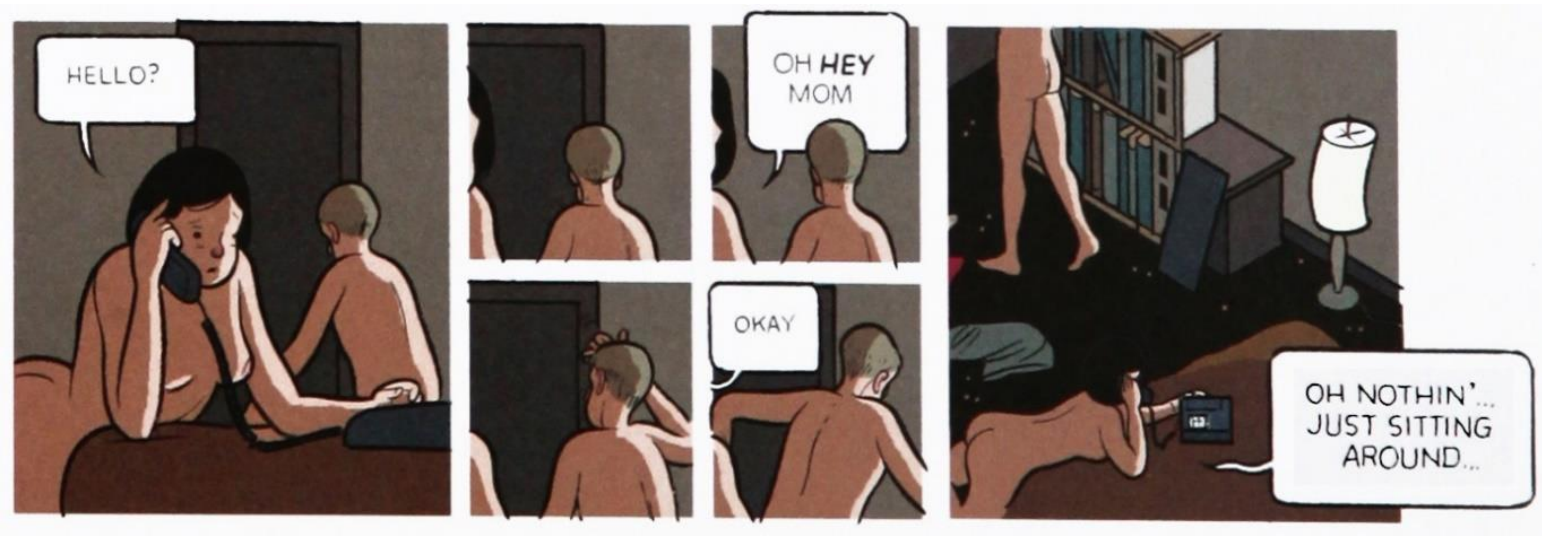

- Alô?

Ah, oi, mãe.

Ok.

Ah, nada... Só passando o tempo... 


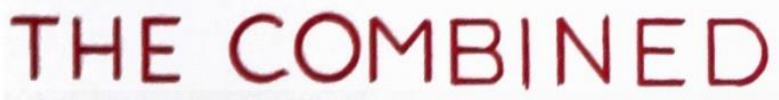

FEATURES OF MY MOTHER AND FATHER, STARING BACK AT ME ALL THESE YEARS SUPPOSEDLY...

MAYBE A LITTLE OF MY MOM AROUND THE EYES AND

NOSE ... BUT MY DAD? I DIDN'T SEE IT FOR A WHILE, I EVEN STARTED TO WONDER IF I WAS ADOPTED

THAT'S WHAT MY FIRST REAL BOYFRIEND THOUGHT

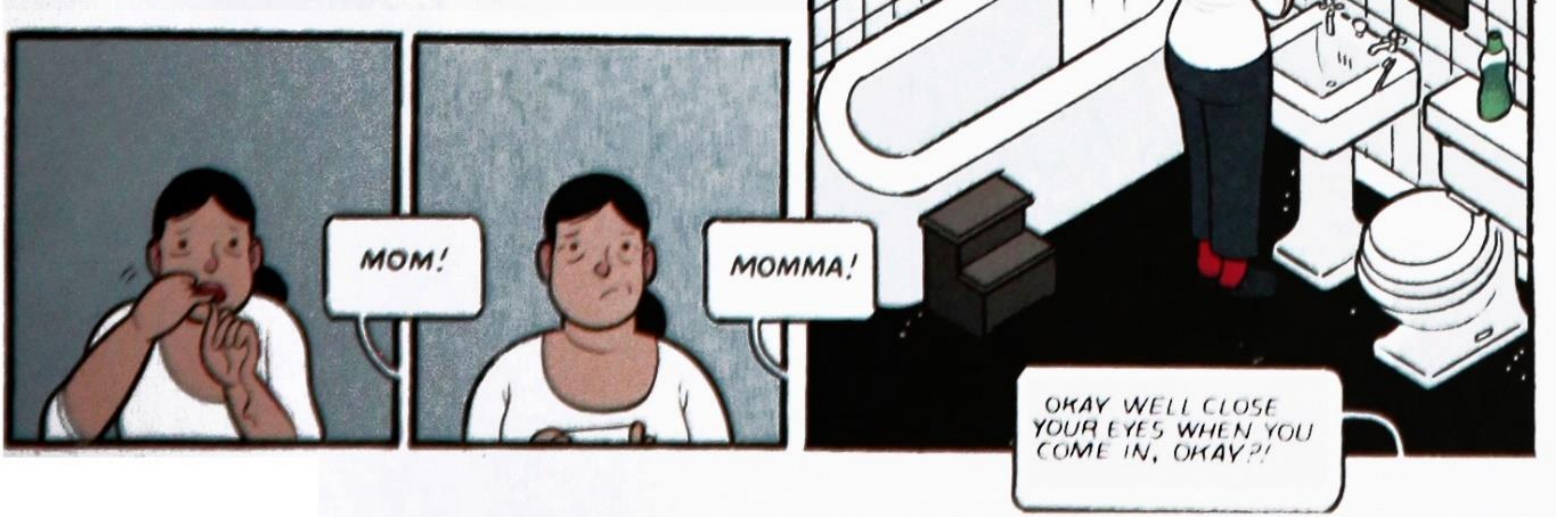

NARRAÇÃO: Os traços combinados da minha mãe e do meu pai, me encarando de volta depois de todos esses anos... Supostamente... Talvez um pouco da minha mãe em torno dos olhos e nariz... Mas o meu pai? Eu não conseguia ver... Durante um tempo, eu até comecei a achar que era adotada... Era isso que meu primeiro namorado de verdade achava...

- Mãe! Mamãe!

- Já vou em um segundo, querida!

- Ok, bem, fecha os olhos quando vier, ok?
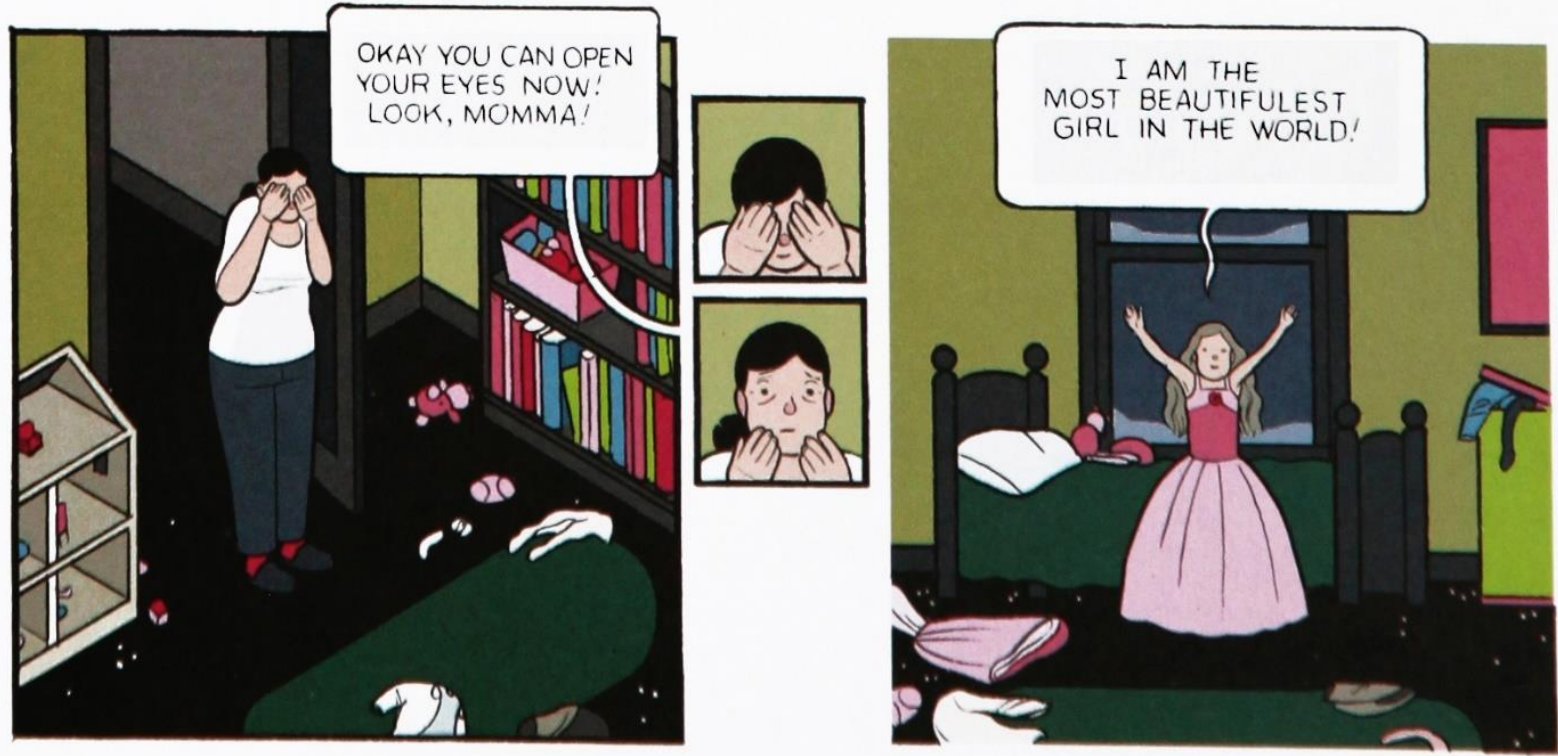

- Ok, você pode abrir os olhos agora, mamãe!

Eu sou a garota mais lindíssima do mundo! 